Florida International University FIU Digital Commons

$11-14-2002$

\title{
Relectura del discurso novomundista de Alejo Carpentier y Abel Posse en el contexto de la nueva novela histórica
}

Francisco Eduardo Porrata

Florida International University, fporra01@fiu.edu

DOI: $10.25148 /$ etd.FI08081537

Follow this and additional works at: https://digitalcommons.fiu.edu/etd

\section{Recommended Citation}

Porrata, Francisco Eduardo, "Relectura del discurso novomundista de Alejo Carpentier y Abel Posse en el contexto de la nueva novela histórica" (2002). FIU Electronic Theses and Dissertations. 40.

https://digitalcommons.fiu.edu/etd/40 


\title{
FLORIDA INTERNATIONAL UNIVERSITY
}

\author{
Miami, Florida
}

\section{RELECTURA DEL DISCURSO NOVOMUNDISTA DE ALEJO CARPENTIER Y ABEL POSSE EN EL CONTEXTO DE LA NUEVA NOVELA HISTÓRICA}

A dissertation submitted in partial fulfillment of the

$$
\begin{aligned}
& \text { requirements for the degree of } \\
& \text { DOCTOR OF PHILOSOPHY }
\end{aligned}
$$

in

SPANISH

by

Francisco Eduardo Porrata 

To: Dean Arthur W. Herriott

College of Arts and Sciences

This dissertation, written by Francisco Eduardo Porrata, and entitled, Relectura del discurso novomundista de Alejo Carpentier y Abel Posse en el contexto de la nueva novela histórica, having been approved in respect to style and intellectual content, is referred to you for judgment.

We have read this dissertation and recommend that it be approved.

Dr. Reinaldo Sánchez

Dr. Florence Yudin

Dr. Santiago Juan-Navarro, Major Professor

Date of Defense: November 14, 2002

The dissertation of Francisco Eduardo Porrata is approved.

Dean Arthur W. Herriott College of Arts and Sciences

Dean Douglas Wartzok University Graduate School

Florida International University, 2002 
(c) Copyright 2002 by Francisco Eduardo Porrata

All rights reserved. 


\section{DEDICATORIA}

Dedico esta tesis a mi padre, a su recuerdo y presencia, quien supo cultivar en mí desde niño el amor por los libros. A mi madre por darme su aliento en la búsqueda de nuevos horizontes. A Alexis Solís por tantos años de apoyo incondicional. A la memoria de Guillermo Hernández y a todos aquellos jóvenes que un día soñamos juntos y fundamos la Casa de la Cultura Cubana en Florida International University. 


\section{AGRADECIMIENTOS}

Quiero expresar mi gratitud al Dr. Reinaldo Sánchez por compartir conmigo durante tantos años sus conocimientos. A él debo gran parte de mi formación académica. A la Dra. Florence Yudin por enseñarme a leer con amor y dedicación la poseía y el teatro. Al Dr. Santiago Juan-Navarro por iniciarme en el estudio de la nueva novela histórica y la teoría literaria, así como por su valiosa ayuda en el proceso investigativo y de redacción de esta tesis. A todos aquellos profesores, maestros y compañeros de clases que de una manera u otra dejaron una huella hermosa en mi formación como ser humano. 


\begin{abstract}
OF THE DISSERTATION
RELECTURA DEL DISCURSO NOVOMUNDISTA DE ALEJO CARPENTIER Y ABEL POSSE EN EL CONTEXTO DE LA NUEVA NOVELA HISTÓRICA by
\end{abstract}

Francisco Eduardo Porrata

Florida Internacional University, 2002

Miami, Florida

Profesor Santiago Juan-Navarro, Major Professor

The purpose of this dissertation was to analyze the narrative works of Alejo Carpentier and Abel Posse within the context of the new Latin American historical novel that revises the Old World-New World Encounter. Focusing on El arpa y la sombra and Los perros del paraíso, the dissertation studied the particular manner in which Latin American novelists, and particularly Alejo Carpentier and Abel Posse, approach and question traditional historiography. The research also compared different novels to identify various trends within the new historical novel that rewrites the foundational period of Latin American literature.

This study considered the theories of the new historical novel as proposed by critics such as Seymour Menton, Fernando de Aínsa, Linda Hutcheon, and Brian MacHale. The new novel was examined within the frameworks of postmodern literary and historiographic theories. The study also contemplated the philosophical views that have influenced 
postmodern thought, and, especially, the ideas of Nietzsche, Heidegger, Lyotard, Harbermas, and Foucault.

Research showed two major trends within the new Latin American historical novel. In the case of the first trend, initiated by Alejo Carpentier in 1949 with El reino de este mundo, the novelist's approach is founded on historicism and factual rigor. The second trend, initiated by Reinaldo Arenas with El mundo alucinante in 1969, is marked by irreverence, parody, irony, and carnavalization. Characterized by intertextuality, dialogism, and anachronism, novels such as Carpentier's El arpa y la sombra and Posse's Los perros del paraíso, undermine the values and beliefs instituted by the traditional historiographic paradigm and the discourse of power. 


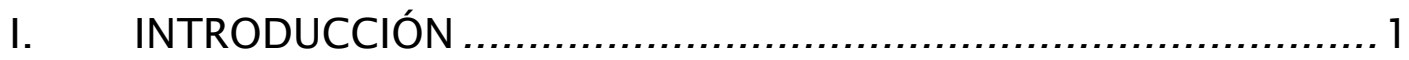

II. APUNTES PARA UNA TEORÍA DE LA NUEVA NOVELA

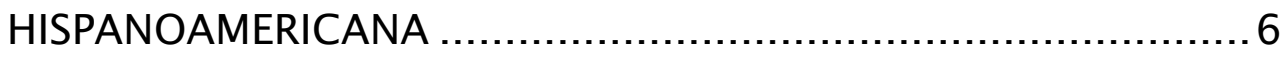

La novela histórica en Hispanoamérica ................................ 6

La nueva novela histórica y el pensamiento postmodernista ...25

III. LA NUEVA NOVELA HISTÓRICA NOVOMUNDISTA EN HISPANOAMÉRICA .................................................... 52

El descubrimiento y la conquista en la novela Hispanoamericana ....................................................... 52

Colón: entre la controversia y la especulación.........................55 55 Lope de Aguirre: El conquistador rebelde ...........................68

Otras (sub)versiones del descubrimiento y la conquista ..........77

IV. LA NUEVA NOVELA HISTÓRICA DE ALEJO CARPENTIER .............88

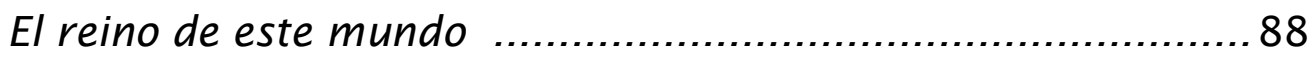

El siglo de las luces ......................................................... 102

V. LA NUEVA NOVELA DE HISTÓRICA DE ABEL POSSE.................126

El Aguire histórico .......................................................... 126 
El Aguirre literario …....................................................... 127

El Aguirre de Posse: Daimón ............................................... 128

El Cabeza de Vaca histórico .............................................. 145

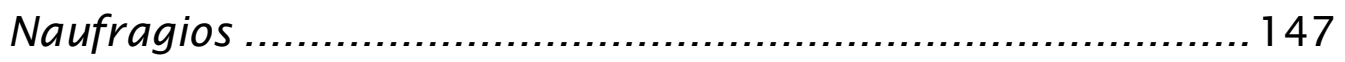

El largo atardecer del caminante: una reescritura

postmoderna de Naufragios ............................................ 148

VI. EI ARPA Y LA SOMBRA ..................................................... 163

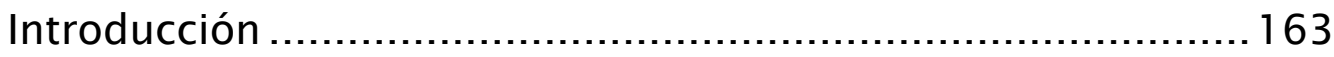

El Mastai Ferretti histórico (Pío IX) ....................................... 172

La desmitificación de Colón ................................................. 174

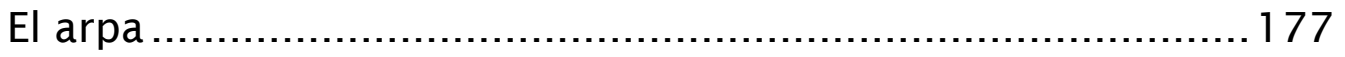

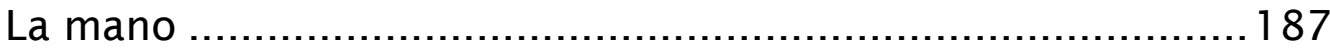

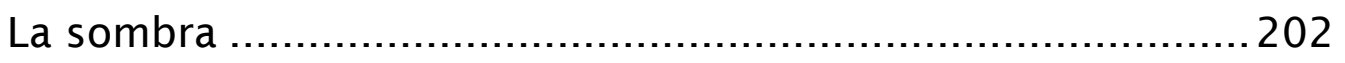

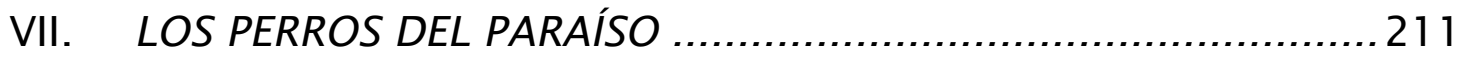

Los perros del paraíso: una novela novomundista..................21 1

Procedimientos para la reescritura de la historia....................222

Discurso desacralizador de Colón y demás

protagonistas de la conquista...........................................240

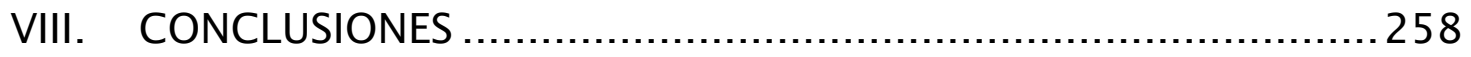




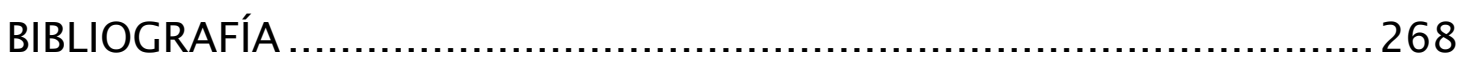

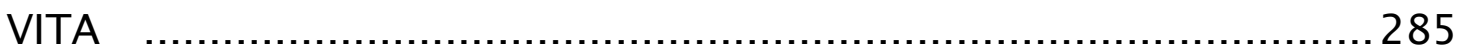




\section{Introducción}

El propósito de esta tesis consiste en investigar la obra de Alejo Carpentier y Abel Posse dentro del contexto de la nueva novela histórica hispanoamericana ambientada en el período del encuentro y la conquista. El discurso historiográfico tradicional ha ofrecido una visión eurocéntrica sobre la conquista y el encuentro del Viejo y el Nuevo Mundo, así como de sus protagonistas. En los últimos años los novelistas hispanoamericanos han demostrado un marcado interés en el tema del encuentro, la conquista y el período colonial en América. En esta tesis se estudia en qué medida los novelistas hispanoamericanos, especialmente Alejo Carpentier y Abel Posse, se aproximan al discurso historiográfico oficial. También se ha tenido presente en la investigación cómo ambos autores mitifican o desconstruyen figuras y sucesos del registro histórico y otras veces rescatan personajes olvidados o "marginados" por el discurso canónico de la historia.

El tema es de suma importancia, ya que en las obras estudiadas, enmarcadas dentro de la nueva novela histórica, podemos encontrar una nueva visión de la historia que aspira a cubrir los "vacíos" existentes en el discurso oficial. La investigación ha permitido ampliar y profundizar la forma en que la nueva novela histórica reescribe el período fundacional de la literatura hispanoamericana. 
Para realizar la labor investigativa se ha tenido en consideración la bibliografía existente sobre el tema. Se han considerado los estudios sobre la nueva novela histórica de críticos tales como Seymour Menton y Fernando Aínsa. De igual manera, se han estudiado los postulados postmodernistas de Linda Hutcheon y Brian MacHale, así como la filosofía de la historia de Keith Jenkins y Hayden White. También se han tenido presente las ideas de pensadores que han influido en el pensamiento postmodernista como Nietzsche, Heidegger, Lyotard, Habermas y Foucault. Ha sido de gran utilidad el libro Archival Reflections: Postmodern Fiction of the Americas (Self-Reflexivity, Historical Revisionism, Utopia), del director de tesis, así como la antología A Twice Told Tale: Reinventing the Old World-New World Encounter in Iberian/Iberian American Literature and Film, co-editada por Santiago Juan-Navarro y Theodore R. Young. Consideramos que, a pesar del interés por la crítica sobre la nueva novela histórica, existía la necesidad de cubrir cierto espacio que necesitaba de un estudio detallado.

A través de una relectura del discurso historiográfico de Alejo Carpentier y Abel Posse en el contexto de la nueva novela histórica hispanoamericana y del análisis de esta última en relación con el tema del encuentro y la conquista, aspiramos a cubrir el vacío existente sobre el tema. A su vez el trabajo comparativo ha permitido establecer la 
existencia de una nueva tendencia dentro de la nueva novela histórica que reescribe el período fundacional de la literatura hispanoamericana.

El primer capítulo ofrece un estudio panorámico de la novela histórica desde las primeras manifestaciones en el siglo XIX hasta su transformación en el siglo XX, dentro de lo que ha venido en llamarse la nueva novela histórica hispanoamericana. En este capítulo se estudian también los postulados del Nuevo Historicismo y de aquellos que han influido en la formación del pensamiento postmodernista internacional. Se ha tenido presente además los rasgos paradigmáticos de lo que Seymour Menton y Fernando Aínsa califican como nueva novela historiográfica y ficción postmodernista respectivamente.

El segundo capítulo está dedicado al estudio de la nueva novela histórica centrada en el tema del encuentro y la conquista teniendo en cuenta que en los últimos años ha incrementado el interés histórico de los novelistas hispanoamericanos por el tema. Este interés y las actuales estrategias interpretativas de metadiscursos (post)estructuralistas han producido una serie de novelas que podríamos llamar del "redescubrimiento".

Los capítulos tercero y cuarto exploran las obras de Alejo Carpentier y Abel Posse desde la perspectiva de la nueva novela histórica. En el caso de Alejo Carpentier revisamos El reino de este mundo de 1949; novela que Seymour Menton sugiere como el punto de partida de la 
nueva novela histórica hispanoamericana y El siglo de las luces, considerada por algunos críticos como una de las novelas paradigmáticas de una primera fase de la nueva novela histórica hispanoamericana. Ambas novelas coinciden en la recreación de una época: inicios de la Revolución Francesa hasta poco después de la Revolución de Haití. Ambas novelas también recrean y rescatan personajes históricos prácticamente olvidados o "marginados" por la historia oficial.

De Abel Posse, uno de los escritores hispanoamericanos que mayor interés ha mostrado por el tema del encuentro, la conquista y el período colonial, estudiamos Daimón, obra en la que, a partir de la figura de Lope de Aguirre, Posse reconstruye cinco siglos de historia hispanoamericana. Analizamos también El largo atardecer del caminante, donde se recrea el destino de uno de los hombres más paradójicos y extraordinarios de la conquista española, Álvar Nuñez Cabeza de Vaca, considerado por algunos como el verdadero descubridor de los Estados Unidos. Daimón y El largo atardecer del caminante conforman junto a Los perros del paraíso la llamada trilogía de la Conquista del novelista argentino.

Los capítulos quinto y sexto están dedicados a un análisis de $E L$ arpa y la sombra de Alejo Carpentier y Los perros del paraíso de Abel Posse respectivamente. Se han tenido en cuenta los personajes históricos recreados, los narradores, elementos intertextuales, anacronismos, superposición de espacios temporales, así como algunos conceptos 
bajtinianos tales como el dialogismo, la polifonía, la parodia y el carnaval. También se han analizado el discurso y la visión histórica que se desprende de ambos textos.

Resumiendo, podemos decir que en esta tesis se estudian las obras de Alejo Carpentier y Abel Posse en el contexto de la nueva novela histórica hispanoamericana. Partiendo de los estudios de Seymour Menton, Fernando Aínsa, Linda Hutcheon y Brian McHale, entre otros, se teoriza sobre la nueva novela histórica en el contexto de las teorías del postmodernismo literario e historiográfico. Se revisan, dentro de la nueva novela histórica, aquellas novelas centradas en el tema del encuentro y la conquista, analizándose con especial detenimiento El arpa y la sombra y Los perros de paraíso. La tesis en su conjunto es un trabajo comparativo entre diferentes novelas novomundistas que permite establecer la existencia de diversas tendencias dentro de la nueva novela histórica que reescribe el período fundacional de la literatura hispanoamericana. 


\section{Primer capítulo: Apuntes para una teoría de la nueva novela histórica hispanoamericana}

\section{LA NOVELA HISTÓRICA EN HISPANOAMÉRICA}

Las primeras manifestaciones de lo que pudiéramos llamar novelas históricas tuvieron lugar en el siglo XIX dentro del marco de la estética romántica y realista. Con el advenimiento del siglo XX la novela histórica evoluciona en Hispanoamérica dentro de la estética modernista que trajo, entre otras consecuencias, una revitalización de la lengua española. A medida que fueron surgiendo las nuevas naciones americanas la novela histórica también incursiona dentro del criollismo de la época. Pero es en el inicio de la segunda mitad de siglo XX cuando la novela histórica inicia una gran transformación, con la publicación de la novela El reino de este mundo (1949) de Alejo Carpentier, para convertirse en lo que ha venido en llamarse la "nueva novela histórica".'

La primera novela histórica que se conoce en Hispanoamérica es Jicoténcalt, de autor anónimo. ${ }^{2}$ Fue publicada en 1826 y por más de un siglo se mantuvo prácticamente olvidada hasta que en el año 1964 se realizó una segunda edición. Novela de estilo romántico, idealizadora del, indígena, nos narra la conquista de México por Hernán Cortés y la ayuda que los conquistadores recibieron de los aborígenes tlaxcaltecas en su lucha para derrotar al imperio azteca. El contenido y el estilo, así como el 
lugar, fecha y circunstancias de su publicación indican que esta novela fue una expresión americana de emancipación en el período de lucha de las colonias españolas por alcanzar su independencia. Otras novelas históricas, como Netzula (1832) de José María Lafragua, Guatimozín (1846) de Gertrudis Gómez de Avellaneda, y Los mártires de Anáhuac (1870) de Eligio Ancona, recrearon también la conquista española y la idealización del indígena como expresión del romanticismo hispanoamericano.

La novela histórica romántica concentra la historia en los personajes, está escrita a la manera tradicional, es decir, en orden cronológico, carece de objetivismo y nos da una visión idealizada de la historia, usando como fuente el registro histórico tradicional. Los héroes de la novela romántica son a menudo hombres que desafían la sociedad. No son representaciones realistas, sino figuras grandiosas, magníficas, exageradamente buenas o malas. Los protagonistas románticos se rebelan contra las trabas que cohíben su espíritu, tienen ansias de libertad y muchas veces encontramos en ellos semejanzas con los personajes de la Edad Media caballeresca. Muchos de estos personajes son protagonistas ficticios llenos de angustias metafísicas y preocupaciones filosóficas, que sienten la vida como un problema insoluble y se creen víctimas de un ciego destino que determina la existencia humana. Los novelistas románticos idealizan al hombre 
solitario o marginado que lucha contra fuerzas hostiles: el indio, el negro, el esclavo, el patriota, ciudadanos comunes que no tienen historia conocida y que al novelista romántico le gusta crear. La finalidad de gran parte de los autores de estas novelas fue contribuir a la creación de una conciencia nacional familiarizando a sus lectores con los personajes y los sucesos del pasado.

Una novela representativa de esta etapa es Guatimozín (1846) de Gertrudis Gómez de Avellaneda. Si en la poesía de Avellaneda el "yo" es el centro de atención de la poeta, en su narrativa, como es el caso de la novela Guatimozín, el individualismo romántico se manifiesta de manera diferente. No es tanto lo íntimo y lo personal de la autora lo que se proyecta al lector, sino una nota individual en el estilo que influye poderosamente en el lenguaje literario, dando lugar a una expresión que intenta ser reflejo directo de la personalidad de la novelista. A los lectores contemporáneos, nos sorprende al aproximarnos a esta obra, la cantidad de notas al pie de las páginas, pero no debería extrañarnos, dada la psicología de la época romántica, la aparición de un estilo que busca lo original, lo nuevo, lo sorprendente, medios con que Avellaneda como otros, trataban de afirmar su "yo" frente a la tradición neoclásica. Desaparece en la novela Guatimozín, el sentido de la perfección que encontramos en la poesía de Avellaneda, que aunque romántica, está 
permeada de la perfección de la estética neoclásica en que fue educada la escritora cubana.

El acentuado individualismo del hombre romántico se rebela contra las trabas que hasta entonces cohibían su espíritu, y, en efecto un ansia de libertad se refleja en todas las manifestaciones de la época. En Guatimozín, Avellaneda plasma las ansias de libertad del pueblo azteca, ante la usurpación española. Creen como todo romántico que no son la razón, ni la religión las que determinan las conductas, sino la naturaleza libre y el impulso espontáneo. De ahí la simpatía que inspira la figura del salvaje. Simpatía que se hace notoria en Guatimozín, en el tono altisonante, fascinante, defensivo y a veces justificante con que Avellaneda nos presenta al protagonista de la novela.

El sentimentalismo y la imaginación se imponen a la fuerza de la razón proclamada por los neoclásicos. Avellaneda da rienda suelta a su imaginación al describir la capital de los aztecas, al reproducir conversaciones de personajes históricos como Montezuma y Cortés, así como en la descripción de la campiña mexicana. A pesar de que la autora intenta presentarnos realidades de la conquista de México, su imaginación romántica nos aleja de la precisión histórica. Avellaneda se deja llevar por su imaginación, por sus sentimientos, por su personal instinto. Y es que el romanticismo es una invitación al viaje y cuando esto no es posible, la imaginación se encarga de forjar mundos de poesía y 
ensueños, que se instalan en la Edad Media caballeresca o en lugares exóticos, llenos de misterio como el imperio azteca.

Los románticos padecen de angustia metafísica y grandes preocupaciones filosóficas. Ellos sienten la vida como un problema insoluble. Su instinto les denuncia la existencia de fuerzas naturales que escapan a todo conocimiento racional, y esta angustia la encontramos, a lo largo de la novela, en los personajes de Montezuma, y Cortés, quienes se creen victimas de un destino que determina la existencia humana.

En esa vuelta a la Edad Media de los escritores románticos y en esa búsqueda de motivos exóticos, el romanticismo rescata monumentos literarios olvidados, como es el caso de los romances. Avellaneda, en la segunda parte de esta novela pone en boca del Astrólogo Botello, un romance morisco, la autora de Guatimozín también contribuyó como otros escritores románticos de habla castellana a que volvieran a salir a escena los héroes de la vieja poesía épica y del romancero.

Gertrudis Gómez de Avellaneda en su novela Guatimozín se aparta del neoclasicismo, exalta el amor, el patriotismo, la libertad e idealiza al rebelde. Como romántica, cultiva el tono altisonante, gusta de lo ostentoso, lo grandioso, lo magnífico. Vuelve al pasado, explora tradiciones y leyendas. Más que la exactitud histórica, le interesa lo fantástico, misterioso y exótico del mundo azteca, donde la imagen del hombre solitario, como Cortés, lucha contra fuerzas hostiles y donde otro 
hombre, Montezuma, es sacrificado por las fuerzas fatídicas e irreversibles del destino.

Otras novelas históricas se producen en Hispanoamérica durante la segunda mitad del siglo XIX, como por ejemplo, El filisbustero (1851) de Justo Sierra, El Inquisidor Mayor (1852) de Manuel Bilbao y La novia del hereje (1854) de Vicente Fidel López. Enriquillo (1882) de Manuel de Jesús Galván, basada en los escritos de Fray Bartolomé de las Casas, tiene como centro la corte de Diego Colón y el cacicazgo de Guaracuya o Enriquillo y su alzamiento. Casi todos sus personajes principales son históricos, narra la historia de manera tradicional, o sea sin alejarse del discurso historiográfico tradicional.

Al finalizar el siglo XIX, las ideas del positivismo favorecen a la novela realista y naturalista. Dentro de este nuevo contexto del pensamiento hispanoamericano se enfatiza la objetividad y la documentación. En esta época se produce la novela histórica Durante la reconquista (1897) de Alberto Blest Gana que documenta el período posterior a las primeras batallas por la independencia de Chile en que los españoles intentan la recuperación del poder en la región.

A comienzos del siglo XX la novela histórica evoluciona hacia el modernismo, aunque de manera tangencial, pues fue en la poesía donde el movimiento modernista tuvo su mayor fuerza. La gloria de don Ramiro (1908), de Enrique Larreta, es quizás la muestra más representativa de la 
novela histórica modernista. Como en los textos de los primeros modernistas, en esta novela ya encontramos la presencia de una nueva estética, nuevas maneras expresivas en las que se percibe el influjo del Simbolismo, Parnasianismo e Impresionismo. La riqueza de modalidades coincidentes en la novela de Larreta nos lleva a ver La gloria de don Ramiro como un texto ecléctico por excelencia.

Es difícil definir la novela modernista, como es difícil definir qué es el Modernismo. Pero es un error reducir el concepto de novela modernista, y Modernismo, al esquema estrecho de creación escapista con un interés único en lo puramente estético, ajeno a las preocupaciones sociales sin repercusión en la literatura actual, aunque así lo vea la crítica tradicional. Todavía hoy, a pesar de que se han realizado algunos estudios sobre la novela modernista, hay una visión muy limitada sobre el tema que exige lecturas más actuales que desmonten las concepciones estereotipadas y canónicas.

Encontramos en las novelas modernistas un interés que va más allá del lenguaje poético metafórico y la preocupación esteticista. Una lectura actual de las novelas modernistas nos permite encontrar un interés por la introspección, la cual se convierte en indagación, no sólo personal sino de la historia, a través de una alternancia entre el mundo interior y exterior, entre ficción y realidad histórica. Algunas novelas como La gloria de don Ramiro miran al pasado y utilizan de éste ideas que 
podrían aplicarse al presente. El pasado no constituye solamente una recreación histórica, sino una retextualización porque el arte modernista es un arte renegociado.

La novela modernista hispanoamericana intenta constituir, al nivel de la ficción textual, un mundo que sea representativo de la realidad contemporánea, o también como es el caso de la novela de Larreta, una realidad histórica y geográficamente alejada, pero siempre relacionada con la realidad del momento. Al respecto plantea Klaus Meyer-Mineman:

En esta novela de Larreta, la realidad novelística, de acuerdo con la conciencia renovada de la hispanidad de América (conciencia despertada por la guerra de 1898 y la experiencia de creciente imperialismo norteamericano) quiere evocar la raíz común de todos los países hispanoamericanos. Es ésta la razón por la cual, al final de la obra, se le revela su verdadera gloria al protagonista en el encuentro con la santa de Lima. Por otra parte, esta misma realidad novelística, el tiempo de Felipe II, funciona como medio hostil para un protagonista que nunca llega a la plena conciencia de ello. (252)

Cuando Larreta nos pinta Ávila nos está pintando la España sombría de Felipe II donde la gente vive vidas asfixiadas por las ideas sociales, la política del Estado y por los miedos de la religión. La visión de España en la novela de Larreta refleja una actitud crítica de los elementos sociales, 
políticos y culturales que conforman su realidad inmediata. En esta visión Larreta define su imaginario social y cultural expresando un discurso de rebeldía, una proyección colectiva de la necesidad de reflexión y búsqueda de nuevos destinos históricos. Enrique Larreta se convierte en arqueólogo recreador de la España del Siglo de Oro. Larreta vuelve a desenterrar nuestros orígenes ibéricos a través de un argumento que comienza en España y termina en América, pero que se une nuevamente a España a través de la esencia de Santa Rosa de Lima y Santa Teresa de Jesús.

Es necesario tener en cuenta que la novela modernista se propone definir cuál es el papel del intelectual en el mundo moderno. Coincide, por tanto, el nacimiento del movimiento modernista con la búsqueda por parte del intelectual hispanoamericano de su identidad propia. Es necesario que tengamos esto en cuenta al repensar el Modernismo a través de La gloria de don Ramiro. La religión funcionará desde una perspectiva moralizante y estética y no teológica para aludir a la conversión espiritual y cultural que los modernistas buscaban a principios de siglo. Observamos en La gloria de don Ramiro los resultados de esta indagación acerca de los orígenes de la cultura hispánica e hispanoamericana. Esta indagación o la búsqueda de don Ramiro es parte de la nueva vitalidad del discurso literario en Hispanoamérica. Contribuyen también a hacer de La gloria de don Ramiro 
un texto moderno y ecléctico el manejo de la ironía, la victimización de personajes, la intertextualidad y la complicidad del lector; características que se convierten en contribuciones de la novela modernista a la novela actual.

Otro aporte de La gloria de don Ramiro a la novela moderna es la literaturización de personajes. Encontramos personajes como don Ramiro que son un poco Quijote, Don Juan y Lazarillo. También encontramos personajes que son un poco Celestina y otros, como Beatriz, que tienen cierta similitud con los personajes de las novelas de caballerías. En La gloria de don Ramiro los personajes son conscientes de que están actuando, como ocurre en Don Quijote, donde los personajes se saben leídos; se comportan teatralmente; parecen estampas que se mueven. Los personajes tienen un tipo de autoconciencia que les permite no sólo percibirse a sí mismos como protagonista de una obra, sino también examinar y reaccionar ante la realidad del contexto literario.

La gloria de don Ramiro es una novela histórica que combina diferentes procedimientos románticos, parnasianos e impresionistas. En esta novela se alterna el lenguaje metafórico, la arqueología, la preocupación estética con la humana y se mira hacia el pasado no como recreación histórica sino como retextualización, utilizando de otras épocas ideas y realidades que podían aplicarse al presente. 
A comienzo del siglo XX se producen otras novelas históricas dentro de la estética modernista, tales como El mar dulce: crónica novelesca del descubrimiento del Río de la plata (1928) de Roberto Payró, donde se relatan los preparativos de Juan Díaz de Solís y su viaje al sur de América. También El evangelio del amor (1922) de Enrique Gómez Carrillo, cuya trama tiene lugar durante la época del imperio bizantino del siglo XVI. Otras novelas importantes de principio de siglo son Lanza y Sable (1914) del uruguayo Eduardo Acevedo Díaz y La marquesa de Yolombo (1928) del colombiano Tomás Carrasquilla.

Durante las primeras décadas del siglo XX en Hispanoamérica algunas novelas históricas responden a la necesidad de sedimentar la identidad nacional, y en algunas de estas novelas se enfatiza el racismo y la explotación económica. Se destacan, por ejemplo, Matalaché (1924) de Enrique López Albújar; Las lanzas coloradas (1931) de Arturo Uslar Pietri, que tiene lugar durante la guerra de independencia; Pobre Negro (1937) de Rómulo Gallegos, situada en la época esclavista y de la guerra federal; El camino de El dorado (1947), de Uslar Pietri, se refiere a la llegada de los españoles y narra la fracasada búsqueda de esta región mítica por Lope de Aguirre. ${ }^{3}$

Los primeros autores de novelas históricas en Hispanoamérica buscaban en el pasado las raíces que ayudaran a definir y crear el espíritu nacional. Durante el criollismo esta búsqueda se centró en lo telúrico. 
Hasta este momento la novela histórica se atenía a lo relatado por el discurso oficial de la historia y se proponía una recreación fiel del marco histórico local o nacional. Se intentaba lograr una reproducción de la realidad sociohistórica en la que no se cuestionaba en momento alguno "las verdades" de la historia oficial. La novela histórica tradicional que floreció en el siglo XIX construyó mundos cerrados, donde los hechos pasados parecían narrarse a sí mismos.

Seymor Menton es quien propone que con la publicación en 1949 de la novela El reino de este mundo de Alejo Carpentier se inicia la nueva novela histórica, la cual tendrá su apogeo tres décadas después. Menton destaca seis rasgos que caracterizan a la nueva novela histórica, aunque no es necesaria, según él, la totalidad de ellos para que una obra sea considerada como "nueva" novela histórica. Los seis rasgos son: 1) lo bajtiniano, es decir, lo dialógico, lo heteroglósico y lo carnavalesco; 2) la intertextualidad; 3) la metaficción o los comentarios del narrador sobre la creación de su propio texto; 4) la presencia de un protagonista histórico; 5) la distorsión consciente de la historia por omisiones, exageraciones y anacronismos; y 6) la subordinación de la reproducción mimética de cierto periodo histórico a conceptos filosóficos trascendentes.

Fernando Aínsa es otro de los autores que han postulado rasgos definitorios de la nueva novela histórica. Según Fernando Aínsa éstos son: 
1. Relectura de la historia fundada en un historicismo crítico.

2. Impugnación de las versiones oficiales de la historia.

3. Multiplicidad de perspectivas (múltiples verdades históricas).

4. Abolición de la distancia épica ("presentización" y desmitificación de la historia).

5. Distanciamiento de la historia oficial mediante su reescritura paródica.

6. Superposición de tiempos históricos diferentes.

7. Historicidad textual o pura invención mimética de crónicas y relaciones.

8. Modalidades expresivas:

- Falsas crónicas disfrazadas de historicismo.

- Glosa de textos auténticos en contextos hiperbólicos o grotescos.

9. Relectura distanciada, "pesadillesca" o acrónica de la historia mediante una escritura carnavalesca.

10. Preocupación por el lenguaje: arcaísmos, pastiches, parodias, y sentido del humor agudizado.

Los rasgos definitorios de la nueva novela histórica o nuevo historicismo que han postulado críticos como Menton y Aínsa no son ajenos a la historiografía postmodernista de Keith Jenkins, ni a la filosofía de la historia de Hayden White, o al modo narrativo conocido como 
"metaficción historiográfica" (término con el que Linda Hutcheon se refiere a la paradójica combinación de autorreflexión y meditación historiográfica tan extendida dentro de la ficción posmodernista).

Resumiendo los postulados de Menton y Aínsa diremos que la nueva novela histórica se caracteriza por la distorsión consciente de la historia mediante exageraciones y anacronismos, la desmitificación del registro histórico y la visión carnavalesca de la historia. El humor, la ironía, la irreverencia, la transgresión y lo paródico son elementos del discurso carnavalesco de la nueva novela histórica que permiten la problematización del discurso oficial de la historia, de la cultura y de lo socialmente aceptado. En esta nueva narrativa hay un mayor énfasis en los seres marginados, periféricos y alejados del discurso oficial. Estas novelas ofrecen una relectura de las versiones oficiales de la historia a través de la multiplicidad de perspectivas o múltiples verdades históricas. Para distanciarse de la historiografía oficial los autores de la nueva novela histórica recurren a la reescritura paródica y a la superposición de tiempos históricos diferentes. Usan diferentes modalidades expresivas como las falsas crónicas disfrazadas de historicismo y la glosa de textos auténticos en contextos hiperbólicos o grotescos. La nueva novela histórica permite al lector un relectura distanciada o acrónica de la historia mediante la escritura carnavalesca. 
Entre las nuevas novelas históricas, escritas a finales de los años sesenta, destaca El mundo alucinante (1969) de Reinaldo Arenas. Esta novela es la primera novela histórica en apartarse de manera radical del discurso historiográfico tradicional. ${ }^{4}$ Por primera vez una novela histórica rescata a un personaje olvidado por la historia oficial mediante un estilo carnavalesco caracterizado por la irreverencia, la hipérbole y la ironía.

La intertextualidad, otro de los rasgos de la nueva novela histórica, está muy presente en El mundo alucinante. En esta novela se palpa desde el principio hasta el final no sólo las citas textuales de la vida real del personaje sino la ideología del mismo expresada por Arenas en un lenguaje fantástico que nos ayuda a transgredir las secuencias espaciotemporales de la realidad y entrar en un mundo literario lleno de imágenes oníricas. La obra comienza con una carta que Arenas escribe a Fray Servando. En la carta el autor le dice al fraile que desde que lo descubrió en las páginas de un texto de historia mexicana, lo ha seguido a través de bibliotecas infernales. En la carta le asegura que ambos, él y el fraile, son una misma persona. Esta confesión del autor ratifica el proceso simbiótico que ocurre entre el narrador y el personaje; y por otro lado, explica el carácter intertextual de la obra ya que ésta se nutre no sólo de las Memorias y la Apología de Fray Servando sino también, según admite el autor, de discursos y cartas del fraile, al igual que de otros documentos históricos. 
Como parte de este juego intertextual, Arenas recurre a obras de la literatura universal tales como el Orlando de Virginia Wolf, Don Quijote de Miguel de Cervantes y la Divina Comedia de Dante. La inclusión de Orlando es aparentemente una alusión al controversial personaje de Virginia Wolf, que como personaje ficticio, no sólo transgrede las leyes de la historiografía rompiendo las normas espacio temporales de igual forma que Fray Servando y sus múltiples voces, sino que como personaje social se rebela también contra el orden establecido. Algunos capítulos en El mundo alucinante nos hacen recordar los capítulos del Quijote, los cuales en su mayoría empiezan con la frase: "De lo que........" También hay un capítulo en esta novela de Arenas que nos remite a la Divina Comedia, en donde Dante, se adentra en la Selva Oscura como lo hace Fray Servando en los jardines reales en su intento de entrevistarse con el rey español Carlos IV.

La estructura dialógica o dialogismo es uno de los conceptos bajtinianos más destacados en la novela de Arenas. Los fenómenos de desdoblamiento, convergencia o diferencias entre las voces del autor, narradores y personajes presentes en un relato confieren ese carácter polifónico y dialógico al texto literario que constituye una opinión pluridiscursiva sobre el mundo. Ese carácter dialógico y polifónico lo hallamos en El mundo alucinante donde los capítulos se presentan por triplicado siendo cada uno de ellos narrados en diferentes personas: "Yo", 
"Tú" y "El". Este recurso del autor le permite aportar tres visiones complementarias de la personalidad del fraile. El "Yo" puede entenderse como el narrador protagonista, o lo que Roland Barthes ${ }^{5}$ Ilamaría narrador homodiegético por referirnos la historia dentro de la historia en la que participa, el "Tú" actúa como subconsciente y el "El" como narrador básico o narrador heterodiegético, que nos revela la historia sin participar en ella. Las voces rehacen la historia creando un mundo alucinante donde la realidad se distorsiona, pero nos permite ver su función en la novela, que es reafirmar las convicciones ideológicas de Fray Servando. Como señala Perla Rozencvaig en Reinaldo Arenas: Narrativa de Transgrsesión:

A pesar de la ambigüedad que produce la constante contradicción de los hechos que se cuentan, la trilogía de voces ofrece una visión compacta del fraile que escapa a toda confusión premeditada y encaprichada en tornar borrosa la imagen del cura. (18)

En esta novela la parodia y la sátira son utilizadas para transgredir, con una fuerte ironía, el discurso de la historiografía canónica. En El mundo alucinante se recoge lo más crudo del humor areniano en su vertiente más grotesca.

La combinación de conceptos como el dialogismo inherente al lenguaje, la polifonía, recurso a través del cual los diferentes personajes pueden expresarse en distintas voces sin tener que subordinarse a la del 
autor, la inversión de las jerarquías y la transgresión de la autoridad, nos Ileva a lo que Bajtín Ilama carnaval. ${ }^{6}$ El mundo alucinante nos transporta a un mundo de aventuras y nos ofrece una visión carnavalesca de la historia donde la distorsión del discurso oficial y las inversiones jerárquicas ocurren con naturalidad. Se crea una nueva realidad que, aunque algo anacrónica, sirve para cubrir los vacíos de la historia oficial. En El mundo alucinante se observa la carnavalización en diferentes planos: en el narrativo, en el uso de diversos géneros literarios, en la dialogización de la intertextualidad y en sus tendencias alegóricas. La carnavalización en el plano narrativo ocurre desde el principio cuando van apareciendo los diferentes narradores. Otro de los rasgos carnavalescos en esta novela es la combinación de la prosa, el verso rimado y las rimas paródicas intercaladas con juegos de palabras.

Arenas muestra en El mundo alucinante una fuerte influencia rabelasiana en su predilección por el uso de la hipérbole. Dos de los capítulos que mejor ejemplifican esta tendencia son el veinticuatro y el cinco. En el veinticuatro se explica el intricado sistema carcelario de la España imperial. Las cadenas se subdividen para apresar cada diente individualmente y a cada cabello y pestaña; el peso de las cadenas es tan grande que provoca el hundimiento del fraile. En el capítulo cinco, el más paródico, introduce en la novela al personaje de Borunda, un ser de 
forma de pipa que aunque humano posee dimensiones físicas descomunales.

El mundo alucinante recurre a la superposición de tiempos

históricos diferentes. El autor mezcla contextos históricos y culturales de épocas que van desde la Revolución Francesa hasta las luchas independentistas en Hispanoamérica, incluyendo detalles de la Revolución Cubana de 1959. Las distorsiones del tiempo impregnan la obra de Arenas en su totalidad; el tiempo no sólo se subvierte desde un punto de vista histórico, sino también como transcurso lineal, irreversible, por ejemplo: la madre de Servando está unas veces viva y otras muerta, las hermanas han realizado acciones sin haber nacido, y muchos de los hechos a través de la novela se deshacen o se niegan como ocurre con el título del Capítulo 16: "De mi llegada y no llegada a Pamplona. De lo que allí me sucedió sin haberme sucedido"

La novela histórica en Hispanoamérica desde sus inicios hasta nuestros tiempos ha ido evolucionando y transformándose. Este tipo de novela, como hemos expresado, tuvo sus primeras manifestaciones en el siglo XIX dentro del marco del romanticismo y el realismo. A comienzos del siglo XX la novela histórica evoluciona hacia el modernismo, aunque de manera tangencial. En el inicio de la segunda mitad del siglo XX la novela histórica empieza a transformarse, con la publicación de la novela El reino de este mundo para convertirse en lo que ha venido en llamarse 
"la nueva novela histórica", cuyos rasgos han sido postulados por Seymour Menton y Fernando Aínsa, respectivamente. Pero es a partir de la novela El mundo alucinante que la novela histórica hispanoamericana se aparta de manera radical del discurso historiográfico tradicional acercándose a la historiografía postmodernista y al modo narrativo conocido como "metaficción historiográfica".7

\section{LA NUEVA NOVELA HISTORICA Y EL PENSAMIENTO POSTMODERNISTA}

La nueva novela histórica a partir del Mundo alucinante empieza a alejarse de manera más radical del discurso historiográfico tradicional aproximándose a lo que Linda Hutcheon ha llamado metaficción historiográfica, grupo al que pertenecerán novelas como Terra Nostra (1975) de Carlos Fuentes, Daimón (1978) de Abel Posse, El arpa y la sombra (1979) de Alejo Carpentier, Crónica del descubrimiento (1980) de Alejandro Paternain, La guerra del fin del mundo (1981) de Mario Vargas Llosa, Los perros del paraíso (1982) de Abel Posse, Gringo Viejo (1985) de Carlos Fuentes, La loma del Ángel (1987) de Reinaldo Arenas, La campaña (1990) de Carlos Fuentes, El largo atardecer del caminante (1992) de Abel Posse y Vigilia del Almirante (1992) de Augusto Roa Bastos, entre otras.

La metaficción historiográfica es una variedad particular dentro de la metaficción postmodernista. ${ }^{8}$ Las obras que se adscriben a este modo 
narrativo son obras que reflexionan sobre sí mismas y sobre el proceso de producción y recepción del texto literario. Estas obras dan la falsa impresión de que disfrutan de autonomía fictiva y lingüística, impresión que el propio texto deshace. Los personajes y acontecimientos históricos dentro del contexto fictivo del texto literario cuestionan las pretensiones de objetividad y empirismo del discurso histórico oficial. Aunque estas obras se caracterizan por ser autorreferenciales y reflexivas no dejan de estar sujetas a la historia y a su vez la historia ha sido incapaz de escapar a las limitaciones que tiene toda construcción cultural. La aparición de esta nueva narrativa se ha producido, según Linda Hutcheon, simultáneamente a la consolidación de la nueva filosofía de la historia de autores como Hayden White o Dominick LaCapra.

Linda Hutcheon, uno de los críticos que con más profundidad ha analizado la relación existente entre las nuevas tendencias de la narrativa y el postmodernismo en general, considera la metaficción como otra manifestación del postmodernismo. Hutcheon ve en la ficción postmodernista un código doble que permite expresarse satisfaciendo tanto a los códigos modernos como aquéllos de carácter popular. De acuerdo con Hutcheon, la ficción postmodernista permite la participación activa del lector, el cual adquiere una identidad compuesta con el escritor y el crítico. Esta narrativa también tiende a jugar con las posibilidades del significado y de la forma, lo que demuestra su carácter experimental. 
Toda aproximación a la historia, toda teorización, análisis crítico, incluso el acto de escribir en sí tiene, de acuerdo con Hutcheon, una implicación ideológica:

Thanks to the pioneering work of Marxists, feminists, gays, blacks and ethics theorists, there is a new awareness in these fields that history cannot be written without ideological and institutional analysis, including analysis of the act of writing itself. It is no longer enough to be suspicious or playful as a writer about art or literature (or history, though there it never really was); the theorists and the critic are inevitably implicated in both ideologies and institutions. (A poetics of postmodernism 91)

Lo planteado niega la llamada "objetividad" tanto del discurso histórico tradicional como de la crítica literaria, cuyas interpretaciones se esconden detrás de la tercera persona.

El concepto de modernismo es para muchos un concepto angloamericano. ${ }^{9}$ Otros, como Linda Hutcheon, platean que no debe limitarse la poética del modernismo a esta cultura específica. Hay críticos como Wilde, Brooke-Rose y Lodge que ven el noveau roman como parte de la escritura postmodernista y casi toda la crítica incluye lo que Severo Sarduy ha llamado "neo - barroco" en la cultura hispana como un, 
equivalente a postmodernismo, dado que "modernismo" tiene en el contexto hispanoamericano y español un significado diferente.

Nietzsche y Heidegger, son en buena medida, los pensadores que más han influido en la teoría de la postmodernidad. Tal vez, el aspecto más desafiante del pensamiento de Nietzsche es su rechazo de cualquier tipo de fundamentación. La tantas veces citada frase que anuncia la muerte de Dios proclamada por Nietzsche no sería sino el certificado de defunción de las "supremas verdades" que la humanidad había mantenido como base de la existencia teórica y práctica y "El sacerdote sabe, tan bien como cualquiera, que ya no hay Dios, ni pecado, ni Salvador, que el libre albedrío y el orden moral son mentiras" (Nietzche, Obras Completas 446). Se trata de la muerte de los grandes relatos sustituidos por una ciencia que se autolegitima en su efectividad. Se trata del imperio del signo que se basta a sí mismo y nos abastece a todos para que las cosas sigan funcionando sin cambios reales. Se trata de la constatación de que la razón se convierte en instrumentalidad. Se trata, en fin, de la visión de un mundo desnudo, despojado de soportes, arruinado por lo científico técnico, desprendido de la religión que desafía a los hombres pidiéndoles que vivan como mortales, sin otro mundo que éste, sin otro suelo que sus pies y sin otra moral que la vida por la vida. El mundo se sustenta en nuestros hombros de esta manera, y no al revés. Nietzsche, de esta manera, rompe con el optimismo de la modernidad. 
Heidegger es el otro punto de referencia a la hora de hablar de la postmodernidad. La postmodernidad que se apoya en Heidegger es exigente. Así, distingue entre un pensamiento en verdad evocativo y cualquier otro tipo de pensamiento que, por radical que se presente, permanece en la vieja escuela de la dialéctica. En Heidegger no es la historia lo que importa sino la tradición y el destino. Por eso lo que compete al ser humano es recordar y ser guardián o testigo del ser; un ser que es acontecimiento y, en cuanto tal, se escapa. Sólo podemos rastrear sus huellas. Es así como la caducidad se hace también presente y todo se torna movedizo, no asentado. Nietzsche y Heidegger son dos figuras que componen el trasfondo de la reacción postmoderna.

De la postmodernidad se podría decir que desconfía de las estructuras fijas y de las verdades fundamentales. Para el pensamiento postmoderno no existe una razón que oriente y resuelva. Es precisamente este relativismo el que hace difícil definir al postmodernismo. Como señala Keith Jenkins:

Postmodernist is a difficult area. Because post-modernists see nothing as fixed or solid, this jeopardizes the sorts of attempts that they may to define what they see themselves as part of, whilst some commentators, have doubted [...] the very existence of the condition. (Re-Thinking History 59) 
El postmodernismo es contradictorio y a veces va acompañado de cierta retórica negativa que recurre a vocablos como discontinuidad, disrupción dislocación, indeterminación y antitotalización. ${ }^{10}$

Un rastreo del uso del termino "postmodernismo" nos revela que los primeros en usar el término fueron Federico de Onís en 1934, Dudley Fitt usó el termino "post - Modern" en 1942 y Arnold Toynbee "Post Modern" en 1947. Pero es a partir de los últimos años de la década del cincuenta y los primeros del sesenta cuando el discurso crítico y el debate de lo que se ha llamado postmodernismo tomó fuerza de manera creciente con críticos como Irving Howe (1959), Leslie Fiedler y Susan Sontag, a mediado de los sesenta, Ihab Hassan en 1969 y posteriormente, David Antin (1971), William Spanos (1972) y Charles Altieri (1973). A partir de los años setenta con figuras como Klinkowingz (1975), Lyotard (1979) y Mellard (1980), se intensifica el debate e intento de definición de la postmodernidad.

La postmodernidad se entiende generalmente como el estado que corresponde a las sociedades postindustriales. La postmodernidad, de esta manera se contrapone a la modernidad. A efectos de comprensión podemos señalar tres momentos de modernidad en relación a la problemática de la historia:

Ilamamos modernidad al momento emergente de ésta desde el Renacimiento hasta Descartes; segunda modernidad, a la 
conciencia propiamente constitutiva desde Descartes hasta

Kant; y tercera modernidad, a la autoconciencia moderna, del idealismo alemán hasta Hegel. (Sevilla 65)

Etimológicamente "moderno" procede del latín modernus, que significa "lo de hace poco" y se usó por primera vez para oponer el cristianismo naciente al paganismo derrotado.

Durante el siglo XVII se repetirá la misma querella de "los antiguos y los modernos", lo nuevo se opone a lo viejo. Durante la llustración y el Romanticismo se mirará a la antigüedad de manera distinta: los Ilustrados para resaltar su modernidad; los románticos para evocar un tiempo clásico mejor. El modernismo de final de siglo XX radicalizará la idea de novedad hasta considerar caduco todo lo que no esté a la altura de un estilo de vanguardia. La relación entre lo "moderno" y lo "clásico" ha perdido su referencia histórica fija.

El concepto de postmodernidad, a pesar de haber sido analizado exhaustivamente, no ha conseguido disipar el halo de confusión que lo rodea y que sugiere que la postmodernidad es un movimiento difuso, mitad protesta, mitad resignación, semisubversivo o complaciente, extremo o incoherente." La postmodernidad es vista como rechazo a lo moderno: 
Desvela y ataca las pretensiones de fundamentación última, trascendental, propias de buena parte de la humanidad.

Ridiculiza la ceguera estética ilustrada. Recela no menos del olvido de la autonomía individual; secuestradas por una racionalidad esencialmente universal. $Y$ trata de recuperar, en suma, los elementos emotivos, retóricos y marginales que habían sido reducidos a mera accidentalidad. (Sádaba 195) La oposición a la modernidad se manifiesta a través de diferentes expresiones como son las literarias, artísticas, arquitectónicas, entre otras.

Los detractores del postmodernismo plantean que el postmodernismo es antihistórico. Tanto el marxismo ortodoxo como los críticos tradicionalistas atacan no sólo la narrativa contemporánea sino también una gran parte de la teoría postestructuralista (desde la semiótica hasta la desconstrucción. Por otro lado, los defensores del postmodernismo plantean que la aproximación postmodernista a la historia y a la literatura nos enseña que tanto la historia como la narrativa son discursos y que ambos constituyen sistemas de significación a través de los cuales le damos sentido al pasado.

No podemos ver el fenómeno postmodernista como un movimiento unitario, ni como una tendencia ideológica cuya esencia pertenece a la izquierda, al centro, o la derecha. Según los estudios de Linda Hutcheon, 
los años 60 constituyen el momento de formación ideológica de muchos de los pensadores y artistas postmodernos. La experiencia social, política e intelectual de los años 60 ayudó a que el postmodernismo fuera visto como lo que Julia Kristeva Ilama "writing-as-experience-of-limits" (136 41) en referencia a las limitaciones, entre otras, del lenguaje, la subjetividad, y la identidad sexual. Todas estas limitaciones de la escritura han contribuido a la "crisis de legitimidad" que vieron filósofos como Jean François Lyotard y Jurgen Habermas como parte de la condición postmoderna.

En su obra La condición postmoderna Lyotard caracteriza al postmodernismo como la muerte de todos los centros y la incredulidad hacia todas la metanarrativas. ${ }^{12}$ Los centros han dejado de ser legítimos, como por ejemplo, lo euro, lo anglo, el logos, el género, así como las estructuras universales. Nos encontramos ante un fenómeno de fragmentación universal, de incredulidad hacia todas las metanarrativas, hacia aquellas grandes estructuras que le dieron sentido y vitalidad al mundo occidental. De acuerdo con las ideas de Lyotard, el estatuto del saber cambia en el momento en que las sociedades entran en la edad posindustrial, correspondiéndoles una cultura postmoderna. La narratividad pierde sus grandes temas: el gran héroe, los grandes periplos, los grandes peligros y el gran propósito y se"dispersa en nubes de elementos lingüísticos narrativos" (Lyotard 10). Asistimos, de acuerdo 
con el autor, a la crisis de las "grandes narraciones" legitimadoras de la modernidad. Los meta -relatos se fundaban en un proyecto o idea a realizar y su legitimación venía dada por la expectativa de su cumplimiento.

Ya en el siglo XIX con el anuncio de la muerte de Dios se empezaba a desarticular una de las grandes metanarrativas universales: la metanarrativa teológica. Durante el siglo XIX la literatura y la historia fueron consideradas como ramas del mismo árbol del aprendizaje que tenían el propósito de guiar y elevar el conocimiento del hombre. Ambas eran el producto de la mente humana. Los escritores de historia y literatura en el siglo XIX ofrecían una continua e integrada experiencia narrativa que tuviera relevancia y significado para la condición humana.

El divorcio entre la historia y la literatura vino con el auge de la "historia científica" durante las últimas décadas del siglo XIX. La diferencia entre historia "literaria" y "científica" se acrecentó entre los seguidores de Hegel y de Ranke:

between those who believe that the writing of history began with a theory that made order out of the course of events; and those who believed it began with a gathering of information about events from which certain justifiable generalizations about them might emerge (Nye 126). 
A partir de ese momento la historia empezó a ser considerada como una ciencia y los historiadores acordaron que las "historias literarias" escritas a principio del siglo XIX eran inaceptables bajo los nuevos estándares de "la modernidad". Varias décadas después, en las últimas décadas del siglo XX, todo el historicismo empírico y objetivista empezaría a ser refutado, y "las verdades" a ser cuestionadas por una nueva aproximación a la historia: la aproximación postmodernista.

En el mundo postmoderno la verdad aparece como algo cada vez más irreal. Los historiadores y el pensamiento actual han sido impactados por el relativismo y el escepticismo. En la postmodernidad no existen verdades históricas. Las verdades son cuestionadas, porque son vistas como construcciones sociales determinadas por la ideología dominante. Si es cierto que nuestra cultura tuvo una larga tradición donde la verdad era algo que se encontraba y no se creaba, hoy en día esta percepción de la verdad ha cambiado.

En los tiempos postmodernos "la verdad" y la "historia oficial" son consideradas partes del discurso del poder. Al respecto, en Power/Knowledge, Michel Foucault señala:

true isn't outside power, or lacking in power..... Truth is a thing of this world: it is produced only by virtue of multiple forms of constraint. And it induces regular effects of power. Each society has its regime of truth, its 'general politics' of 
truth: that is, the types of discourse which it accepts and makes function as true.... (131)

De acuerdo con lo planteado, "las verdades" están sujetas a interpretaciones que pueden ser vistas como "ficciones útiles" del poder para ejercer el control.

Foucault, cuya obra ofrece una crítica que fustiga los conceptos básicos del realismo histórico, propone como alternativa a la historia tradicional el análisis genealógico, el cual busca deslegitimizar el presente cuestionando las causas del pasado. ${ }^{13}$ Los conceptos de los historiadores empíricos como continuidad y progreso no tienen lugar dentro del pensamiento de Foucault. Su filosofía de la historia es un intento de desenmascarar a los historiadores empíricos que desde finales del siglo XIX fueron presentados como los buscadores de la verdad. La investigación histórica, de acuerdo con Foucault, no nos conduce a la verdad, sino al conocimiento, entendido como fuente del poder. La escritura de la historia se convierte entonces en el conocimiento que se tenga sobre ese pasado y tendrá el efecto de legitimar cierta versión del presente.

Otra aproximación a la historia también caracterizada por el escepticismo de la postmodernidad es la ofrecida por Hayden White. White parte de la relativización del conocimiento histórico planteado por pensadores europeos como Válery, Heidegger, Sartre y Lévi-Strauss y de 
la refutación de la naturaleza científica de la historia de los filósofos angloamericanos como Mink, Dray y Danto. Su análisis, como señala Juan-Navarro es "una aproximación tropológica al discurso histórico" (Archival 51). En el libro Metahistory, Hayden White propone un análisis formal de la estructura del discurso historiográfico. White señala, como resultado de sus estudios e investigaciones, siete conclusiones.

1. No puede haber una historia, propiamente dicha, que no sea a la vez una filosofía de la historia.

2. Los posibles modos de la historiografía son al mismo tiempo los posibles "modos" de la filosofía especulativa de la historia.

3. Esos "modos" son en realidad formas de una poética que analíticamente les precede y eso determina las teorías particulares usadas para dar a sucesos históricos el aspecto de una explicación.

4. No existe una base teórica válida en la cual uno pueda con legitimidad reconocer que un "modo" sea más realista que otro.

5. Estamos obligados a escoger entre las diferentes estrategias interpretativas en cualquier esfuerzo de reflejar la historia en general. 6. Las razones para escoger entre una u otra perspectiva histórica son, en última instancia, estéticas o morales más que espistemológicas.

7. La visión científica de la historia representa sólo la preferencia por una modalidad de conceptualización histórica, un basamento estético o 
moral, pero donde la justificación epistemológica aún permanece sin establecerse. (xi, xii)

Hayden White ofrece en Metahistory un bosquejo de las categorías metodológicas empleadas para estudiar la historiografía en sus elementos constitutivos. Considera que es útil, inicialmente, distinguir entre lo que llama elementos "primitivos" y "no primitivos" de la historia. Define a los elementos primitivos de la historia como aquellos en los que "las huellas del pasado" son preparadas para la construcción de la historia dentro de una forma narrativa. White asume que lo que no tiene forma, como lo sublime del pasado, no puede ser apropiado directamente, no puede ser representado plenamente, pero sí puede ser interpretado textualmente a través de sus huellas históricas como archivos, reliquias, etc. El autor Ilama a esas huellas históricas las "memorias históricas relativamente no procesadas". Lo primero que tienen que hacer los historiadores, de acuerdo con White, es convertir esas memorias en historia, organizar los datos que poseen en una crónica y después en narraciones históricas.

El autor de Metahistory postula que los historiadores realizan un acto poético en el cual ellos prefiguran el campo histórico y constituyen éste como el dominio en el que ellos tienen las teorías específicas que explican lo que realmente pasó allí, a lo cual Ilama prefiguración. En la conclusión de Metahistory, White señala: 
I have suggested that a given historian will be inclined to choose one or another of the different modes of explanation, on the level of argument, emplotment, or ideological implication, in response to the imperatives of the trope which informs the linguistic protocol he has used to prefigure the field of historical occurrence singled out by him for investigation. I have suggested, in short, an elective affinity between the act of prefiguration of the historical field and the explanatory strategies used by historian in a given work. $(427)$

Este acto de prefiguración puede tomar un número de formas que White toma de la tradición interpretativa desde Aristóteles hasta la más reciente desarrollada por Vico, y también de modernos lingüistas y teóricos literarios. Estas formas se corresponden con los cuatro tropos del lenguaje poético: metáfora, metonimia, sinécdoque e ironía. De acuerdo con la teoría de White el tropo dominante determinará la base metahistórica de la obra histórica. White sintetiza lo anterior a través de cinco niveles de conceptualización de la historia: crónica, historia, modo de intriga, modo de argumento y modo de implicación ideológica.

El autor sitúa las crónicas y las historias para referirse a los elementos primitivos de los informes o relaciones, pero ambos son parte de un proceso de selección y arreglos de datos de la memoria histórica 
no elaborada con la intención de hacer esa memoria algo más comprensible a un tipo de audiencia en particular. Al respecto, White señala:

I begin by distinguishing among the following levels of conceptualization in the historical work: (1) chronicle; (2) story; (3) mode of emplotment; (4) mode of argument; and (5) mode of ideological implication. I take "chronicle" and "story" to refer to "primitive elements" in the historical account, but both represent processes of selection and arrangement of data from the unprocessed historical record in the interest of rendering that record more comprenhensible to an audience of a particular kind. (Metahistory 5)

La obra histórica representa un intento de mediatización entre lo que White Ilama campo histórico (archivos, cartas, relaciones, reliquias, memoria histórica sin procesar, documentos) y el público.

El proceso de escribir la historia, según White, está basado en un trabajo de interpretación de categorías y subcategorías: Elementos primitivos.

1. huellas

2. crónicas

3. historia 
Elementos "narrativos" no primitivos

4. formismo

5. organicismo

6. mecanicismo

7. contextualización

Intriga, que incluye los siguientes modos:

8. romance

9. comedia

10. tragedia

11. sátira

Ideología, que incluye los siguientes modos:

12. anarquismo

13. conservadurismo

14. radicalismo

15. liberalismo

Tropos del lenguaje poético:

16. metáforas

17. metonimia

18. sinécdoque

19. ironía

De acuerdo con White los historiadores comienzan a darle forma a las huellas del pasado transformándolas en crónicas. Una crónica, es 
para el autor, un determinado número de sucesos y personas que tuvieron que ver con el orden temporal en que éstos ocurrieron. Las crónicas tienen un final abierto, no tienen principio, ni final lógico. Las crónicas simplemente empiezan cuando los historiadores como cronistas las inician y concluyen cuando ellos las terminan.

Las historias, sin embargo, son diferentes. Sobre esto White piensa que las crónicas toman forma de historias por arreglos posteriores de los sucesos del pasado donde los sucesos se convertirán en los componentes de un gran espectáculo, el cual ya es pensado que tenga un comienzo, un desarrollo y un final:

Historical stories trace the sequences of events that lead from inaugurations to (provisional) terminations of social and cultural processes in a way that chronicles are not required to do. Chronicles are, strictly speaking, openended. (Metahistory 6)

Las historias tienen una forma discernible, aún cuando ésta sea la imagen de un caos, que separa los sucesos contenidos en él, de aquellos sucesos que pudieran haber aparecido en una crónica.

La medida de cuanta invención puede haber al pasar una crónica a la forma de historia depende del procedimiento, al menos en la etapa temprana, teniendo en cuenta que Hayden White define la historia como un discurso narrativo en el cual hay tanto inventado como encontrado. 
La diferencia entre una crónica histórica y una historia reside en el hecho de que los historiadores "encuentran" los sucesos mientras que los escritores de historias inventan la forma.

La compresión de la historia en el sentido tradicional, de acuerdo a la obra de White, no facilita la comprensión de que la historia también forma parte del discurso historiográfico. La transformación de los sucesos de una crónica en una historia ocurre con el arreglo de algunos de estos sucesos en lo que se ha tenido en cuenta la importancia jerárquica de los mismos, lo cual no quiere decir que los sucesos no hayan ocurrido, pero que en la historia esos sucesos pasaron de la manera que el escritor hizo que pasaran:

The same event can serve as a different kind of element of many different historical stories, depending on the role it is assigned in a specific motific characterization of the set to which it belongs. (Metahistory 7 )

El escritor trabaja con la verdad pero con la verdad de la ficción o de la imaginación como componente de la creación literaria.

Existe una diferencia entre lo que Hayden White denomina elementos primitivos (huellas, crónicas y cuentos) y la novela o narrativa. Es dentro de tres áreas que White piensa que la historia se transforma en narraciones históricas. Éstas son en primer término, la explicación por 
intriga, la explicación por argumento y la explicación por implicación ideológica.

Explicar el significado de la historia es lo que White denomina "explicación por intriga". En otras palabras, es la manera que una secuencia de sucesos toma forma en una novela o narrativa. "Emplotment is the way by which a sequence of events fashioned into a story is gradually revealed to be a story of a particular kind"(Metahistory 7). Para cambiar una historia que tiene ya su secuencia a novela, necesita primero que se cree la intriga, después codificado; y porque los sucesos del pasado no tienen en sí un argumento para que sea contado, entonces es necesario la producción de un argumento la cual resulta arbitraria. Todos los sucesos de la historia y la crónica puedeni crear una intriga de innumerables maneras narrativas. White considera que "a given historian is forced to emplot the whole set of stories making up his narrative in one comprehensive or arquetipical story form" (Metahistory 8). Los historiadores, si quieren que sus historias se conozcan, tienen que ser narradores con resonancia cultural.

La segunda área donde White considera que la historia se transforma en narrativa histórica es "la explicación por argumento". El autor considera que es posible distinguir en esta área cuatro tipos de modos: el modo formista, el modo organicista, el modo mecanicista y el contextualismo. White piensa que él ha identificado los cuatro tipos 
básicos para la explicación de un argumento y que muchas veces existirá una afinidad entre cualquier argumento y el modo de intriga usado.

Estos modos no han disfrutado de igual autoridad entre los historiadores reconocidos profesionalmente en la disciplina desde que ésta se academizó en el siglo XIX, como afirma White:

...., any of these four models of explanation might be used in a historical work to provide something like a formal argument of the true meaning of the events depicted in the narrative, but they have not enjoyed equal authority among the recognized professional practitioners of the discipline since its academicization in the early nineteenth century. (Metahistory 19)

Por ejemplo, entre los historiadores académicos los modos formistas y contextuales han venido siendo los ortodoxos. Los modos organicistas y mecanicistas han sido, en cambio, los menos afortunados en la historia y la filosofía de la historia. La razón de esta circunstancia, no es, según White, epistemológica, sino ideológica.

La tercera área que considera para la transformación de la historia en narrativa histórica es la que denomina "explicación por implicación ideológica". White plantea que existe un componente ideológico en todo relato histórico sobre el pasado: 
a given historian's emplotment of historical process or way of explaining it in a formal argument need not be regarded as a function of his consciously held ideological position. (Metahistory 24).

Aun aquellos historiadores que profesan que sus trabajos no están permeados por ideología alguna, son también ideológicos, porque todo rechazo es el resultado de una ideología. Para White, toda historia está, permeada por determinadas implicaciones ideológicas.

El autor cree que toda historia es afectada ideológicamente y que no existe nada que pueda servir de árbitro entre las diferentes interpretaciones de los procesos históricos. White está interesado en la ideología no sólo porque permite juzgar el grado y extensión de un conflicto desde el punto de vista ideológico en la historia sino porque también indica cómo las consideraciones de tipo ideológico en la historia entran dentro de los intentos del historiador para explicar los campos históricos.

La historia no es vista por White como una ciencia, ya que aquélla no tiene un lenguaje técnico, ni un lenguaje con sistema específico de terminología, con significados estipulados para elementos lexicográficos, ni con especificas reglas sintácticas, ni una determinada gramática, como ocurre con la química o la física. A los historiadores no les queda otra alternativa que escribir el pasado a través de una lengua que trabaja 
metafóricamente y convertir el pasado en algo familiar, usando las figuras de la oratoria. Lo único que tenemos para darle vida al pasado son los tropos figurativos.

White puntualiza que toda narrativa histórica presupone caracterizaciones figurativas de los sucesos que intenta representar. Al resumir las ideas de White sobre los tropos, se puede decir que White piensa que antes que los historiadores analicen las huellas, datos, crónicas, ellos prefiguran el campo tropológico. De esta manera, la visión que el historiador nos dará sobre uno u otro aspecto del pasado será siempre problemática y establecida tropológicamente.

La nueva novela histórica en Hispanoamérica, a partir de la publicación de la novela El Mundo alucinante, empieza a alejarse de la rigurosa documentación y recreación de la Historia basada en los textos canónicos y ha iniciado una nueva corriente que se adscribe al modo narrativo conocido como metaficción historiográfica. Las novelas históricas que se vinculan a este modo narrativo son obras que reflexionan sobre sí mismas y sobre el proceso de producción y recepción del texto literario. Los personajes y acontecimientos en estas novelas cuestionan las pretensiones de objetividad del discurso histórico. Esta nueva narrativa se ha producido simultáneamente a la consolidación de una nueva filosofía de la historia. La metaficción historiográfica es considerado como una manifestación del postmodernismo. En las nuevas 
novelas históricas que se enmarcan dentro de la ficción postmodernista no existen verdades históricas. ${ }^{14}$ Las verdades son cuestionadas, porque son vistas como construcciones sociales determinadas por la ideología dominante y el discurso del poder. 


\section{NOTAS}

' Seymour Menton en su libro La nueva novela histórica de la América Latina, 19791992. México: Fondo de Cultura Económica, 1993. (38) declara a la novela de Alejo Carpentier El reino de este mundo como "la primera verdadera nueva novela histórica".

2 Jiconténcalt según señala el crítico Alexis Márquez Rodríguez se parece más a la novela de Alfred de Vigny Cinq Mars (1826) que a las novelas de Walter Scott. En Cina Mars el autor ya coloca los personajes históricos en el primer plano, por el contrario en las novelas de Walter Scott los personajes históricos son secundarios. Ver Barrientos 13.

${ }^{3}$ Uslar Pietri, en El camino de El Dorado, supo convertir en una novela la rebelión de los marañones. En esta novela el autor regula la información mediante la elección de un punto de vista restrictivo.

${ }^{4}$ Seymour Menton, como ya he mencionado, es quien propone que con la publicación de la novela El reino de este mundo de Alejo Carpentier se inicia la nueva novela histórica hispanoamericana. Sin embargo, Juan José Barrientos difiere de Menton cuando plantea en su libro Ficción- historia. La nueva novela hispanoamericana: "para él la renovación comenzó con El reino de este mundo, mientras que para mi arrancó con El mundo alucinante" (23).

${ }^{5}$ Roland Barthes. Francia, 1915-1980. Renombrado crítico y ensayista, puede decirse que su obra ha trascendido notablemente esta caracterización inicial, teniendo en cuenta sus considerables aportes y la influencia ejercida sobre diversas esferas del conocimiento contemporáneo. Así, desde su formación en letras clásicas y tomando la múltiple herencia de la lingüística, el estructuralismo, la psicología y el marxismo, Barthes ha elaborado uno de los cuerpos conceptuales más ricos, personales y fecundos de nuestra época.

${ }^{6}$ En el ensayo El desamparado humor de Reinaldo Arenas Roberto Valero analiza lo carnavalesco, según Baktín, y como la crítica contemporánea a manejado el concepto a partir de la consideraciones del teórico ruso. Valero al respecto señala:

En principio me parece aceptable, siempre y cuando no se tome el marco teórico y se le aplique sin tomar en consideración el universo particular de Arenas [...] Lo carnavalesco, según Bakhtín, es la destrucción simbólica de lo oficial, de la autoridad, una renovación de formas, de estilos de vida, donde prevalecen la irreverencia, la libertad y cuya técnica al lector le producen la experiencia humorística. Por una parte el mensaje lo alegra, es un mensaje humorístico, pero también percibe un sentimiento de frustración o dolor que produce dicha experiencia humorística: el efecto desolador. (39-40)

${ }^{7}$ Los novelas históricas anteriores a El mundo alucinante (1969) como El reino de este mundo (1949) y El siglo de las luces (1962) han ido siendo descartadas como modelos a partir de la renovación que inicia Arenas del género iniciándose la actual tendencia de la nueva novela histórica enmarcada dentro de la historiografía postmodernista y la metaficción historiográfica. 
${ }^{8}$ En "La novela histórica hispanoamericana en el debate postmoderno" Nialls Binns afirma lo siguiente:

La metaficción historiográfica emprende una vuelta crítica al realismo de la novela histórica premoderna, instalando pero luego subvirtiendo sus presupuestos. No es una vuelta nostálgica e idealizada al pasado, como afirman muchos detractores de los postmoderno, ni una negación o recuperación del pasado en nombre del futuro [...] sino una $<$ presentificación>> problemática y un diálogo con el pasado. (161)

9 Nos referimos aquí al "modernismo internacional" y no al "modernismo hispanoamericano", dos movimientos que no tienen mucho que ver. También resulta problemático el estudio del postmodernismo en la literatura hispanoamericana porque, como bien señala Juan Navarro en Archival Reflections muchos latinoamericanistas: look with suspicion upon any attempt at connecting their own literary tradition to that of the United States, arguing that history of economic and cultural domination stands in the way of any positive interaction between the two regions. Americanists and Latin Americanists in the United States seem more concerned with establishing the uniqueness of their respective cultures than with initiating a dialogue that would allow for an understanding of these cultures beyond their own limited, nationalist contexts.

The field of postmodernist historical fiction in the Americas is particularly problematic in this respect. Because Latin American literature does not always conform to the models of Western literary history, most Hispanists have been reluctant to deal with the issue of postmodernism. Moreover, given its use of a highly subjective and relativistic epistemology, postmodernist fiction is considered to be at odds with the notion of historical consciousness. As a consequence, existing studies of postmodern fiction tend to read like decontextualized primers, dealing mainly with formal features and relying strictly on US literature for example. Latin American texts are either excluded from their studies or mentioned solely as exotic illustrations of a theory built upon US or European models. (2)

${ }^{10}$ También Fermín Févre en su libro Modernidad y postmodernidad en el arte : El término postmoderno ha sido empleado para tantas cosas que resulta muy difícil acotarlo. Además, muchos aspectos de esos significados son tan contradictorios y distantes que no es fácil unirlos" (69).

"Una de las maneras de entender el postmodernismo es como una categoría espiritual, un Kunustwollen o manera de hacer. Desde esta perspectiva se trataría de un concepto metahistórico. Toda época tendría su postmodernismo. En postmodernismo así concebido no tiene una demarcación cronológica, no se refiere a una época determinada. Otra manera de entender el postmodernismo es adjudicándole una relación cronológica, sucediendo al modernismo. Concebido de esta manera, se trataría de un proceso histórico, a partir del moderno en el cual pierden vigencia determinados aspectos y acentos y surgen otros que privilegian una nueva percepción de la realidad. Esta acepción de la postmodernidad va unida a la crisis de los sistemas totalizadores, a su descentralización y a una heterogénea amplitud en le campo de las significaciones.

${ }^{12}$ Jean Fraçois Lyotard tuvo una militancia en grupos de izquierda heterodoxa, situándose dentro de un marxismo crítico. En los años setenta, principalmente a partir 
de una evolución que lo lleva a alejarse definitivamente del marxismo, comienza a desarrollar un pensamiento original, nutrido sin duda de sus propias experiencias de vida. Por una parte, advierte la pérdida de valor, y consecuentemente de autoridad, de los "grandes relatos" marxistas que quiebran en él un soporte de legitimidad. Aparece entonces el tema del deseo, en el sentido que tiene para Nietzsche. El deseo de la búsqueda de lo imposible, según el concepto de Lacan. Lyotard encuentra una situación equivalente en el terreno del capitalismo, donde el deseo, concebido como un sistema de cargas energéticas, deriva produciendo una notoria pérdida de su fuerza libidinal. Observa que hay una falta de identificación en la generación joven con los "valores" de la sociedad consumista, manifestando más bien un escepticismo prácticamente nihilista. El pensamiento de Lyotard alcanza su mejor síntesis y una confluencia de todo su proceso transformador en su obra La condición posmoderna, que trata sobre la situación del saber en las sociedades más desarrolladas.

${ }^{13}$ Influido por Lacan. Bachelard, Blanchot, Dumézil, Barthes, amigo intelectual y político de Deleuze, Focault pertenece a la generación de jóvenes franceses que, con las armas de Marx, Freud, Nietzsche y Heidegger, intentan "olvidar" a Hegel y elaborar ese "olvido".

${ }^{14}$ Según Brian MacHale las novelas postmodernas se caracterizan por sus preocupaciones ontológicas. Según MacHale explica la novela histórica postmoderna no procura suprimir la violación de los límites ontológicos al representar personajes y acontecimientos "ficticios" al lado de otros del mundo histórico real. Por el contrario, según el mencionado autor, la novela histórica tradicional si procuraba suprimir estas violaciones esquivando contradicciones con la historiografía oficial; evitando anacronismos culturales y creando un mundo ficticio compatible con el mundo real. Ver MacHale. Postmodern Fiction. 87- 88. 
Segundo capítulo: La nueva novela histórica novomundista en Hispanoamérica

\section{EL DESCUBRIMIENTO Y LA CONQUISTA EN LA NOVELA HISPANOAMERICANA}

Desde el surgimiento mismo de la novela en Hispanoamérica ésta se interesó por el tema del "descubrimiento" y la conquista de América. Estos dos acontecimientos históricos permitieron a los escritores condensar en una misma narración la relevancia de lo sucedido y el carácter épico tanto de la conquista española como de la resistencia americana ante los invasores. Ya en el siglo XIX algunas novelas hispanoamericanas tratan de la conquista y destrucción de la América precolombina. La conquista, fundamentalmente, fue el asunto histórico de las novelas románticas. Debemos recordar que Enriquillo de Galván recrea los primeros años de la colonia en Santo Domingo y trata de la rebelión de un cacique aborigen contra los abusos del gobierno colonial a principios del siglo XVI. En dicha novela aparecen personajes históricos como Diego Colón y el fraile dominico Bartolomé de las Casas. Otras novelas se propusieron narrar la conquista de otras regiones americanas. Entre estas novelas están las que tratan de la conquista de Yucatán, como por ejemplo La cruz y la espada (1866) de Eligio Ancona. Dentro del escenario de la conquista del imperio incaico se encuentran las novelas 
El último rey de los muiscas de Jesús Silvestre Rozo, publicada en 1856 y Huayna Cápac de Felipe Pérez, publicada el mismo año.

El tema de la conquista en la narrativa decimonónica se caracteriza por tener como tema central acontecimientos históricos documentados en otros textos canónicos del discurso histórico y por tener como protagonistas a personajes históricos cuya existencia fue anterior a la ficción, como por ejemplo, Cortés, Cuahtémoc y Moctezuma. Estas novelas se aproximan mucho a lo que se denomina biografías noveladas.

Como señala Roberto González Echevarría, existe una interrelación esencial y primigenia entre historia y ficción en Hispanoamérica: "Latin American history is to Latin American narrative what the epic themes are to Spanish literature: a constant whose mode of appearance may vary, but which is rarely absent." (Myth and Archive 6) Desde sus orígenes la narrativa hispanoamericana ha estado condicionada por una obsesión con el mito y particularmente con su propia historia. En otras palabras, desde sus inicios la narrativa hispanoamericana comenzó un proceso literario de continuas refundiciones textuales a nivel metaliterario e historiográfico.

Sin embargo, si es cierto que el interés por la historia en la narrativa hispanoamericana lo podemos situar desde sus orígenes y que el tema del "descubrimiento" y de la conquista ya había sido tema de novelas desde el siglo pasado, no es menos cierto que en los últimos 
treinta años parece haber incrementado el interés histórico de los novelistas hispanoamericanos por el tema. Este interés y las actuales estrategias interpretativas de metadiscursos (post) estructuralistas han producido una serie de novelas que podríamos llamar del "redescubrimiento". Algunas de las novelas históricas hispanoamericanas sobre los viajes de descubrimiento de españoles y portugueses y la conquista de América son:

1. Maladrón. Miguel Ángel Asturias. (Guatemala, 1969)

2. Terra Nostra. Carlos Fuentes. (México, 1975).

3. Daimón. Abel Posse. (Argentina, 1978)

4. El arpa y la sombra. Alejo Carpentier. (Cuba, 1979)

5. El mar de las lentejas. Antonio Benítez Rojo. (Cuba, 1979)

6. Lope de Aguirre, príncipe de la libertad. Miguel Otero Silva. (Venezuela, 1979)

7. Crónica del descubrimiento. Alejandro Paternain. (Uruguay, 1980)

8. Río de las congojas. Libertad Demitrópulos. (Argentina, 1981)

9. El entenado. Juan José Saer. (Argentina, 1983)

10. Los perros del paraíso. Abel Posse. (Argentina, 1983)

11. Una lanza por Lope de Aguirre. Jorge Ernesto Funes. (Argentina, 1984)

12. Memorias del nuevo mundo. Homero Aridjis. (México, 1988) 
13. Maluco. Napoleón Baccino Ponce de León. (Uruguay, 1990)

14. Colombina descubierta. Alicia Freilich (Venezuela, 1991)

15. Vigilia del Almirante. Augusto Roa Bastos. (Paraguay, 1992)

16. El largo atardecer del caminante. Abel Posse. (Argentina, 1992)

Los personajes históricos que más han sido recreados en estas novelas centradas en torno al tema del "descubrimiento" y la conquista son Cristóbal Colón y Lope de Aguirre. Las vidas de ambos personajes están rodeadas de aventuras, ambiciones, intrigas y controversias que atraen a los escritores hasta la actualidad. Una aproximación a estos personajes a través de la historial oficial nos revela la existencia de muchos vacíos que la historiografía tradicional no ha podido satisfacer o que simplemente ha querido ignorar. La nueva novela histórica intenta llenar estos vacíos cuando reconstruye la existencia de tales personajes pero también existe en las reconstrucciones una reflexión y un cuestionamiento implícito de muchas de las "verdades" aceptadas por el discurso historiográfico tradicional.

\section{COLÓN: ENTRE LA CONTROVERSIA Y LA ESPECULACIÓN}

Los novelistas, que se han visto atraídos por el personaje de Cristóbal Colón, escriben sobre el Colón capitán y almirante varado en el Mar de los Sargazos, en medio del océano Atlántico, como nos lo presenta, por ejemplo, Augusto Roa Bastos en Vigilia del Almirante. Más 
que el Colón esclavista les interesa el soñador, el embaucador viajero por las cortes de Lisboa y de Castilla. Así nos los presenta Carpentier en El arpa y la sombra. Abel Posse en Los perros del paraíso nos lo describe como un hombre de cierta bondad e ingenuidad y nos sitúa en América con la idea de haber retrocedido a los tiempos medievales y de haber alcanzado el Paraíso terrenal.

Se ha escrito mucho sobre Cristóbal Colón, en español, por autores españoles o hispanoamericanos. También se ha escrito sobre Colón en otros idiomas desde el comienzo del siglo XIX hasta el presente. Los datos esenciales apenas varían de unas a otras alternativas de construcción a pesar de las controversias y vacíos históricos existentes sobre la vida de este personaje histórico. La mayoría de los datos conocidos se tienen más o menos por ciertos y poco se discute sobre ellos. Sin embargo, hay detalles que son motivo de disputas pero no afectan lo fundamental: el esquema de su travesía por el mundo mediterráneo. Podríamos mencionar entre los detalles que son motivo de polémicas los siguientes: si era italiano o hijo de familia española, si era cristiano viejo o judío converso, si aprendió a navegar con respetables navegantes o entre corsarios, si sabía hablar castellano cuando llegó a Lisboa o lo aprendió allí, qué libros leyó, qué significaban las iniciales cabalística de su firma, por qué huyó de Portugal, cómo obtuvo el favor de los franciscanos de La Rábida y convenció a los Reyes Católicos. Al no 
existir aportes fundamentales y convincentes, las especulaciones favorecen más a la narrativa que al discurso histórico oficial. Los puntos oscuros de Colón no varían su condición de ser el hombre que encontró un Mundo Nuevo pero si favorece mucho a la novela histórica, la cual nos presenta matices, del personaje de los que el discurso histórico tradicional no se ocupa.

Uno de los primeros autores que desmitifica a Colón fue Vicente Blasco Ibáñez. En 1928, el mismo año de su muerte, escribió En busca del Gran Khan. Blasco Ibáñez acierta en sacar partido a los hallazgos y disertaciones de las recopilaciones de Madariaga y Morrinson así como los estudios de De Llollis, Harrisse, Thacher, Vignaud y otros especialistas. Con exactitud, recorre toda la información conocida sobre Colón, con ponderación, sin exageraciones, ni descuido u omisiones. Blasco Ibáñez "consigue un amenísimo ensayo novelado, repleto de digresiones de honda factura didáctica a lo Víctor Hugo, expuestas de manera ágil, directa, sencilla, nada barroca, y por ello efectiva en lo que interesa" (Usable González 277). Cristóbal Colón es presentado como un vagabundo hábil con aspiraciones de grandeza:

Una leyenda formada después de la muerte de Colón nos lo ha presentado durante tres siglos como un genio superior a todos sus contemporáneos, sólo comparable a una montaña aislada en el centro de un desierto, esta concepción 
romántica y falsa no puede ser más opuesta a la realidad. (Blasco Ibáñez III. 1252)

Blasco Ibáñez evita adoptar la posición maniquea que había imperado en la novela hasta el siglo XVIII. Alejándose de las posiciones canónicas, el autor nos presenta la España imperialista de los Reyes Católicos, y a Isabel como una usurpadora del trono castellano, que correspondía por derecho a doña Juana, hija reconocida del rey Enrique IV.'

La primera novela dentro de la corriente de la nueva novela histórica hispanoamericana que gira sobre el tema del descubrimiento y el personaje de Cristóbal Colón es El arpa y la sombra (1979), la cual estudiaremos con detenimiento en otro capítulo. La novela de Carpentier trata de mostrarse fiel al discurso histórico tradicional huyendo, al mismo tiempo, de la construcción hagiográfica, exagerada y laudatoria. Carpentier se distancia en relación con el protagonista central, lo que le permite hablar del él desde una perspectiva crítica sin denigrarlo pero tampoco aparentando ser su admirador apasionado. Según Carpentier plantea en su conferencia "Sobre El arpa y la sombra", hubo dos escritores franceses, Paúl Claudel y León Bloy, que decidieron dignificar en tal grado al personaje de Cristóbal Colón que terminaron por inventárselo de principio a fin. Propusieron una mística y mítica, digna de alcanzar la gloria de los santos; un emisario de los cielos que abrió para Occidente, no una nueva ruta comercial, sino un escondido e inmenso 
mundo lleno de almas necesitadas de salvación. Porque Colón fue ante todo, según estos autores, el Christo ferens, el portador del Cristo. ${ }^{2} \mathrm{q}$ Los perros del paraíso (1987) de Abel Posse, otra de las novelas centrada en el tema de la conquista y la figura de Colón, la cual estudiaremos también en otro capítulo, tiene en común con El arpa y la sombra el mismo proyecto de desmitificación del personaje histórico de Cristóbal Colón. En ambos textos, el Almirante aparece como un hombre arribista, sin ideales nobles ni humanitarios que sólo se movía por sus propios intereses y los de su familia. Pero hay un detalle, entre otros, que distingue ambas novelas: en el texto de Carpentier, el personaje del Almirante toma parte en la despoblación de las Antillas, en la novela de Posse adopta una postura de pseudo- pasividad cómplice. El Colón de Los perros del paraíso, hamacado bajo una ceiba (que tiene por centro del Paraíso Terrenal), ni siquiera asiste en persona a la imposición forzada del sistema mercantilista europeo, metáfora elemental de sus múltiples ausencias descubridoras respecto del campo de la colonización americana.

En el marco de la nueva novela histórica hispanoamericana la tercera novela centrada en el tema del descubrimiento y con el personaje de Colón como protagonista se encuentra Vigilia del almirante (1992) de Augusto Roa Bastos, escrita en Tolousse (Francia), es parte de un 
compendio de eficaz documentación en torno a los hechos históricos relatados:

En realidad el novelista paraguayo no hace casi otra operación que glosar con un estilo literario muy pulcro las principales noticias, episodios y conflictos que más o menos cualquier historiador tiene presente a la hora de remitir, para una biblioteca de difusión general, un corto esbozo de la vida y personalidad de descubridor. (Usable González 292)

Resulta evidente que Roa Bastos se documentó en textos canónicos como los de Hernando Colón, Salvador de Madariaga y Juan Manzano Manzano y, según el mismo autor reconoce, fue asesorado por modernos y "eminentes historiadores" expertos en la vida de Colón. ${ }^{3}$

No obstante, aunque el autor de Vigilia del Almirante haya consultado las fuentes tradicionales del discurso histórico y haya sido asesorado por historiadores contemporáneos, el texto de Roa Bastos es una creación fabuladora con muchos de los parámetros y contenidos de los ensayos de teoría literaria. Roa Bastos no intenta con su obra ser un vehículo de transmisión fidedigna de los datos y acontecimientos históricos. Cada texto es la modificación de un código anterior, de una idea precedente y de anteriores elaboraciones. Ningún autor tiene la razón absoluta sobre un hecho o conjunto de hechos porque nunca 
existe una causa única, sino varias; muchas de las cuales escapan a nuestro conocimiento.

En Vigilia del Almirante el autor no engaña, reconoce que su novela es una recreación de las andanzas del Almirante, un eslabón más de una historia interminable, como nos plantea el propio texto:

Esta buena gente (sus lectores) se ha quemado los ojos, despepitado el ánima, dejado la vida en la penosa y larga tarea de cinco cientos años para averiguar quién era yo. Cosa que me muero sin saberlo, ¡loado sea Dios!, y que nadie sabrá jamás. Cada individuo es infinito y misterioso como el universo mismo, y ante cada uno la imaginación tiembla sin saber por dónde comenzar para entenderlo y menos aún en qué punto terminar. Por lo cual ninguna historia tiene principio ni fin y todas tienen tantos significados como lectores haya. (Roa Bastos 370)

En Vigilia del Almirante se mezclan la creación fabuladora con la documentación de textos canónicos sobre el tema del descubrimiento. En esta novela tanto el acontecimiento como el protagonista son tratados con ambigüedad. ${ }^{4}$

Al aproximarse el lector a esta novela dudará acerca de la historicidad de lo narrado y podrá verse incitado a una confrontación con los materiales del discurso histórico tradicional (los escritos de Colón y 
otros textos canónicos) y con los estudios académicos, para después volver a leer la novela con más criterio. Una segunda lectura de Vigilia del Almirante hace que el lector tome una conciencia más plena de la complejidad de esta novela, que le aparece intrincada, trabada en varias perspectivas y en varios niveles de lectura.

Si leemos la nota introductoria del autor podemos ver que indica retrospectivamente un triple designio:

1. "recuperar la carnadura del hombre común, oscuramente genial que produjo sin saberlo, sin proponérselo, sin presentirlo siquiera, el mayor acontecimiento cosmográfico y cultural registrado en dos milenios de historia de la humanidad." (1 11$)$

2. "contar en lengua de hoy su historia adivinada; una de las tantas de posible invención [...]" (11)

3. "imaginar su presencia en presente; o mejor aún, en el no tiempo, libremente [...]" (1 11$)$

Esto se completa luego, cuando Roa Bastos destaca que, de manera general, todo autor escribe "ese libro que casi siempre no oculta sino un trasfondo secreto de su propia vida; el libro irrepetible que surge, cada vez, en el punto exacto de confluencia entre la experiencia individual y la colectiva, en la piedra de toque de un personaje arquetípico" (12). Es decir, apunta a una dimensión simbólica o mítica del protagonista del libro y al mismo tiempo llama la atención sobre el aspecto 
profundamente personal del libro. De acuerdo con esto, Vigilia del Almirante se desarrollaría alrededor de dos ejes semánticos: la biografía histórica, inevitablemente relativa y deliberadamente subjetiva, y la imaginación simbólica, entre interpretación colectiva "mítica" y personal. En otras palabras, podemos encontrar tres niveles de sentido, interrelacionados: biográfico-histórico, simbólico, y autobiográfico.

Analizando el nivel biográfico - histórico, de entrada, se puede afirmar que la figura de Colón es desmitificada y condenada. Aunque es cierto que esta novela nunca nombra a Colón como tal y recurre a cierta "polifonía", no cabe duda sobre la función referencial del llamado "Almirante" ni sobre el referente histórico; ${ }^{5}$ en cambio la polifonía es modesta (oímos principalmente las voces del "Almirante" y del narrador, el cual hace también de intermediario para otras voces o puntos de vista, como los cronistas, un amigo historiador de indias...) y si bien contribuye a producir una imagen compleja por calidoscópica, no promueve un auténtico dialogismo. En esta novela no sólo se impone el punto de vista del narrador, sino que todos, incluso el mismo Almirante, conspiran para imponer un duro juicio.

El famoso Descubridor aparece en Vigilia del Almirante como el gran "Encubridor", el encubridor de un "encubrimiento" generalizado y un auténtico criminal, "el iniciador del holocausto americano," (Roa Bastos 194) asistido por un grupo de miserables en carabelas llevando 
nombres de meretrices. ${ }^{6}$ El llamado "Descubrimiento" se nos presenta como una "una orgía bestial en todos los sentidos que duró siglos" (69). Roa Bastos se complace en recalcar hechos que empañan la gloria del Almirante.

Tales hechos podrían resumirse esquemáticamente de la siguiente manera: Colón llegó tarde; ${ }^{7}$ Colón sobrepuso a lo que veía el mundo de sus fantasías; Colón no se adentró en el Continente de manera que sólo fue el "precursor absoluto de los conquistadores, colonizadores y encomenderos que serán los verdaderos descubridores del Orbe Nuevo $(203,204)$, y sobre todo, Colón es el iniciador y el responsable de la esclavización de los indígenas:

Si esas tierras que voy a descubrir no tienen oro, lo cual las haría inútiles y pérdidas, de seguro tendrán gente. Se puede la prender a toda ella y traella como esclavos y consumilla en las minas, y aun vendella a buen precio en las granjerías de la mesma España y aun del resto de Europa. (178)

En Vigilia del Almirante se recuperan pero también se manipulan todos los recursos de la historiografía crítica del descubrimiento, su autor deconstruye la figura de Colón en cuanto a persona, desarrollando incluso una estrategia desmitificadora que combate los diversos aspectos de la tradición celebradora. ${ }^{8}$ 
Si prestamos atención a lo que hemos llamado "nivel biográfico histórico", cabe concluir que el aspecto biográfico obedece más a una intención pragmática (adoptar una posición con respecto a la conmemoración del V Centenario de la empresa descubridora de América) que a una meditación a partir de lo que se sabe, o una invención intuitiva con intención de aproximación a la "verdad" histórica. Hay un juicio que preexiste a la novela y que ésta amplifica. El proceso culmina en el último capítulo ("Las cuentas claras") donde el mismo Almirante declara su culpabilidad histórica, e insiste en la obligación moral de una reparación.

Las múltiples lecturas que ofrece Vigilia del Almirante nos permite acercarnos al texto a través de su nivel simbólico. Lo que más llama la atención, por su carácter simbólico en un sentido más amplio, son las especulaciones mitológicas y escatológicas del Almirante. El autor se complace en evocar las conjeturas del Almirante, y sobre todo infiltra la voz de éste, atribuyéndole reflexiones de talante simbólico inverosímiles o incluso anacrónicas. ${ }^{9}$ Sobre todo, este discurso simbólico encaja perfectamente dentro de la perspectiva simbólica que determina fundamentalmente la novela. Se observa en el texto un proceso incesante y múltiple de simbolización que transfigura al descubrimiento y su protagonista. Empieza por supuesto con la sustitución del nombre "Colón" por la designación "Almirante", que permite el paso de lo 
particular a lo general: el Almirante llega a adquirir un valor alegórico al tiempo que representa el tipo de Colonizador. ${ }^{10}$ Se trata de una simbolización que se basa en una interpretación previa de tipo moral.

Resulta interesante otra modalidad simbolizadora: la que consiste en la identificación del "descubrimiento" con paradigmas míticos. Vigilia del Almirante no sólo retoma sino que amplifica las referencias míticas, paganas o cristianas, que fueron las de Colón: Tifis, Jasón, Jesús, Moisés, pero también la Edad de Oro, el Paraíso. En Vigilia del Almirante:

la visión mítica es ahistórica, aspecto que no parece ser casual ni secundario (sobre todo teniendo en cuenta que algunos procedimientos confirman semejante visión, así el anacronismo sistemático, que suprime las distinciones temporales para convertir el tiempo en un espacio homogéneo) y relacionarlo con este hecho: leyendo a la manera de Bachelard uno se da cuenta de que toda la novela manifiesta un profundo horror al Tiempo (o a la muerte) y correlativamente un deseo virulento de negar el Tiempo, desplegando todo el abanico a la vez rico y clásico, de los ensueños antitemporales. (Lefebre Robin - 545)

El horror al Tiempo no destruye la interpretación mítica del descubrimiento que aquélla promueve porque corresponde a una 
auténtica meditación del autor y porque este tipo de interpretación coincide con toda la tradición del pensamiento mítico.

Vigilia del Almirante es en parte una reflexión del tiempo y del devenir y también una meditación sobre el descubrimiento de América. Acontecimiento que, como dice Todorov:

anuncia y funda nuestra identidad presente; aun si toda fecha que permite separar dos épocas es arbitraria, no hay ninguna que convenga más que marcar el comienzo de la era moderna que el año de 1492, en que Colón atraviesa el océano Atlántico. (15)

Y este tema no sólo supone una interpretación de la personalidad y motivaciones de Colón, sino una reflexión acerca del enfrentamiento histórico entre las identidades europea e indígena así como, "del descubrimiento que el yo hace del otro" (Todorov 13), o sea la alteridad. La novela de Roa Bastos no elude ninguno de estos aspectos, y resalta de manera notable la heterogeneidad de las culturas indígenas, ${ }^{11}$ pero se concentra en la meditación acerca del ser del Almirante, y correlativamente en un ¿quién soy? Ahora, podríamos detenernos y ver en la interpretación del autor acerca de su identidad propia un análisis del nivel autobiográfico de Vigilia del Almirante. 
En la nota introductoria de la novela el autor se presenta como "mestizo de dos mundos", al tiempo que indica el carácter afectivo de la relación del mestizo con la figura del Almirante-Padre, "imaginar su presencia.... con amor odio filial...." (11). La novela no desarrolla explícitamente estos aspectos pero está claro que la naturaleza y la condición de mestizo del autor determinan la imaginación del descubrimiento y en particular el partidismo.

Desde un puno de vista general se puede considerar que todo el libro tiene una dimensión autobiográfica. En Vigilia del Almirante se expresan con igual intensidad, a propósito del "descubrimiento", el yo discursivo y el yo imaginativo. El autor invade el discurso del Almirante y hemos observado que desarrolla de manera oblicua una meditación muy personal acerca del Tiempo y la Muerte; también resulta evidente como para imponer una visión mítica que refleja a la vez un pensamiento y una afectividad propios. La lectura de la novela no nos permite por supuesto valorar los posibles autodescubrimientos del autor, pero sí percibir el compromiso autobiográfico, en el sentido de una biografía espiritual y afectiva inherente al texto.

\section{LOPE DE AGUIRRE: EL CONQUISTADOR REBELDE}

La nueva novela histórica novomundista no ha dado el mismo trato a Colón que a Lope de Aguirre. Ambos personajes son polémicos y 
juzgados, pero en la nueva novela histórica la figura de Colón es desmitificada y condenada. Colón es presentado como hombre arribista, encubridor de verdades, hombre sin ideales nobles ni humanitarios. Existe un alejamiento de la construcción hagiográfica y laudatoria de la historiografía tradicional. Sin embargo, la figura de Lope de Aguirre en la nueva novela histórica se ensalza, despierta admiración. Lope de Aguirre se idealiza hasta el punto de ser presentado como rebelde libertador.

La rebelión de Lope de Aguirre contra su superior inmediato y contra el mismo rey de España en medio de la selva amazónica, es uno de los acontecimientos más extraordinarios que nos dan a conocer las crónicas sobre esa etapa oscura de la conquista y la colonización de América. Este personaje de la historia ha inspirado a varios novelistas europeos e hispanoamericanos quienes se han tratado de reconstruir todo lo concerniente a aquella aventura.

Una de las primeras creaciones literarias de las aventuras de Lope de Aguirre es Las inquietudes de Shanti Andía, novela de Pío Baroja la cual guarda entre sus imaginativas páginas una clara referencia a este personaje de la historia. El escritor hace de su protagonista un descendiente directo del caudillo marañón, de quien asegura, por las ficticias memorias de Domingo de Cincunegui, que había nacido en el primer tercio del siglo XVI, y era vizcaíno. Después de sucesivas traiciones y revueltas en las que participó, Lope buscó amparo en 
Omagua. Sublevó a sus compañeros, obligándolos a intervenir en el asesinato del gobernador Ursúa y de su amante, Inés de Atienza, hija del conquistador Blas de Atienza:

A la cabeza de sus hombres, subyugado por el terror (ahorcó a ocho que no le parecían bastante fieles), bajó por el Amazonas y recorrió, después de meses y meses, la inmensidad del curso de este enorme río y se lanzó al Atlántico.

No contaba Lope más que con barcas apenas útiles para la navegación fluvial; pero él no reconocía obstáculos y se internó en el océano. Lope de Aguirre era todo un hombre.

En los fragmentos anteriores de la novela de Pío Baroja resaltan dos ideas que resultan casi una constante en toda la novelística sobre Lope de Aguirre. La primera, se admite el carácter temperamental de Lope, que anduvo imponiendo siempre su lealtad por el miedo, cometiendo crímenes y abusos, en espera del apoyo incondicionado de su tropa. $Y$ segundo, Lope de Aguirre despierta sentimientos de admiración y orgullo. En Las inquietudes de Shanti Andía se entrevé el destino guiñolesco de las hazañas de este personaje, cuando Shanti augura: 
El leer aquellas aventuras de Aguirre me producía un poco la impresión que produce a los niños "Guiñol" cuando apalea al gendarme y cuelga al juez. A pesar de sus crímenes y de sus atrocidades, Aguirre, el loco, me era simpático. (67)

Hay en estas líneas algo de tragicomedia esperpéntica que varias décadas después Abel Posse desarrollará en su novela Daimón, en donde Lope de Aguirre y su tropa acaban por convertirse en personajes guiñolescos.

La primera obra íntegra dedicada a Aguirre la escribió Ciro Bayo, publicada en 1913 con el título Los marañones (leyenda negra del Nuevo Mundo) constituye:

una novelita endeble, una sencilla lectura dramatizada de la famosa crónica de Francisco Vázquez [...] a la que sólo se agregan leves digresiones paisajísticas sobre la selva, el clima, la vegetación y la fauna, es decir, todo lo que las fuentes testimoniales pasan por alto, no carece de cierta valía propia, pues le cabe el mérito de poner el dedo en la llaga del tremendo dislate de acomodo social que motivó la revuelta. (Usable González 324)

La novela refleja el descontento general en la tropa que había sobrevivido a las guerras civiles entre pizarristas y almagristas en el virreinato del Perú donde los cargos públicos, las haciendas y las riquezas (oro, plata y esmeraldas) se repartían muy desigualmente; con frecuencia, resultaban 
destinados a acallar voces amigas (los protegidos del virrey), desdeñando aquéllas que en verdad lo merecían después de llevar años pacificando las tierras.

Dentro de la narrativa hispanoamericana el primer novelista que recrea al personaje de Lope de Aguirre es Arturo Uslar Pietri en su novela El camino de El Dorado (1947). Esther Smith en "La novela en la historia: un encuentro metaficcional" plantea que:

Uslar Pietri frente al reconocimiento de sus pares que junto a Carpentier lo consideran iniciadores de la novela histórica contemporánea en Latinoamérica, [...] se mantiene firme en su aseveración de su falta de interés por la misma. Busca al personaje histórico, lo ficcionaliza hasta lograr de él un personaje de novela en sus vivencias, en sus desazones, en sus luchas; pero sobre todo busca lograr un Hombre. (189) En las novelas de Uslar Pietri no es la historia el centro de sus pensamientos, sino el aspecto trágico del hombre en la historia. En su novela El camino de El Dorado el personaje de Lope de Aguirre es irónico y no provoca en el lector regocijo ni complicidad, sino la reserva, el distanciamiento, el miedo, la intranquilidad y hasta la refutación. La actitud del narrador, en todo momento omnisciente, es distante, fría y desentendida del personaje central. ${ }^{12}$ La novela está relatada con una exposición tradicional que respeta la hilación cronológica de los sucesos. 
Julio Cortázar escribió, en 1948, una reseña sobre El camino de El Dorado. En ella subraya el tono esquemático de sencillo relato de aventuras: "Los hombres se mueven, luchan, sucumben, traicionan, sin que en ningún momento se dé al lector la posibilidad de ahondar en esas corazas y esos petos castellanos" (135). Uslar Pietri sigue, al pie de la letra, las relaciones testimoniales, reservándose únicamente la inventiva en lo que concierne a aquello que se echaba de menos en todos los escritos del siglo XVI: las descripciones del río Marañón, de sus riberas, de su fauna y vegetación. "Más feliz con el paisaje que con las almas. Uslar Pietri alza a primer plano los ríos, las barcas, las sabanas y las islas; toda la obra está impregnada de esa convivencia con lo telúrico que signa la mejor novelística americana" (Cortázar 135-136). El autor crea descripciones que no estaban aún en el idioma de las crónicas del siglo XVI. Son los cuadros descriptivos los que hacen preferir, para una lectura amena y sosegada, el texto del autor venezolano.

Miguel Otero Silva es otro autor hispanoamericano que escribe una novela centrada en el tema de la conquista y que tiene como personaje a Lope de Aguirre. La novela de Otero Silva Lope de Aguirre, príncipe de libertad (1979) pertenece por la fecha de su publicación y por la intención del autor a lo que hemos venido llamando nueva novela histórica. Otero Silva utiliza la caracterización de un personaje histórico, en este caso conocido, polémico, juzgado, y elabora una nueva forma de 
interpretar la vida de Lope Aguirre y abre el camino a nuevas construcciones sobre el tema y personajes de la conquista de América.

La novela de Otero Silva inserta otro modo de visualizar a Lope de Aguirre y trata de develar nuevas intenciones y propósitos que la novela histórica tradicional no desarrolló. En esta novela, Lope es estudiado y explicado desde una perspectiva humana. En la novela histórica tradicional más cercana al discurso histórico oficial Lope de Aguirre es visto solamente como el eje de unos episodios históricos sangrientos. Otero Silva infunde en esta novela otro modo de visualizar las diferentes aristas que presenta el personaje de Lope. El protagonista de su novela aparece como santo y diablo, luz y tinieblas, protector y verdugo, pero ante todo y ante todos, rebelde libertador, profeta de la independencia americana, héroe intranquilo de un largo sueño de pasado y presente.

En Lope de Aguirre, al centrar su autor, la atención en el personaje mencionado, también se acerca a otros temas que no sólo comportan gran importancia sino que intentan explicar la conducta de este hombre que, en determinada perspectiva, fue el resultado de la controvertida época que le tocó vivir. En esta novela se entremezcla lo histórico, lo documental, la ficción y la pasión libertaria.

Desde el inicio de la novela el autor introduce al lector en un ámbito sangriento derivado de una acción punitiva que castiga un acto de rebeldía. De allí deriva lo que habrá de ser, a lo largo del recorrido 
anecdótico, el contenido rebelde de su personaje central: Lope de Aguirre. Otero Silva, se remonta hasta la juventud de Lope en la villa de Oñate, donde habitaron sus ancestros más próximos. El mismo protagonista nos narra los sucesos, nos informa de cómo su madre le confirió nombre en honor a su padre rebelde, Lope de Araoz a quien, por irreverencia a la persona del emperador Carlos, le fue arrancada la lengua en la picota. El conflicto entre los Aguirre y los Austria viene de mucho antes de descender aquel navarro Pedro de Ursúa por el Huallaga.

La novela de Otero Silva establece las características del ser humano Lope de Aguirre, quien hizo de la venganza un modo de acción y llevó su vida tratando de descubrir traiciones y desapegos. Pero esa rebeldía está muy bien explicada por la obra. Lope, según el texto de Otero Silva, no trata sólo de conseguir un poder temporal o propiciar alzamientos. Su idea era más amplia y su ideal no era otro que el de supeditar su intimidad rebelde a una causa:

No capitanes y oficiales, nuestra salvación no está en escribir papeles de humillación que a ninguno engañarán, sino en vender nuestras vidas rebeldes, en volver al Perú no en busca de perdones inaccesibles sino de amigos igualmente descontentos como nosotros, aquellos millares de hombres disgustados porque nunca le fueron gratificados su mal trato de los virreyes y oidores. Volvernos al Perú y unirnos a ellos 
para tomar esa tierra como nuestra y defenderla de nuestros enemigos....eso es lo que nos conviene. (Otero Silva 173-74)

En Lope de Aguirre Otero Silva rescata la figura del conquistador en favor de una actitud libertaria. Trata de equilibrar, en lo posible, la controversial personalidad de Lope de Aguirre y así como se ciñe a lo histórico, de la misma manera, manifiesta su incondicional simpatía por un personaje a quien considera como símbolo de la libertad.

Abel Posse, uno de los escritores más destacados de la nueva novela histórica hispanoamericana, también se vio a atraído por la figura controvertida de Lope de Aguirre al cual convierte en personaje protagonista en su novela Daimón (1978). Esta novela es una particular diacronía que asume, al menos, quinientos años del pasado del continente americano. Planificada como un largo collage comprende una variedad de registros temáticos como la política, la sociedad, la economía, la literatura, la canción, las artes y el cine. La novela no se limita a un momento histórico determinado, sino que convirtiendo en espectro inmortal a Lope de Aguirre, lo hace caminar a través de diferentes espacios y momentos de América Latina. Por su gran importancia dentro de la nueva novela histórica, las novelas de Posse y Carpentier serán analizadas en los capítulos siguientes. 


\section{OTRAS (SUB)VERSIONES DEL DESCUBRIMIENTO Y LA CONQUISTA}

Una de las novelas más interesantes sobre el tema del descubrimiento y la conquista es El mar de las lentejas (1979) de Antonio Benítez Rojo. ${ }^{13}$ En esta novela se recuentan cuatro momentos claves de los primeros años de la conquista y colonización de América. En su recuento, Benítez Rojo altera la secuencia cronológica de los hechos históricos y alterna episodios de sucesos diferentes sin que se pierda la unidad de lo narrado, lo cual logra a través de la articulación de las propias rupturas y coincidencias que impulsan los hechos. Usando el caos cronológico como estrategia narrativa, el texto logra la creación de una versión o (sub) versión de la historia estableciendo un diálogo entre el presente del narrador y el pasado narrado.

No existe en esta novela un personaje protagónico único como en las novelas hasta ahora estudiadas, sino que comparten el escenario narrativo cuatro criaturas literarias. La novela comienza con Felipe II en su lecho de muerte. Por los pensamientos del rey moribundo desfila la historia de su imperio y la decadencia de su poder absoluto en América con la derrota de la Armada Invencible. En el segundo capítulo aparece Antón Baptista, el único personaje totalmente ficticio de la novela. A través de este capítulo el autor traslada al lector al segundo viaje de Colón y a los hechos turbulentos de la conquista y la colonización de América. Otros personajes destacados en la novela son el hidalgo de 
sangre limpia y viejas normas de conducta, llamado Pedro Valdés; un comerciante (hijo de genovés naturalizado en España, judío converso) Pedro Ponte. Un quinto personaje, que aparece apenas, el marino Hawkins, es mantenido en la sombra durante muchas páginas cuidadosamente. Estos cinco personajes se mueven con independencia en la novela.

El texto de Benítez Rojo se basa en hechos documentados por el discurso histórico oficial, pero al ser recontados en el ámbito de la ficción, la imaginación manipula tanto los hechos históricos como la interpretación y la documentación de esos hechos. En El mar de las lentejas "se evidencia un constante juego de desplazamientos y de cancelamientos de un discurso por otro (Cuervo Hewitt 464) y un rico juego intertextual a través de otros textos como órdenes, cédulas y documentos coloniales que llenan los vacíos textuales con el fin de crear un complejo diálogo entre el documento histórico y la ficción.

En la novela de Benítez Rojo se recompone la historia del Caribe a través de cartas, omisiones, y fragmentos de la chismografía de la época, documentada en informes vengativos, registros, y relaciones manipuladas por intereses particulares. El mar de las lentejas dice su autor:

....es una novela que tiene mucho del texto no escrito por mi y que yo fui a buscar con la esperanza de que eso 
constituyera un origen de la latinoamericanidad....Mi

propósito inicial fue, repito, el darle a esos textos autoridad, pero luego me di cuenta de que eso era un disparate; y que esa gente confrontaba el mismo problema que estaba confrontando yo; que, en definitiva, lo que ellos estaban escribiendo era lo mismo que estaba escribiendo yo,... un texto manipulado por mis deseos... (Cuervo Hewwitt 470)

En El mar de las lentejas hay un proceso doble de re-escritura y relectura de los textos históricos tradicionales. El comentario de Benítez Rojo sugiere una lectura de su propio texto en la que se propone un discurso doble cuyo objetivo es desplazar un discurso por otro. Y en el que se establece que el deseo que manipula los hechos, es el mismo juego discursivo del deseo que mueve la re- escritura de la novela.

El proceso de doble re-escritura y re-lectura de los textos históricos tradicionales que se encuentra en El mar de las lentejas sugiere, como ha observado Michel Foucault, que "lo que se encuentra en el comienzo histórico de las cosas, no es la identidad inviolable de sus orígenes; es la disensión" (Foucault "Nietzche...."142) El origen, observa Foucault, "yace en un lugar de inevitable pérdida, el punto donde la verdad de las cosas corresponde a la verdad del discurso, o sea a la fidelidad de sus propios elementos; el lugar de la articulación fugaz que el discurso, una red de reglas, códigos e interpretaciones, ha oscurecido 
y finalmente perdido" (Foucault, El orden del discurso 143). El juego discursivo en El mar de las lentejas se articula a través de una narrativa que describe, recuenta, documenta, copia y transforma, en un afán de apropiarse de esos discursos fundadores para cancelarlos como autoridad y mito porque éstos, lejos de describir el origen de nuestra identidad, la encubren.

Otra novela histórica que plantea una visión revisionista del descubrimiento es El entenado de Juan José Saer (1983). En ella Saer relata una búsqueda circular basada en las memorias ficticias de un grumete español. El entenado, es en parte, la historia de este joven español que vive diez años en cautiverio entre los indios Colastinés después de haber sobrevivido a un ataque desastroso. Eventualmente el protagonista regresa a España donde decidió, a los sesenta años de edad, escribir sus memorias.

En El entenado se recrea una imaginaria cosmogonía indígena que tiene algo de idealista y existencial. La novela refleja una aparente preocupación antropológica bajo la cual subyace en realidad una reflexión sobre la estructura de deseo, tanto en la cultura indígena como la europea. Una angustia incierta que parece acosar a los españoles se asienta también en los indígenas por la intuición de estos últimos de que el universo es insustancial. 
Los indígenas, al igual que los europeos, se sienten expulsados de un Paraíso originario y en una búsqueda de seguridad en su inestable realidad acuden a un acto de canibalismo ritual cada año, donde comen carne humana para volverse "un poco más nítidos, más enteros y sentirse menos enredados en la improbabilidad chirle de las cosas" (Saer 129). El ritual termina cada año en un estado de profunda depresión colectiva porque, intuye el narrador, el canibalismo encubre en realidad el soterrado deseo de comerse a sí mismos: "el objeto en apariencia más alejado de su deseo, es decir ellos mismos, era, y ellos lo sabían; sin representárselo con claridad sin dudas, la verdadera causa de sus expediciones" (Saer 130). Los indígenas en el texto de Saer no pueden saciar su hambre, porque es su misma carne la que comen, por lo que no alcanzan a satisfacer su deseo. El objeto deseado está adentro del que busca, y es esa interioridad la que le cierra el acceso al Paraíso deseado. La novela de Saer se basa en un "supuesto" suceso histórico que ha llegado a nuestros tiempos a través de una leyenda que cuenta que la expedición de Juan de Solís en la zona de Río de la Plata, en 1516, fue atacada por indios antropófagos quienes mataron a éste y a casi toda la tripulación. El único sobreviviente del ataque es identificado como Francisco del Puerto. Diez años después la expedición de Sebastián Gaboto por el valle del Paraná encontró a este perdido grumete, el cual pudo regresar a España. ${ }^{14}$ Al seleccionar Saer este suceso de la conquista 
para su novela, El entenado recrea un suceso histórico que ya había sido en cierta medida novelado y envuelto en la leyenda.

Saer provoca una lectura paródica que cuestiona la objetividad del discurso histórico oficial. Como puntualiza Linda Hutcheon en su descripción de la "metaficción historiográfica", Saer incorpora el discurso del pasado para destacar la pregunta "of how the intertext of history, its documents and traces, get incorporated into an avowedly fictive context, while still somehow retaining their historical documentary status" (Hutcheon "Postmodern Paratextuality and History" (302-3). La ficción postmodernista selecciona estos modelos paratextuales como espacios privilegiados para establecer un diálogo crítico con discurso histórico tradicional.

Otra novela que se inscribe dentro de lo que Linda Hutcheon ha Ilamado "metaficción historiográfica" es Maluco de Napoleón Baccino Ponce de León. Maluco relata la historia del viaje de Magallanes desde la perspectiva del bufón de la flota, quien muchos años después le escribe al rey Carlos $\mathrm{V}$ para que éste le otorgue una pensión en reconocimiento a sus servicios. La novela de Baccino adquiere el formato de una extensa carta a un lector implícito, Carlos V, escrita por Juanillo Ponce, el protagonista de la historia.

Maluco es una novela en la que se registran diferentes niveles de intertextualidad. Estos niveles remiten al lector a diferentes voces que 
hacen que el texto esté en continuo movimiento y un constante diálogo consigo mismo y otros tipos de discursos. En esta novela "la cita, la alusión, la parodia y otros aspectos intertextuales se combinan para formar un polifonía que aprovecha las infinitas posibilidades de la creación novelesca a través del lenguaje" (Vich 405). Maluco permite la participación activa del lector quien puede asumir la propuesta del texto de jugar con la historia y con las fronteras entre realidad y ficción.

El dialogismo en la novela de Baccino Ponce de León se puede ver en dos niveles. El primero es el que se da a partir del diálogo que se establece con la Historia; específicamente con el Primer viaje en torno del globo de Antonio Pigafeta. La crónica de Pigafeta, uno de los miembros de la expedición, constituye el armazón histórico que sostiene el relato. Y el fenómeno de la intertextualidad en este primer nivel está orientado hacia una reescritura ficcional de la Historia que no toma muy en serio la autoridad de un texto tradicional como el de Pigafeta. El diálogo intertextual que se establece entre la escritura de la historia que hace Pigafeta y la lectura y reescritura de la misma que hace Baccino Ponce de León conforman la variedad y riqueza discursiva que se encuentra en Maluco.

El segundo nivel de dialogismo es el que entabla y mantiene la novela con otros textos literarios, como por ejemplo, con Cien años de soledad. En Maluco el narrador proviene de la tradición picaresca 
española pero el ambiente en que se sitúan los hechos nos remite al mítico Macondo de la novela de García Márquez. También es fácil advertir una actitud paródica al examinar la manera que se introduce como intertexto la metáfora con la que Jorge Manrique inicia sus "Coplas a la muerte de su padre". La metáfora de Manrique es caricaturizada al presentarse dentro de un discurso prosaico que la frivoliza.

La versatilidad en el manejo de la intertextualidad se pone de manifiesto cuando otra es la actitud con la que se introduce como intextexto un fragmento del "Romance del Conde Arnaldos" lo cual, en la novela de Baccino, recitaba Juanillo Ponce como parte de su repertorio de bufón. Por otro lado, uno de los más evidentes diálogos intertextuales de Maluco es el que se establece constantemente con Don Quijote. Son notables los paralelismos entre los personajes de la novela don Hernando y Juanillo con don Quijote y Sancho. También se establecen diálogos con intertextos provenientes de la poesía de César Vallejo y Charles Baudelaire. La intertextualidad, el dialogismo enriquecen el carácter polifónico de esta novela donde el narrador, el texto, los intertextos y el lector son voces que se relacionan pero que se hacen escuchar con independencia.

Las novelas históricas novomundistas mencionadas, sobre todo las escritas en los últimos treinta años, demuestran el interés actual de los novelistas por el tema del descubrimiento y la conquista. Estas novelas 
que podríamos Ilamar del "redescubrimiento" son en parte producto del interés por el tema así como el resultado de las actuales estrategias interpretativas de metadiscursos (post) estructuralistas. La nueva novela novomundista en Hispanoamérica intenta a veces reconstruir y otras rescatar la existencia de personajes y sucesos que la historiografía tradicional ha visto desde otra perspectiva o simplemente ha ignorado. Estas novelas llenan ciertos vacíos que la historia tradicional no ha podido satisfacer. La nueva novela novomundista es, por lo tanto, una reflexión sobre el descubrimiento y la conquista, y, a la vez, un cuestionamiento del discurso historiográfico oficial. 


\section{NOTAS}

'Ver el apéndice, a modo de epílogo, de En busca del Gran Khan titulado "El misterio de Colón", en el cual Blasco Ibáñez subraya el aspecto ególatra de la personalidad de Colón: En realidad, sólo creía en él mismo y sólo sintió interés por los consanguíneos que llevaban su nombre. Era potencialmente, un experimentado embaucador, decía saber mucho más de lo que en verdad dominaba: Como hombre de Ciencia, no conoció más que lo en su época era del dominio vulgar. Basaba sus teorías en manuales enciclopédicos al alcance de todo el mundo y en novelas de viajes. Muchos de los que escuchaban sus planes sabían más que él. Pero, a pesar de todo, de sus incómodos y terribles defectos, era un personaje de una dimensión única, ciertamente fuera de lo habitual: Colón no fue un sabio ni santo. Fue simplemente un hombre extraordinario, dotado de gran imaginación y firmísima voluntad, con alma de poeta y avaricias de mercader, audaz unas veces y otras prudentes en exceso, hasta el punto de dejar sin terminación las más de sus exploraciones; genial en muchas de sus concepciones y en otras obcecado y testarudo de un modo incomprensible.

${ }^{2}$ Ver la conferencia de Alejo Carpentier, "Sobre el arpa y la sombra".

${ }^{3}$ En Vigilia del Almirante Augusto Roa Bastos escribe: "Agradezco sincera y muy especialmente a los eminentes historiadores Francisco Morales Padrón, Consuelo Varela, Juan Gil y a Juan Manzano Manzano (cuyo libro Colón y su secreto me confirmó lúcida y visionariamente la existencia real del predescubridor Alonso Sánchez, verdadero co-protagonista de esta Vigilia); expreso mi gratitud al profesor y legislador italiano Paolo Emilio Taviani. Sin todos ellos y una larga lista de estudios de la historia colombina, que no cito (citar es omitir, decía Borges) esta historia fingida no hubiese podido ser imaginada ni escrita." (378)

${ }^{4}$ En la nota introductoria de Vigilia del Almirante Roa Bastos se refiere al descubrimiento como "el mayor acontecimiento cosmográfico y cultural [...]" (11) Es decir el autor no asume la perspectiva propugnada por Edmundo O'Gorman en La invención de América donde O'Gorman sugiere que América no fue descubierta sino inventada porque fue una necesidad del hombre europeo. El hombre en Europa se sentía prisionero del mundo medieval regido por las ideas del geocentrismo y la escolástica con visiones jerárquicas de un universo perfecto, incambiable aunque finito porque era el lugar de la Caída.

${ }^{5}$ El texto remite de forma evidente a la vida de Colón (no importa aquí que sea con alteraciones e invenciones), parafrasea los escritos de éste, alude a su nombre; además, lo que Gérard Genette Ilama "peritexto" (en particular la nota introductoria y los "Reconocimientos", así como el texto de la contraportada) y el metadiscurso que acompañó la publicación son explícitos.

${ }^{6}$ La tesis del "encubrimiento" remite a una tradición de la historiografía "revisionista". Véase Leopoldo Zea, "12 de octubre de 1492 ¿Descubrimiento o encubrimiento?"

7 "La existencia de poblaciones y culturas venidas desde el Asia y la Polinesia demuestra in situ quiénes han sido los verdaderos descubridores." (64:cf1 85)

${ }^{8}$ Roa Bastos, manipula la historia y desmitifica la figura de Colón, siguiendo el ejemplo de Alejo Carpentier en El arpa y la sombra. 
${ }^{9}$ Por ejemplo: La parte en sombras del cosmos es la medianoche primordial. Se agranda sin pausa a medida que el universo se expande" (25-26). La simbolización múltiple y ostensible de la arena, en la página 123, es improbable aunque sugestiva.

${ }^{10}$ En su presentación de Vigilia del Almirante en la Universidad Complutense de Madrid (parcialmente reproducido en El País (10-14-92), Roa Bastos declaró que esperaba haber contribuido a formar una "conciencia crítica", al tiempo que evocaba "la inevitable hecatombe de pueblos que los imperios producen, como fue el caso en la propia América precolombina de los aztecas, incas y mayas [...]"

1 Pero es cierto que también tiende a perpetuar la perspectiva edénica (mitos del buen salvaje y del Paraíso Terrenal) que había sido inaugurada y luego renegada por Colón.

${ }^{12}$ Uslar Pietri nunca ensalzó la rebelión de Aguirre. Al parecer cuando el autor empezó a escribir su novela, Lope de Aguirre permanecía en la memora colectiva venezolana como figura del Malo. Robin Lefebre en su artículo "Historia y ficción: la figura de Aguirre" documenta la existencia en Venezuela, con anterioridad a la novela El camino del Dorado, de abundantes obras donde la imagen de Aguirre es la del Tirano. En 1936, escribió un cuento Red, el fuego fatuo, donde insinúa que sólo era un sanguinario egoísta de mujeres a las que pronto hacía enviudar. Aguirre es uno de los personajes que deshacen la Historia, que en vez de obligarla a avanzar mediante la puesta en práctica de iniciativas importantes, la sabotea, al maquinar una dictadura acorde con los intereses de los encomenderos, en contra de las leyes de Indias, y opuesta, igualmente, al espíritu filantrópico de los héroes posteriores de la Independencia de Hispanoamérica.

13 "El mar de las lentejas" o "la mer de lentille" fue la denominación que el cosmógrafo francés Guillaume le Testu dio a las islas del Caribe: Puerto Rico, la Española, Cuba, Jamaica y la Margarita. El cosmógrafo cometió una equivocación fonética, entre "Antille" (Antilla) y "Lentille" (lenteja), en el primer mapa de la zona del Caribe en el que esta región aparece por primera vez con otro nombre que no fuera Mar del Norte.

${ }^{14}$ Los historiadores argentinos Vicente Sierra y Eduardo Madero mencionan a Francisco del Puerto como un miembro de la tripulación que acompañaba a Juan de Solís. Madero reconoce que tomó el nombre de Francisco del Puerto de diversos documentos. Él confirma que la mayor parte de la información fue tomada de las crónicas de Antonio Herrera, (Década 2da, libro primero. Capítulo. 1.) única crónica en que aparece el nombre de Francisco del Puerto. Aparentemente, el diario de Juan de Solís se perdió un tiempo después que Herrera terminara su obra. Según Madero, la información sobre Francisco del Puerto y la catástrofe de la expedición de Juan Solís se encuentra en "Asiento inédito del libro manual del doctor Sancho de Matienzo, tesorero de la Casa de Contratación de Sevilla 1516"(54). El historiador aclara que no existe ningún documento en que el grumete español cuente su historia. 
Tercer capítulo: La nueva novela histórica de Alejo Carpentier

\section{EL REINO DE ESTE MUNDO (1949)}

Alejo Carpentier es una de las figuras más importantes en la asimilación de la vanguardia europea en Hispanoamérica. Su conocimiento de la música lo convierte en uno de los pioneros del movimiento afrocubano, cuyos comienzos se manifiestan antes en ese arte que en la literatura. Su íntimo conocimiento de Europa y del francés le permiten servir de mediador entre las corrientes culturales europeas e hispanoamericanas. "Todas las ventajas que su doble origen le brindan las paga Carpentier con la ambigüedad cultural que sus críticos le achacan, y que él proyecta, tanto en sus múltiples viajes como en la temática del desarraigo que atraviesa toda su obra" (González Echevarría, "Alejo Carpentier" 127). La búsqueda de la identidad americana será una constante que se manifiesta con particular insistencia y complejidad en la obra de Carpentier.

La Hispanoamérica de los años cuarenta a la que ingresa Carpentier es, para los intelectuales y artistas que como él habían vivido la vanguardia europea, ya sea en Europa misma o desde el Nuevo Mundo, la Hispanoamérica del regreso y la re-inmersión. Con Carpentier regresan de Europa - sobre todo de Francia y España-, después de la caída de la República española, y con el comienzo de la Segunda Guerra Mundial, 
gran número de artistas e intelectuales hispanoamericanos, numerosos artistas e intelectuales europeos. Los años cuarenta son el período de la búsqueda de la conciencia americana, del esfuerzo por desentrañar los orígenes de la historia y del ser hispanoamericano para fundar sobre ellos una literatura propia, distinta de la europea.

Durante la década de los años cuarenta, Carpentier redacta dos libros: La música en Cuba (1946) y El reino de este mundo (1949) y todos los relatos con excepción de El acoso. La década de los cuarenta es la más prolífera de Carpentier, y en más de un sentido la más importante. Todos los relatos que Carpentier escribe en los años cuarenta parten de investigaciones históricas llevadas a cabo con motivo de La música en Cuba (1946). Estos relatos se caracterizan por su historicidad, por desarrollarse su acción en una época pasada, que se señala por trajes, costumbres, objetos, o a veces por incidentes pretéritos conocidos, cuando no por alusión directa a personajes históricos reconocibles.

Toda la ficción de Carpentier va a girar en torno a la biografía de un personaje que Carpentier rescata del olvido, con la excepción de Los pasos perdidos en que el biografiado es el propio Carpentier. La prosa de Carpentier que hasta ese entonces está llena de reflejos estilísticos de la extrema vanguardia, en los años cuarenta, se va despojando de esos recursos hasta convertirse en esa prosa añeja, arcaizante y barroca que lo distingue desde entonces: 
La ficción carpenteriana no será mera evocación de un pasado, sino que querrá ser un pastiche de esos textos en que se encierra la memoria hispanoamericana, repetición, re- elaboración textual en el sentido más concreto y tangible." (González Echevarría, “Alejo Carpentier” 133)

Carpentier inicia, según sugiere Seymour Menton, la transformación de la novela histórica.' A partir de la publicación de El reino de este mundo empezamos a encontrar un distanciamiento de la historia oficial mediante su reescritura paródica, así como una preocupación por el lenguaje: arcaísmos, pastiches y parodias.

De las obras escritas por Carpentier durante los años cuarenta, los relatos y El reino de este mundo son las obras que mayor interés encierran para la crítica. Mario Vargas Llosa considera que Carpentier alcanzó:

la maestría consumada, a partir de 1949, cuando apareció su primera obra maestra, El reino de este mundo, acaso la mejor de sus novelas y una de las más acabadas que haya producido la lengua española de este siglo. [...] Pocas veces, en la crítica latinoamericana, un trabajo de paciente erudición ha sido tan fecundo para iluminar el encaminamiento mediante el cual un escritor de genio 
saquea el mundo real, lo desmenuza y reconstituye con la palabra y la fantasía para ponerle una imagen literaria. (32)

También los críticos Roberto González Echevarría, Richard A. Young, Nury Raventós y Emma Susana Speratti-Piñero, entre otros, se han ocupado de esta novela.

En su trabajo de investigación Los Pasos hallados en El reino de este mundo, Speratti-Piñero demuestra que la novela es un "mosaico increíble" de datos históricos, mitológicos, religiosos, etnológicos y sociológicos recogidos por Carpentier en libros de viajeros, historiadores, correspondencias, artículos especializados, biografías, refundidos y organizados en un orden compacto para dar una versión literaria o ficticia de las luchas independentistas y de los primeros años de vida soberana de Haití. ${ }^{2}$ Speratti - Piñero prueba que prácticamente no hay en la novela un solo personaje (ni siquiera Ti Noel), ni un episodio, y aun detalle o motivo que no tenga raíces bibliográficas. ${ }^{3}$ La historia que cuenta parece mucho más cerca de lo legendario, lo mítico, lo maravilloso y lo fantástico que del mundo objetivo y la pedestre realidad. Pero esta impresión no solamente resulta de la historia que El reino de este mundo cuenta, sino, exclusivamente, de la astuta y original manera en que el narrador cuenta la novela.

El discurso del narrador, de palabras rebuscadas, es antagónico a la fingida espontaneidad y oralidad. Sobresale en el discurso escrito lo 
leído y premeditado, lo corregido y repensado. Pese a la impresión de un lenguaje fabricado, Carpentier es de una gran precisión a la hora de designar el objeto y describirlo, y de un extraordinario poder de síntesis. Su característica principal, además de la exactitud, es la "sensorialidad" lujosa, la manera como se las arregla para que la historia parezca entrarle al lector por todos los sentidos: la vista, el oído, el olfato, el sabor, el tacto.

El tiempo de El reino de este mundo es lento. El lector tiene la sensación de que el tiempo se ha detenido. Y esta sensación se debe a que cada capítulo tiene un tiempo propio, pero, entre capítulos, no hay flujo cronológico, continuidad anecdótica. La historia de la novela no avanza como el tiempo "real". Salta de un período a otro como si aquéllos no estuvieran enlazados en una secuencia, sino yuxtapuestos, conservando cada uno su autonomía temporal.

El reino de este mundo no es solamente una evocación del pasado sino un pastiche de otros textos que encierran la memoria hispanoamericana, repetición, re-elaboración textual en el sentido más concreto y tangible. La nueva novela histórica se preocupa por el lenguaje y la utilización de diferentes formas expresivas como el arcaísmo, el pastiche y la parodia. El pastiche es una de las formas expresivas que utiliza Carpentier en El reino de este mundo. Según Aínsa: "El lenguaje es la herramienta fundamental de la nueva novela histórica y acompaña su 
preocupada relectura del pasado, un modo de validarla literariamente" ("La reescritura de la historia" 26). El pastiche, junto al arcaísmo y la parodia, es uno de los procedimientos para la "reconstrucción" de la historia que realiza este tipo de novela.

En el prólogo a la primera edición del reino de este mundo, el propio Carpentier nos dice que en esta novela:

se narra una sucesión de hechos extraordinarios, ocurridos en la isla de Santo Domingo, en determinada época que no alcanza el lapso de una vida humana [...] [El] relato que va a leerse ha sido establecido sobre una documentación extremadamente rigurosa que no solamente respeta la verdad histórica de los acontecimientos, los nombres de personajes - incluso secundarios -, de lugares y hasta de calles, sino que oculta, bajo su aparente intemporalidad, un minucioso cotejo de fechas y cronologías. (8)

La novela reescribe acontecimientos históricos conocidos como la revuelta de Mackandal, la rebelión de Bouckman, la llegada de los colonos franceses a Santiago de Cuba a raíz de las convulsiones políticas de la isla vecina, las campañas del General Leclerc y el reinado de Henri Christophe. ${ }^{4}$ 
Si tomamos algunos de los acontecimientos más memorables narrados en el texto de Carpentier, nos damos cuenta que el procedimiento utilizado por el autor en la composición de la novela es el collage, la superposición de textos históricos. Prácticamente todas la escenas importantes del relato están tomadas de textos históricos. La historia que nos relata es constatable, documentable y podría aceptarse que ésta prácticamente se copia, se repite en su texto. El rigor documental e informativo caracteriza las novelas históricas de Carpentier en esta etapa.

Uno de los sucesos históricos que Carpentier reconstruye en su novela es el que tiene que ver con la legendaria figura de Mackandal. ${ }^{5} \mathrm{El}$ historiador Ricardo Pattee en su obra Haití pueblo afroantillano dice: Mackandal pertenecía a la plantación de Lenormand de Mézy, en el norte de la colonia. Hijo de jefe africano, se le había llevado joven de su hogar, en la costa de Guinea, como rehén, al norte de África, donde vivió entre musulmanes y adquirió algunas nociones de esta religión. Pasó a Saint Domingue como esclavo, y muy pronto se destacó entre sus compañeros por su viva inteligencia y descomunal audacia. Perdió una mano en un accidente de trabajo y, manco, se le destinó al cuidado del ganado. Decidió huir, y pronto reunió en torno de su persona un número considerable de esclavos, 
que veían en él un iluminado, un profeta, acaso un mensajero de quién sabe qué oscura divinidad africana. Utilizaba su conocimiento rudimentario de la botánica, y especialmente de las plantas venenosas, para matar el ganado, y no pocas veces a los propietarios. (69)

En El reino de este mundo, Carpentier recrea la visión de Mackandal presentada por Patte y la que otros historiadores como Dantés Bellegarde, Moreau de Saint- Méry, o Pierre de Vaissiere recogen en sus obras.

Alfred Metraux es otro historiador que da veracidad al suceso sobre el envenenamiento del ganado y de los colonos franceses en Haití. Metraux, en su obra Vodú, considera a Mackandal como "uno de los precursores de la independencia haitiana" (36) y sobre él dice:

había concebido el proyecto de echar a los blancos de Santo Domingo y de constituir un reino negro independiente. Su arma era el veneno. Exhortaba a sus partidarios para que hicieran desparecer por este medio a la gente de la "casa grande", a diezmar los obrajes y a exterminar el ganado. (36) Mackandal representa en El reino de este mundo el comienzo de la conciencia nacional.

El veneno o el papel político interpretado por el veneno transforma a Mackandal en leyenda hasta el momento del suplicio de éste en la plaza 
Mayor una vez que el esclavo fugitivo es capturado. Carpentier narra el final de Mackandal en el capítulo "El gran vuelo". Este suceso histórico está trabajado con recursos del realismo mágico. Dentro de un análisis tradicional podría verse como fantástico. Carpentier narra como Mackandal fue quemado vivo. ${ }^{6}$ Su narración está basada y documentada en lo acontecido el 20 de enero de 1758 en la Plaza Mayor de la que fuera entonces la capital de Haití. Historiadores como Moreau de Saint Mery, Gibbs Marshall, Ricardo Pattee y Alfred Metraux corroboran y documentan lo acontecido ese día.

Metraux asevera que Mackandal cuando lo condenaron a ser quemado vivo:

Hizo correr el rumor de que escaparía a las Ilamas bajo la forma de una mosca. La multitud que asistía a su suplicio pudo creer durante un momento que su profecía se iba a cumplir, pues los esfuerzos violentos que el dolor le obligaba a hacer arrancaron el poste en que estaba atado y cayó de bruces por encima de la gira. Un grito se levantó de la plaza: "Mackandal salvado". Se produjo un pánico, pero Mackandal atado sobre una tabla fue nuevamente arrojado a las llamas. Aunque su cuerpo fue incinerado muchos negros se negaron a creer que había muerto en el suplicio" (36) 
Metraux nos narra lo que es aceptado por el discurso tradicional historiográfico sobre este acontecimiento. En El reino de este mundo Carpentier también se atiene a lo que está documentado por los historiadores tradicionales pero no por eso el pasaje escrito por Carpentier deja de ser magicorrealista.

En su novela Carpentier nos narra que el pueblo haitiano se reunió en la Plaza Mayor para presenciar los actos de cremación de Mackandal:

Los amos interrogaron las caras de sus esclavos con la mirada. Pero los negros mostraban una despechante indiferencia. ¿Qué sabían los blancos de cosas de negros? En sus ciclos de metamorfosis, Mackandal se había adentrado muchas veces en el mundo arcano de los insectos, desquitándose de la falta de un brazo humano con la posesión de varias patas, de cuatro élitros o de largas antenas. Había sido mosca, ciempiés, falena, comején, tarántula, vaquita de San Antón y hasta cocuyo de grandes luces verde. (40)

Luego, señala Carpentier, que los negros sabían que:

En el momento decisivo, las ataduras del mandinga, privadas de un cuerpo que atar, dibujarían por un segundo el contorno de un hombre de aire, antes de resbalar a lo largo del poste. Y Mackandal, transformado en mosquito zumbón, 
iría a posarse en el mismo tricornio del jefe de las tropas, para gozar del desconcierto de los blancos. (40) Hasta aquí el autor ha creado dentro de la estructura de la novela, el ambiente propicio para la irrupción de lo insólito: la metamorfosis del personaje. El gobernador ordena que se inicie la cremación y:

El fuego comenzó a subir hacia el manco sollamándole las piernas. En ese momento, Mackandal agitó su muñón que no habían podido atar, en un gesto conminatorio que no por menguado era menos terrible, aullando conjuros desconocidos y echando violentamente el torso hacia delante. Sus ataduras cayeron, y el cuerpo del negro se espigó en el aire, volando por sobre las cabezas, antes de hundirse en las ondas negras de la masa de esclavos. Un solo grito llenó la plaza.

- Mackandal sauvé! (41)

Por supuesto esta forma de realismo mágico trabajada por Carpentier es diferente a la usada para narrar el envenenamiento del ganado. Aquí Carpentier se atiene a los hechos históricos y no podemos aceptar como hecho real o histórico la metamorfosis de Mackandal. Por lo tanto, la transgresión de la realidad reside en el pueblo que creía o necesitaba creer firmemente en esos poderes mágicos, sobrenaturales de Mackandal. 
Otro suceso histórico documentado por el discurso histórico tradicional y que Carpentier recrea en su novela es el de la aparición del espectro de Cornejo Breille, en el capítulo "Crónica del 15 de agosto". La recreación del suceso histórico está trabajada por Carpentier con una técnica de encubrimiento o camuflaje: la relación entre el dato insólito y la realidad histórica hay que buscarla a través de la transmutación de los hechos contados por el discurso tradicional. En otras palabras, detrás de un suceso inexplicable (como es la aparición del espectro de Cornejo Breille) se percibe una realidad corroborable, pero transformada en otra. El autor disfraza, transfigura el hecho creando una segunda realidad análoga en sus componentes esenciales a la primera.

Precisando los hechos históricos e indagando en los textos de historia de Haití, encontramos que Juan de Dios González era un sacerdote cubano que vino a sustituir al arzobispo de Haití Cornejo Breille. Huber Cole lo confirma, en su obra Christophe King of Haití, cuando nos dice que Christophe's "new archbishop, sucesor to the recently defunct Corneille Brelle, [is] a white Cuban named Juan Gonzalez" (253). Corneille Brelle había sido arzobispo de Haití por muchos años y, cuando cayó en desgracia con el gobierno de Christophe, éste "no lo hizo perecer en un calabozo de detención pública, lo dejó en el arzobispado [...] ordenó que tapiaran las puertas de una pieza de su apartamiento y le hizo servir una ración matinal de agua y de casabe; otros dicen que de 
pan. Ocho días más tarde el viejo sucumbió....." (Leconte 407). Ambos personajes históricos son recreados en El reino de este mundo para, a partir de una sucesión de datos reales y mediante una transmutación de los mismos, crear una situación magicorrelalista en su relato.

En el año 1814, siendo Cornejo Breille, arzobispo de Haití, fue obligado a oficiar una misa de réquiem. La misa era un plan macabro de Christophe, quien concibió dar al Coronel Medina, condenado a muerte por traición, un funeral de estado, con la presencia del prisionero aún vivo. El historiador Hubert Cole nos narra:

The church of Notre Dame was hung with funeral draperies. Medina was perched on a platform high enough for all the congregation to see him, with the empty coffin beside him. The archbishop, the aged Corneille Breille, conducted a requiem mass in the presence of the entire royal family. Members of the nobility, ministers of state, and packed throng of soldiers and civilians. (220)

Los paralelismos entre la misa de requiem celebrada por Corneille Breille en 1814, de acuerdo a los textos históricos canónicos, y la narrada por Carpentier en El reino de este mundo son obvios.

Veamos como Carpentier presenta, en el capítulo "Crónica del 15 de agosto", dentro de un ambiente aparentemente normal al rey 
Christophe y la familia real asistiendo a misa. Inmediatamente irrumpe en el relato lo sobrenatural:

De pronto, Juan de Dios González comenzó a retroceder hacia las butacas reales, resbalando torpemente sobre los tres peldaños de mármol. La reina dejó caer el rosario. El rey llevó la mano a la empuñadura de la espalda. Frente al altar, de cara a los fieles, otro sacerdote se había erguido, como nacido del aire, con pedazos de hombros y de brazos, aún mal corporizados...(106)

El nombre de Cornejo Breille se atravesó en la garganta de Christophe, dejándolo sin habla. Porque era el arzobispo emparedado, de cuya muerte y podredumbre sabían todos, quien estaba ahí, en medio del altar mayor [...] Juan de Dios se desplomó gimiendo a los pies de la reina. Henri Christopher, desorbitado soportó hasta el Rex tremendae majestaris. En ese momento, un rayo que sólo ensordeció sus oídos cayó sobre la torre de la iglesia, rajando a un tiempo todas las campanas. (106-7)

La referida misa, de acuerdo con los textos históricos canónicos como el de Hubert Cole, fue oficiada en 1814 por Cornejo Breille obligado por Henri Christophe. En el reino de este mundo, la misa de 1814 se 
transfigura y se torna más macabra aún, como se puede comprobar en el texto citado. Con la diferencia de que ésta de 1820 la oficia Juan de Dios González. En lugar de Medina, quien de "cara a los fieles" escucha despavorido su misa de réquiem como si fuese él espectro, Carpentier nos presenta el espectro de Cornejo Breille "frente al altar" y "de cara a los fieles".

A manera de conclusión diremos que El reino de este mundo, según sugiere Seymour Menton, es la novela que da inicio a la nueva histórica hispanoamericana; no es solamente evocación de un pasado sino un pastiche de textos históricos que Carpentier con dedicación consulta y reelabora textualmente. El pastiche, que es una de las formas expresivas de la nueva novela histórica, resulta una herramienta fundamental utilizada por el autor para la reconstrucción de la historia en esta novela. Esta obra es un mosaico en el cual podemos encontrar valiosos datos mitológicos, religiosos, etnológicos y por supuesto históricos. El reino de este mundo nos da una visión literaria de las luchas independentistas y de los primeros años de Haití como nación soberana con el rigor documental e informativo característico de las novelas de Carpentier.

\section{EL SIGLO DE LAS LUCES (1962)}

El interés de Carpentier por la historia y en particular por la época de la Revolución Francesa y su repercusión en el Caribe se manifiesta de 
manera evidente en dos novelas: El reino de este mundo, anteriormente estudiada y El siglo de las luces. La repercusión de la Revolución Francesa en el Caribe es, de por sí, un hecho extraordinario. En cada isla las ideas repercuten de manera específica. En Cuba por ejemplo, aumenta el antagonismo entre criollos y españoles; en otras como en Haití, se trata de una revolución anticolonialista seguida por la liberación de los esclavos. A la caída del poder napoleónico, España recupera en parte su poder en América; en Haití, en cambio, el poder francés desaparece. De la observación crítica de la repercusión de la Revolución Francesa en el Caribe y los acontecimientos que desencadena nacieron El reino de este mundo y El siglo de las luces.

El siglo de las luces fue publicada primeramente traducida al francés en 1962 bajo el título Le siècle des lumiéres. La novela fue acogida con entusiasmo por la crítica francesa. El crítico literario de Arts dijo sobre la novela: "Su obra ilustra un arte cuyo secreto hemos perdido de este lado del Atlántico....He aquí una novela como ¡desgraciadamente! - ya no sabemos escribirlas en Francia”. En L'Express Maurice Nadeau escribía: "Alejo Carpentier no se molesta en fijar los límites de la literatura. La hace gritar, aullar, hablar, en todos los modos y todos los registros...Ojalá tuviésemos las manos lo suficientemente anchas para recibir semejante regalo..." Y Jean Blazot, el prologuista de la edición francesa, comentaba en Le Figaro Littéraire: "El poeta sitúa y 
trasciende, en interpretaciones personales, elementos que le vienen de muchas fuentes distintas" (Citas tomadas de la contraportada de la segunda edición de El siglo de las luces, México: Compañía General de Ediciones, 1965). Pocos meses después fue publicada por primera vez en castellano, en México. Al año siguiente, fue publicada en Cuba, cuando ya la novela había sido todo un éxito en el extranjero.

El siglo de las luces como El reino de este mundo son novelas apoyadas en un intenso trabajo de investigación y documentación historiográfica. Son numerosos los trabajos de crítica literaria que insisten en el aspecto histórico de la novela. El crítico Hans-Otto Dill en su trabajo "El siglo de las luces, de Alejo Carpentier: primerísima auténtica novela histórica latinoamericana" considera que "Carpentier se destaca por su fidelidad histórica nunca antes lograda por escritor criollo alguno" (213). El propio autor en varias entrevistas ha apoyado estas interpretaciones al ofrecer antecedentes sobre el proceso de escritura y las fuentes históricos documentales en que se apoyó para escribir El siglo de las luces.

El origen de la novela, al igual que El reino de este mundo, fue un viaje que realizara el autor. Al respecto dice Carpentier:

Un viaje al golfo de la Santa Fe, en la costa de Venezuela, ampliamente descrito en el capítulo veintiséis. El lugar me fascinó, pues es uno de los más bellos y singulares de la 
costa americana [...] El otro punto de arrancada de la novela fue una escala forzada en Guadalupe, durante un viaje de Venezuela a París. (Chao 93)

Allí Carpentier conoció a Mario Petroluzzi quien le habló por primera vez sobre Victor Hugues. "Todas las noches me hablaba de Víctor Hugues, ese personaje hipostático de Robespierre metido en América" (Chao 93). Cuando el autor pudo continuar su viaje para Francia ya estaba interesado en el personaje principal de su novela El siglo de las luces. En Francia inició una investigación sobre Víctor Hugues de la cual pudo darse cuenta que el único que había escrito algo sobre Hugues era un historiador francés llamado Pierre Vitoux, quien había elaborado una biografía breve del personaje aún sin publicar. Según Carpentier: "Pierre Vitoux, con esa generosidad que tienen los intelectuales europeos para sus colegas, me puso en contacto con su archivo, me enseñó todo lo que tenía" (Chao 95). Carpentier pudo obtener una valiosa documentación histórica que utilizaría en su novela.

El autor de El siglo de las luces supo entonces que Víctor Hugues era marsellés que embarcó para América en calidad de grumete, realizando varios viajes al mar Caribe hasta dejar las navegaciones para abrir en Port au Prince un almacén de mercancías diversas. Su entrada a la historia data de la noche en que aquel establecimiento fue incendiado 
cuando la revolución hatiana. De acuerdo con las palabras del propio Carpentier:

A partir de ese momento podemos seguir su trayectoria paso a paso, tal como se narra en mi libro. Los capítulos consagrados a la reconquista de Guadalupe se guían por un esquema cronológico preciso. Cuanto - se dice acerca de su guerra librada a los Estados Unidos - la que Ilamaron los yanquis de entonces Guerra de Brigantes -, así como a la Ilamada acción de los corsarios [...] está basado en documentos reunidos en Guadalupe y en la biblioteca de Barbados, así como en cortas pero instructivas referencias halladas en obras de autores latinoamericanos que, de paso, mencionaron a Víctor Hugues. (Chao 95-96)

De la documentación reunida sobre Víctor Hugues, Carpentier pudo comprobar que no existían datos sobre donde había pasado los primeros años de su vida, y se tenía informaciones contradictorias tanto en cuanto a la fecha de su muerte como al lugar de su nacimiento. La documentación obtenida por el autor propició la creación de una de las mejores novelas de Carpentier: El siglo de las luces. 
Muchos autores han escrito acerca del carácter histórico de esta novela y el propio Carpentier, al final del relato, añade a manera de epílogo un texto titulado "Acerca de la historicidad de Víctor Hugues". ${ }^{7}$ Carpentier, abundando sobre le tema, ha declarado:

...me impuse: no mencionar cosas que se desconocieran en el tiempo en que tiene lugar la acción de la novela...limitar el uso del lenguaje a vocablos igualmente conocidos y, de otra parte, la veracidad de los hechos me obligaba a un minucioso acopio de documentación y a un rigor de historiador en la narración. (Leante 69)

No hay duda que el autor de El siglo de las luces tuvo que realizar una formidable tarea de indagación no sólo de la historia, sino también de la filosofía, la música, las artes plásticas, la literatura e incluso el lenguaje de la época.

El período histórico tratado en la novela es el de los últimos años del siglo XVIII y los iniciales del XIX. Esta novela de Carpentier recoge las distintas fases históricas por la que atravesó Francia durante estos años, (Monarquía absoluta, Convención Nacional, Directorio, Consulado) como las de sus posesiones en el Caribe. También narra otros sucesos históricos: la práctica de corzo en el Caribe; el Pacto de Basilea, en 1795, que restableció la paz entre Francia y España; la Declaración de Guerra a Francia por parte de los Estados Unidos en 1798; la ascensión al poder de 
Napoleón Bonaparte; el apresamiento de la familia real española y el consiguiente levantamiento popular de Madrid, el dos de mayo de 1808 . El siglo de las luces describe también un cambio radical: el de la sociedad aristocrática feudal francesa en burguesía capitalista.

No es Víctor Hugues el único personaje histórico de El siglo de las luces. Aparece además Robespierre. Deportados en Cayena encontramos a Collot d'Herbois, el "fusilador de Lyon" y Biallud - Varennes, "expresidente de los Jacobinos"8 Estos personajes de la historia intercalados con otros creados por la imaginación de Carpentier ayudan a crear en la novela una verdadera representación de la época. Aunque " el objetivo de Carpentier, también en este caso, no es tanto la reconstrucción de un período histórico como la reflexión profunda acerca del mismo, no se limita a hacer historiografía, quiere hacer filosofía de la historia" (Velayos Zurdos 50). Son varios los críticos que han señalado el carácter filosófico de esta novela, así como la carga de simbolismo que ella encierra. ${ }^{9}$ El no limitarse Carpentier, en El siglo de las la luces, a hacer historiografía y permitir que el texto también sea una reflexión sobre un periodo histórico y también una filosofía de la historia, está en concordancia con el planteamiento de Hayden White en Metahistory, donde White señala, como se explica en el primer capítulo de este trabajo, que no puede haber una historia propiamente dicha, que no sea a la vez una filosofía de la historia, y que los posibles "modos" de la 
historiografía son al mismo tiempo los posibles "modos" de la filosofía de la historia. Este carácter reflexivo, al aproximarse a la historia, no es ajeno a la nueva novela histórica o nuevo historicismo que han postulado críticos como Menton y Aínsa.

El título mismo de la novela, en su versión original en castellano, El siglo de las luces o su versión en francés Le siècle des lumiéres, da la impresión de ser el de un trabajo de filosofía y no el de una novela. No cabe duda que el título es irónico, ambivalente y contradictorio. ${ }^{10}$ Desde la publicación misma de la novela, éste ha sido tema de análisis. Carlos Santander considera que "el título El siglo de las luces no encabeza un tratado, sino una novela, y el equívoco posible tiene lugar porque se lo ha querido. Es una "picardía" del autor [...] una ironía,..." (500) Santander fundamenta su opinión de que el título es una ironía en las palabras del propio Carpentier cuando éste dice:

Yo tengo por costumbre - aunque no siempre- dar a mis libros unos títulos que tienen y no tienen que ver con el contenido. Por ejemplo, En el reino de este mundo se titula así porque es una inversión del reino de los cielos de los teólogos. Cuando yo publiqué El siglo de las luces mis editores se llevaron las manos a la cabeza y me dijeron: "Pero esto parece un ensayo sobre el siglo dieciocho, esto no parece una novela". Si, señor el libro se llama así por que el 
Siglo de las Luces, que se ha dado como el ejemplo de la cordura, del pensamiento filosófico, de la paz y de la calma, y todo lo que usted quiera, es uno de los siglos más sangrientos - economía basada en la esclavitud, represiones, castigos, hechicerías, matanzas de protestantes, etcéteraque se ha visto en la Historia. Por lo tanto hay un juego de palabras en el título." (Arias 38-39)

La intención de Carpentier entonces es la de establecer contrastes entre las luces y la oscuridad, entre lo transitorio y lo permanente, entre lo unitario y las pluralidades. El título, que al parecer es una referencia histórica, encierra una ironía que alude a una contradicción: todo lo que queda después de la acción y lucha revolucionaria es una realidad degradante.

Sobre el título, Claude Dumas opina: "El mismo título elegido por el autor, parece a simple vista, anunciar una disertación sobre el siglo de los filósofos, lo que no cuadra manifiestamente con el contenido global de la novela" (327). El título de la obra según se deduce del artículo de Dumas cobra un matiz de sarcasmo que orienta toda la obra en el sentido de una crítica de la época y de su acontecimiento trascendental, la Revolución Francesa. Por su parte Linda Regazzoni encuentra una 
explicación al título en la complejidad y contradicciones propias del universo de la novela cuando nos dice:

El libro lleva un título irónico que acaso, alude, al mismo tiempo, al florecimiento de las artes en un universo agitado por las revoluciones y a los "iluminados" que, paradójicamente, proliferan en ese mismo mundo, donde se cultivan las artes esotéricas y se rinde al mismo tiempo culto a la razón. (109)

El título, como la novela en sí, es una ilustración alegórica de sus ejes de significación, lo que propicia las muchas interpretaciones que se han hecho sobre esta novela en particular de Carpentier.

Entre las muchas lecturas que permite El siglo de las luces está la del teatro como metáfora. El principio de la novela es como en el teatro, se abre el telón, aparecen tres adolescentes reunidos a la muerte de su padre. Es una época de grandes lluvias y cataclismos amenazadores. Los huérfanos quedan sin problemas económicos, ávidos de libertad e independencia y deseosos de romper el orden establecido por la autoridad del padre recién fallecido. Una pintura de fondo que servirá de leitmotiv a lo largo de la novela, atraerá la atención de dos de los adolescentes: 
una gran tela venida de Nápoles, de autor desconocido que contrariando todas las leyes de la plástica, era la apocalíptica inmovilización de una catástrofe. Explosión de una catedral, se titulaba aquella visión de una columnata esparciéndose en el aire a pedazos - demorando un poco en perder la alineación, en flotar para caer mejor - antes de arrojar sus toneladas de piedra sobre gentes despavoridas. ${ }^{11}$ (Carpentier, El siglo de las luces 16)

Todos se refugian en las fantasías que leen en los libros; toda la casa se convierte en un gran escenario donde cada cual deja volar su imaginación para que tomen vida sus personajes históricos y literarios. La Historia se convierte en simulacro y sus personajes en actores. Al mismo nivel que lo literario, la Historia se torna materia de fantasía.

En este juego de la fantasía y la imaginación irrumpe Víctor Hugues, a través de quien la Historia cesa de ser fantasía y se trasforma en juego activo. Víctor es quien abre el arcón de los antepasados de los adolescentes y los invita a que se prueben los trajes; ellos entonces toman la identidad de personajes históricos o novelescos, y cada cual representa su papel. En el juego teatral, los adolescentes empiezan a reproducir revoluciones y con pelotas derriban prelados de la iglesia, capitanes de ejércitos, y figuras de la nobleza. La revolución va 
asumiendo la condición de un proyecto quijotesco. Influidos por sus lecturas los tres adolescentes, Carlos, Sofía y Esteban eliminan los límites entre la realidad y la ficción.

En El siglo de las luces la alegoría del teatro es muy frecuente y sirve para ilustrar la naturaleza dramática y pesimista de la obra. Una visión trágica del hombre es presentada como su condición natural. La naturaleza se nos presenta como cruel y maravillosa a la vez: "Sofía, observando la multitud de esas criaturas efímeras, se asombraba ante la continua destrucción de lo creado..." (El siglo 67) El hombre es parte de un mundo cruel y destructivo, y para sobrevivir el ser humano actúa su papel en el gran espectáculo del "Gran Teatro de la Universal Devoración, donde todos eran comidos por todos" (El siglo 153). Para Psiche Hughes, el aspecto teatral dentro de la novela es consecuente con el barroquismo literario de Carpentier:

Just as in the baroque vision of life, " all the world is a stage", for Carpentier, performances, not only invest every event with ceremonial quality, giving it transcendental meaning, but also they accentuate the concept of men playing a role in the ever repeating drama of humanity. (132) 
Un drama, para continuar la metáfora de Hugues, que en el caso de la Revolución Francesa, pertenece al Teatro del Absurdo, como amargamente concluye Esteban.

El teatro como metáfora en la novela también se sustenta en los dos principales personajes latinoamericanos de la novela: Esteban y Sofía. Los cuales, en parte, son espectadores, del gran espectáculo que ése estaba desarrollando en Europa: Ia revolución en Francia. Cuando Esteban llega a París tiene la impresión "de haber caído en una enorme feria, cuyos personajes y adornos hubiesen sido ideados por un gran intendente de espectáculos" (El siglo 79) A través de la novela Esteban y Sofía, a pesar de su deseo de trabajar por la revolución, de ser útil, son confinados a permanecer, como en el teatro, detrás de la escena. Al final de la novela, en Madrid, cuando estos dos personajes entran en acción, sus papeles son simplemente los de caminantes anónimos dentro de la multitud.

La guillotina, protagonista de la Revolución Francesa, da la impresión por su figura, naturaleza y función de una vívida imagen teatral. La guillotina aparece, desde el prólogo de El siglo de las luces, primero en una imagen indefinida: "Esta noche he visto alzarse la Máquina nuevamente. Era, en la proa como una puerta abierta sobre el 
vasto cielo..." (El siglo 7) Unas líneas después, en el mismo prólogo, "la Puerta sin batiente" aparece como una premonición:

Ahí estaba la armazón, desnuda y escueta, nuevamente plantada sobre el sueño de los hombres, como una presencia - una advertencia - que nos concernía a todos por igual. [...] Ya no la acompañaban, pendones, tambores ni turbas; no conocía la emoción, ni la cólera, ni el llanto, ni la ebriedad de quienes, allá, la rodeaban de un coro de tragedia antigua. (El siglo 7)

La imagen de la multitud alrededor de la guillotina nos evocan las escenas que hemos visualizado a través de los libros, el cine y las ilustraciones sobre la Revolución Francesa.

La guillotina reaparece en la ciudad costeña San Juan de la Luz; ciudad a donde Esteban había sido asignado por los revolucionarios franceses para traducir literatura revolucionaria del francés al castellano, con la intención de promover en España las nuevas ideas de la revolución. A medida que pasaban los días alejado de París, Esteban se llenaba de confusiones por no entender las constantes mutaciones y contradicciones de la política. Por la ventana de la habitación donde el joven realizaba su trabajo de traductor se divisaba que: 
en la antigua Plaza Luis XVI, ahora Plaza de la Libertad, se alzaba la guillotina. Lejos de su ambiente mayor, lejos de la Plaza salpicada por la sangre de un monarca, donde había actuado en Tragedia Trascendental, aquella máquina Ilovida ni siquiera terrible, sino fea; ni siquiera fatídica, sino triste y viscosa- cobraba, al actuar, el lamentable aspecto de los teatros donde unos cómicos de la lengua, en funciones provincianas, tratan de remendar el estilo de los grandes actores de la capital. (El siglo 93)

Las ejecuciones ya no llamaban la atención del público. Ante el espectáculo de una ejecución se detenían algunos pescadores o transeúntes de miradas enigmáticas, quienes continuaban su camino sin apurar el paso.

Esteban después acompaña a Víctor Hugues en su viaje a la isla de Guadalupe en el Caribe. A bordo de la embarcación iba la guillotina y su plataforma sirvió de escenario cuando la tripulación capturó a una embarcación enemiga en donde viajaba una compañía de ópera. Un espectáculo se improvisó en la cubierta moviendo la guillotina a un lado para usar su plataforma como escenario. Víctor Hugues mostrando el Decreto del 16 Pluvioso, que proclamaba la abolición de la esclavitud, se acercó a la guillotina e hizo volar la funda que la cubría. Apareció el 
brillo de su cuchilla a luz del sol por primera vez. Hugues, luciendo todos, los distintivos de la autoridad, con un gesto teatral apoyó su mano derecha en la máquina. La primera guillotina llegaba a América.

El estreno de la guillotina en la isla de Guadalupe fue un gran espectáculo teatral. Era el acontecimiento que todos esperaban. La población, usando ropas con los colores de la revolución, se amontonaba para mirar: "Nunca pudo verse una multitud más alegre y bulliciosa con aquellos tintes de añil y fresa que parecían tremolar al mismo ritmo de las banderas en la mañana límpida y soleada" (El siglo 129). Aquellas personas que nunca habían visto teatro estaban descubriendo ahora el significado del drama. "Aquí no se tenía nada semejante; nunca habíase visto un escenario abierto a todos, y por lo mismo descubrían las gentes, en aquel momento la esencia de la Tragedia" (El siglo 130). Y como en la tradición trágica, el pueblo participaba asumiendo el papel del coro, cantando estrofas en aquel espectáculo de la Plaza de la Victoria.

Los personajes de El siglo de las luces tienen conciencia de ser personajes, pero no de la novela de Carpentier, sino de la que ellos mismos inventan. Ellos, en su fantasía, recrean revoluciones y discuten con pasión como hacerlas. Una vez que han decidido qué papel van a representar, abandonan el escenario de ensayo, su casa, para actuar y poner en práctica sus ideales en los escenarios reales. 
A partir de entonces los personajes de esta novela, como casi todos los personajes de Carpentier serán "símbolos andantes de ideas y actitudes" (Harss 75). Una vez confrontados los personajes con la revolución, cada uno desarrollará su papel de manera diferente, pero siempre estarán controlados por la voz narradora. En El siglo de las luces: "la vida está echada en contra de las vidas individuales, arrasadas por los acontecimientos, sacrificadas ciegamente a la marcha del progreso histórico" (Harss 64). En el texto de Carpentier, como en la antigua tragedia, existe una especie de fatalismo, cada personaje tiene ya un papel predestinado del cual no puede escapar.

Las descripciones de los personajes en El siglo de las luces son insignificantes, solo ocupa unas breves líneas a partir de la segunda página, mientras la descripción del ambiente es detallada. A través de este recurso, el autor logra que el lector fije más su atención en las descripciones del ambiente y en el acontecer histórico. Reinaldo Arenas señalaría en una entrevista:

[en] las novelas de Carpentier llega un momento en que los personajes están tan connotados por la historia [...] que no se pueden mover: cada vez que se mueven hay que connotar el paso que dan, la época de la alfombra que pisan, el paño con que se cubren el cuerpo, el mueble donde finalmente se 
sientan; es decir que agotar el contexto tan fielmente que Ilega un momento en que por ejemplo el personaje de Sofía, de El siglo de las luces, casi no puede moverse con toda la utilería que Carpentier la provee." (Santi 25)

Los personajes de El siglo de las luces son esquemáticos y sin complejidad psicológica. Se encuentran atrapados por la fidelidad al discurso historiográfico tradicional como a una serie de contextos. Ellos experimentan cierta evolución con respecto a su actitud ante la Historia, aunque esa actitud queda siempre confinada al ámbito de la fantasía y la ilusión, como en El reino de este mundo.

La evolución de los personajes es comparable en El siglo de las luces con la imagen de la espiral. Esteban, el personaje, que persigue una utopía a un nivel intelectual, pero que es incapaz de llevarla a la práctica, parece sentirse pleno en los momentos en que se detiene en la contemplación. El personaje experimenta una epifanía al mirar el diseño de la concha de un caracol:

Esteban, desnudo, sólo en el mundo [...] abismábase en la contemplación de un caracol -de uno solo - erguido como monumento que le tapara el horizonte [...] El caracol era el mediador entre lo evanescente, lo escurrido, la fluidez sin ley ni medida, y la tierra de las cristalizaciones, estructuras y 
alternancias [...] De la Mar sometida a ciclos lunares [...] surgían estos sorprendentes carapachos, símbolos en cifras y proporciones [...] Contemplando un caracol -uno solopensaba Esteban en la presencia de la Espiral durante milenios. (El siglo 154)

La descripción que se hace el narrador del caracol en la novela eleva a éste a la categoría de objeto artístico. Además, el diseño del caracol es significativo, por lo que tiene de recurrencia. La circularidad recurrente es afín al concepto de la historia de Carpentier.

El concepto de la circularidad de la historia en las novelas de Carpentier se encuentra tanto en El reino de este mundo como El siglo de las luces. En la primera, encontramos ciclos históricos idénticos que se mueven por las fuerzas naturales. En El siglo de las luces no encontramos ciclos históricos idénticos, ya que la historia tiene en este libro un movimiento en forma de espiral que no está determinada por la naturaleza ni ninguna fuerza cósmica sino por el hombre. Para Carpentier, nos dice el crítico Luis Harss:

la esencia de la historia consiste en que se repite. Así, sucede, por ejemplo, que las revoluciones se institucionalizan para dar cauce, finalmente, completando el ciclo, a nuevas revoluciones. El progreso es relativo, un 
concepto cronológico que puede medirse sólo dentro de un contexto histórico dado, en un lapso más o menos finito. (Harss 65)

En El siglo de las luces este movimiento en espiral de la historia lo vemos de esta manera: una primera fase llena de idealismo e ilusión, que dará a lugar a la burocracia para llegar a la corrupción, a la violencia y finalmente, a generar el desencanto y la resignación.

A manera de conclusión diremos que En El siglo de las luces se pone de manifiesto el interés que Carpentier siempre ha tenido por la historia. Tanto en El reino de este mundo como en El siglo de las luces se hace evidente el interés particular del autor por los sucesos de la Revolución Francesa y su repercusión en el Caribe. Ambas novelas están apoyadas en un fuerte trabajo de investigación y documentación historiográfica, y fueron inspiradas a partir de los viajes que Carpentier realizara por el Caribe.

Carpentier rescata en El siglo de las luces al personaje histórico de Víctor Hugues olvidado por el discurso historiográfico tradicional. En esta obra se recrean sucesos históricos de los últimos años del siglo XVIII y los iniciales del XIX, respetando tanto el lenguaje de la época como los contextos culturales, económicos y políticos entre otros. El siglo de las luces es una novela que permite múltiples lecturas. La multiplicidad de 
perspectiva es una de las características de la nueva novela histórica hispanoamericana. El teatro como metáfora de la Historia o la vida como simulacro es una de sus lecturas, donde los personajes son símbolos de las ideas y actitudes que son arrasadas por las fuerzas de los acontecimientos y del "progreso histórico". Los personajes de esta novela se encuentran atrapados tanto por la documentación historiográfica realizada por el autor, la cual sirve de apoyo a la novela, como por la recreación de la época lograda por el autor como escenario de sus personajes.

Varias son las lecturas que ha tenido El siglo de las luces, dentro de las cuales está la de la novela del desencanto revolucionario. ${ }^{12}$ Hay críticos que han hecho otra lectura de esta novela a partir de una analogía de la Revolución Francesa con la Revolución Cubana de1959. ${ }^{13}$ A partir de esa lectura en El siglo de las luces existe una "presentización" y desmitificación de la historia. ${ }^{14}$

En El siglo de las luces Carpentier hace una relectura de la historia y si se quiere también una reescritura paródica de la misma, pero Carpentier no se aleja del discurso historiográfico tradicional. Tanto El reino de este mundo como El siglo de las luces forman parte de lo que Aínsa llama "el conjunto de novelas históricas fidedignas de Carpentier" ("La reescritura de la historia" 14). Ambas novelas, como pudimos 
comprobar en nuestro trabajo, se apoyan en el registro oficial historiográfico. No hay realmente una impugnación de las versiones oficiales de la historia como sí encontramos en novelas posteriores de otros autores hispanoamericanos y del propio Carpentier en su última novela El arpa y la sombra. No hay en El reino de este mundo ni en EI siglo de las luces la reelectura "pesadillesca", acrónica de la historia mediante la escritura carnavalizada y de humor agudo que caracteriza a la novela histórica en su corriente más actual. 


\section{NOTAS}

' Sobre la calificación de esta obra como novela histórica dice Federico Acevedo en su "Introducción" a El reino de este mundo:

Si bien es cierto que $E l$ reino de este mundo guarda gran fidelidad a los principales datos históricos, sucesos acontecidos y personajes recreados, no es menos cierto que la calificación de novela histórica no agota, por sí sola, la cuestión del género literario. Todavía es necesario añadir a ese calificativo, empleado en una obra que el autor llamó "relato", que cada una de las partes aparece dominada por el tipo de conciencia y escritura imperante respectivamente en una de las principales manifestaciones del género épico: la epopeya y la novela. (xliii)

${ }^{2}$ Son cinco períodos o etapas de la historia de Haití las que aparecen en la novela, las cuales están relacionadas con los principales personajes históricos que aparecen en la narración. Estos períodos son: el de Mackandal (1751-1758); el de Bouckaman (1791), el de Paulina Bonaparte, la derrota de los franceses y la independencia de Haití (1802 1804); el de Henri Christophe (1807 - 1820); y el de los Mulatos Republicanos (1825 1831). El personaje de Ti Noel enlaza los diferentes períodos y permite la continuidad narrativa.

${ }^{3}$ Los sucesos históricos narrados en esta novela de Carpentier aunque reales se encuentran organizados en función de exigencias narrativas y aparecen según las necesidades del universo de ficción creado por el autor.

${ }^{4}$ El reino de este mundo, si se coteja con los hechos históricos que narra, podemos decir que cubre un período de unos ochenta años (1775-1830). Es el tiempo que media entre la conspiración de Mackandal y el establecimiento del gobierno republicano y la imposición del trabajo agrícola obligatorio.

${ }^{5}$ Mario Vargas Llosa acertadamente dice que la rebelión de Mackandal narrada en El reino de este mundo (capítulo V, "De Profundis") es "Uno de los episodios más deslumbrantes de la novela" (35). El autor agrega que en este capítulo con la muerte de Mackandal el narrador consigue "una admirable muda en la realidad ficticia: volver legendario, mítico, casi sobrenatural, un hecho muy concreto y circunscrito de la historia haitiana" (35).

${ }^{6}$ El autor impregna de milagro y maravilla la realidad histórica convirtiéndola en fantástica pero manteniéndola levemente sujeta a la vida objetiva, en la que las leyendas y mitos coexisten y con frecuencia desvanecen la experiencia histórica.

${ }^{7}$ Andrés Amorós y Anderson Imbert han calificado a El siglo de las luces como novela histórica. Ver Introducción a la novela hispanoamericana actual de Amorós e Historia de la literatura hispanoamericana de Imbert. Hans-Otto Dill considera que: "El siglo de las luces es más que la precursora: El reino de este mundo es una de las primeras Nuevas Novelas y la primerísima auténtica novela histórica latinoamericana." (205)

${ }^{8}$ Otros personajes históricos son citados, como por ejemplo: Danton, Brissot, Marat, Saint - Just, Carrier, los agentes Leannet y Burnet, le general Desfourneaux, Antonio Fuët (marino de Narbona, protagonista de lo que los norteamericanos Ilamaron Guerra de Brigantes) y Toussaint - Louverture. 
${ }^{9}$ Sobre el carácter filosófico de El siglo de las luces consultar el artículo de Claude Dumas: "El siglo de las luces de Alejo Carpentier, novela filosófica; Roberto González Echevarria: "Historia y alegoría en la narrativa de Alejo Carpentier, así como La narrativa de Alejo Carpentier: el concepto del tiempo.

${ }^{10}$ En inglés la novela se publicó con el título: Explosion in a Cathedral.

"Todas las citas de la obra usadas por mí en este trabajo corresponden a la siguiente edición: Alejo Carpentier. El siglo de las luces. Argentina: Editorial Quetzal, 1978.

${ }^{12}$ Existen varios trabajos que sustentan esta lectura. Puede consultarse: Carlos Santander. "Historicidad y alegoría en El Siglo de las luces de Alejo Carpentier"; Alicia Puleo "El siglo de las luces: dialéctica de la razón y la pasión"; Sinesio Fernández. "El mito de Sísifo en El siglo de las luces"; Ana Serra. "La revolución como simulacro en El reino de este mundo y El siglo de las luces de Alejo Carpentier"; E. Méndez y Soto. "La trayectoria revolucionaria de El siglo de las luces"; Emir Rodríguez Monegal "Trayectoria de Alejo Carpentier". Cuando se le preguntó a Carpentier sobre la tesis de Emir Rodríguez Monegal de que El siglo de las luces es la novela del desencanto revolucionario, éste respondió:

Los hombres pueden flaquear, caer, sucumbir, traicionar incluso lo que amaron un día. Pero las ideas no caen al vacío. La Revolución Francesa fue aplastada, desintegrada, desvirtuada, desembocando en el reinado de una burguesía feroz. Y sin embargo, la idea revolucionaria - novísima en 1789- siguió imperturbablemente su camino a través de todo el siglo pasado, hasta desembocar en las revoluciones del presente. (Chao 98)

${ }^{13}$ La publicación de El siglo de las luces, primera novela publicada por el autor después del triunfo de la Revolución Cubana, provocó polémicas acerca de las lecturas sobre el desengaño revolucionario y sobre la asociación de la novela con la Revolución Cubana. Seymour Menton en La narrativa de la revolución cubana dice que la obra: "plantea dudas sobre el idealismo revolucionario, que podrían ser aplicadas a la Revolución Cubana, habiendo sido ésa la situación del autor o no". (52-53) La actitud de Carpentier ante la situación política cubana también fue motivo de polémica. Muchos vieron que ni su vida ni sus obras literarias se correspondían con sus llamamientos al compromiso político. Roberto González Echevarria resume parte de esta polémica en "Historia y alegoría en la narrativa de Carpentier".

${ }^{14}$ Hans- Otto Dill considera que: "El mundo de esta novela nos parece a nosotros, los lectores de hoy, a la vez extraño y nuestro, muerto y vivo, impresión que es el resultado novelístico del concepto carpenteriano de la Historia" (205). 


\section{Cuarto capítulo: La nueva novela histórica de Abel Posse}

\section{DAIMÓN (1978)}

\section{EL AGUIRRE HISTÓRICO}

Lope de Aguirre forma parte del grupo de los "desheredados" de la Conquista. Su rebelión fue un acontecimiento singular por su radicalismo. No así los motivos que impulsaron a los insurgentes. Estos motivos, por el contrario, representan el pensamiento de la mayoría de los conquistadores después de 1542. A partir de ese año, se instauraron las Leyes Nuevas que limitaron la explotación de los indígenas por parte de los españoles. Las rebeliones de Gonzalo Pizarro, Sebastián de Castilla y Francisco Hernández Girón ya habían sido expresiones de protesta de los encomenderos contra las Leyes que pretendían quitarles los privilegios que ellos pensaron haber conseguido legalmente, arriesgando sus vidas y su capital.

Lope de Aguirre como parte de los Ilamados "desheredados" de la conquista no tiene ni encomienda ni repartimiento de indios, pero piensa que la corona está obligada a otorgárselo por los servicios prestados. Sabiendo que la expedición que baja por el Amazonas para buscar la tierra de los Omaguas, Ilamada también de El Dorado, sólo es un pretexto para eliminar solicitantes incómodos del territorio colonizado, convierte la entrada en una sublevación, eliminando a su vez a todos los que no 
comparten su objetivo de regresar al Perú con el fin de tomar el lugar de los poderosos y de vivir bajo un monarca de su elección. La separación de España se testifica ante el escribano. Sin embargo, el plan fracasa, porque llegados a tierra colonizada, los compañeros de Aguirre traicionan el objetivo del grupo, pasándose al bando de la corona, como ya había ocurrido en las rebeliones anteriores. Antes de ser descuartizado, Aguirre escribe, con inaudita insolencia, una carta a Felipe II exponiendo los motivos de su rebelión y mata a su hija para que no sea violada por los adeptos al Rey. Hasta aquí el acontecimiento histórico tal como resulta del análisis de las fuentes tradicionales.'

\section{EI AGUIRRE LITERARIO}

A lo largo del siglo XX, la historia del conquistador español Lope de Aguirre ha inspirado varias obras de ficción y películas. ${ }^{2}$ Lope de Aguirre era conocido sobre todo en Venezuela y en las vascongadas (el país vasco), pero también en el resto de España, en Colombia y en el Perú. A partir de la exhibición de la película Aguirre, la cólera de Dios (1975) de Werner Herzog y El Dorado (1998) de Carlos Saura, el personaje de Lope de Aguirre se vuelve célebre en otras partes del mundo. A partir de entonces se ha hecho varias reescrituras sobre la vida del conquistador que utilizan el material que les entrega la historiografía tradicional. 


\section{EI AGUIRRE DE POSSE: DAIMÓN}

La historia ha sido una de las pasiones de Abel Posse y sobre ella regresa una y otra vez en sus libros. La que concierne al choque de dos culturas contrapuestas, como la europea y la indígena en América, se ve reflejada en una trilogía que comienza con Daimón (1978) y se prolonga en Los perros del paraíso (1983) y El largo atardecer del caminante (1992).

Para Posse, América Latina es un continente eternamente adolescente, "una especie de monstruo histórico adorable, pero que todavía no alcanzó esa transformación de su cultura en una forma de civilización adorable" (lacoviello 4). En la obra de Posse hay un motivo constante: la ruptura entre la sociedad judeocristiana de la culpa y la nostalgia por los dioses y el paganismo del hombre americano primigenio. En su obra hay un revisionismo de la cultura impuesta por la conquista española en América.

En su primera etapa de escritor leyó mucho a Faulkner, Dos Passos, Thomas Wolfe y Melville. Pero es Faulkner a quien considera como la influencia más destacada en él y en todos los grandes escritores de América Latina. ${ }^{3}$ Sobre los escritores latinoamericanos dice que: "Carpentier es un gran maestro, pero mi ídolo es Lezama Lima. Me parece que es el que llegó más lejos como locura, como lenguaje, como uso de la cultura de una manera absolutamente libre. Él y Borges, en este punto, 
son casi el paroxismo" (García Pinto 497). En su formación literaria influyeron los escritores rusos Dostoievski, Chejov, Pushkin y los grandes disidentes del discurso oficial francés como Rimbaud, Proust, Céline y Jean Genet.

Su primera novela Los Bogavantes (1968), se presentó al premio Planeta pero por la censura no pudo ser publicada en España hasta 1975. La novela es una reflexión crítica sobre la historia contemporánea, fundamentalmente sobre la Europa occidental. En La boca de tigre (1971), tenemos otra vez a Europa, ahora la del Este, como objeto de atención del novelista. Otras novelas como Los demonios ocultos (1987) y El viajero de Agartha (1989) están dedicadas al fenómeno del nazismo. Sus novelas que se acercan a la historia de América permiten al autor avanzar, mediante particulares procedimientos de diálogo y de radicalización hipertextual, hasta el momento presente, conectando a Europa con América. Su anunciada novela Los heraldos negros, tendrá como tema la acción de los jesuitas en el Paraguay.

Sus novelas Daimón (1978), Los perros del paraíso (1983) y El largo atardecer del caminante (1992) conforman una trilogía en la que el autor ingresa en la novela histórica de una forma muy especial. En estas novelas el escritor va más allá de la historia, introduciéndose en el ámbito de comprender nuestra época, las raíces y lo que él denomina "adolescencia eterna" de Hispanoamérica. En estas tres novelas hay un 
gran trabajo historiográfico y de investigación que ayudaron al autor a formar una visión de lo americano que no fuera solamente la consabida visión eurocéntrica. A través del trabajo investigativo, el autor alcanza, una visión estética que surge desde el lenguaje y las ideas como ocurre en Daimón donde se recrea al personaje histórico de Lope de Aguirre.

Las tres novelas de Posse que analizaremos en este trabajo Daimón, Los perros del paraíso y El largo atardecer del caminante tienen la afinidad de generarse de la biografía de tres grandes descubridores: Lope de Aguirre, Cristóbal Colón y Álvar Núñez de Cabeza de Vaca. ${ }^{4}$ Tres buscadores de quimeras, tres viajeros deslumbrados por los mitos clásicos de la Edad Media o el Renacimiento. Daimón (1978) de Abel Posse es una original sucesión de quinientos años de la historia de Hispanoamérica. ${ }^{5}$ Posse salta desde el campamento de Lope de Aguirre resucitado a la orilla del río en medio del Imperio Marañón, hacia el Este, hacia el pueblo de los hombres anfibios, y desde ahí, sucesivamente, al país de las Amazonas, a Cartagena de Indias, y luego hacia el Sur, hacia el país de los gigantes, y más al Sur, hacia los dominios guaraníes, hasta El Dorado. El texto de Posse nos llevará por Arequipa, Machu-Picchu, Lima, la selva, Manaos, y el lago Tititaca entre otros lugares. El autor salta desde el doce de mayo de 1637, fecha de la resurrección de Lope de Aguirre, hasta el quince de junio de 1719, y desde el diez de febrero de 1756 hasta el nueve de abril de 1802. La novela continúa describiendo 
acontecimientos históricos del siglo XX hasta la década de los setenta, con el fin del gobierno de Salvador Allende y la subida al poder de Augusto Pinochet acontecimientos históricos que parecen poner fin a la novela.

Esta novela de Posse, en su intento de recorrer quinientos años de la historia de América, hay mucho de lo planteado en el ensayo $L a$ expresión americana de José Lezama Lima. Lezama en su ensayo lleva a cabo, como Posse en Daimón, una especie de revisión histórica llegando al siglo XX. La visión que Lezama tiene de la historia se alimenta de visiones que no pueden ser reducidas a esquemas lógicos y racionales. Los planteamientos de La expresión americana exigen una revaloración de los planteamientos historiográficos tradicionales, de igual manera, Daimón es un texto que demanda una nueva valoración de la historiografía. Aunque debemos puntualizar que Daimón no está en concordancia con La expresión americana en la visión sociopolítica y económica sobre la cultura hispanoamericana, el texto de Posse, en este aspecto es más afín a los enfoques tradicionales que han prevalecido sobre la cultura hispanoamericana, de la cual el ensayo de Lezama se aparta. Pero Daimón, como en casi toda la obra de Posse, sí está en consonancia con La expresión americana cuando nos brindan una visón metafórica de la historia que completa la visión del discurso historiográfico tradicional. Para Posse, como para Lezama, la imagen 
participa de la historia creando ese espacio contrapunteado, metafórico, donde las entidades naturales y culturales actúan como personajes y pueden adquirir resonancias y nueva vida.

El texto de Posse es un collage con una variedad de registros temáticos que incluyen la política, la sociedad, la economía, la literatura entre otros. Posse convierte a Lope de Aguirre en un espectro inmortal a quien hace caminar por diferentes espacios y tiempos de la América Latina. Como bien plantea Juan Manuel García Ramos:

Daimón es la novela de la "fantasmalidad", el relato alucinante de un Lope de Aguirre redivivo que vuelve sobre sus pasos de conquistador y cruza por los siglos y los acontecimientos del último milenio con todas las prerrogativas de un demonio ubicuo, de un ser maldito y ajeno a la servidumbre del tiempo y del espacio que sufre los humanos. (Abel Posse 74)

En Daimón no se intenta dar explicaciones históricas de la conducta de su personaje protagonista. En el texto de Posse ni siquiera se relatan las peripecias del Aguirre histórico, puesto que la trama se inicia cuando el conquistador muerto resucita. Posse, en un enfoque novedoso del personaje y de su tiempo histórico, toma la vida de Aguirre y la reconstruye después de su trágica muerte y lo devuelve a la tierra de sus andanzas. ${ }^{6}$ 
El Lope de Aguirre que regresa a la vida es un pícaro, amoral, casi inmortal, pues sigue vivo hasta el siglo XX. En esta novela "la figura del viejo conquistador sirve para teatralizar repetidamente el texto de América, cuyos elementos historiográficos o literarios se transmutan en parodia alucinada" (Kaplan 277). En Daimón no se reconstruyen los trágicos sucesos de Omagua según nos cuenta el discurso tradicional historiográfico. El autor reconstruye a un Lope de Aguirre encabezando un ejército de ánimas vagando por la América española después del año 1561. Sus hombres despiertan afecto y cariño y nunca indignación o repulsa.

El Lope de Aguirre de Posse, al regresar después de muerto a la tierra, adquiere una omnipresencia histórica. El autor maneja al personaje con un contrapunto entre el pasado y el presente permitiéndole dos importantes recursos: el humor y el barroquismo. Lo barroco, En Daimón, como plantea Alexis Márquez Rodríguez:

abarca desde la concepción misma de la novela con la inusitada regresión de la muerte a la vida que plantea la secuencia anecdótica, hasta el instrumental estético del lenguaje, con sus metáforas y demás figuras retóricas típicamente barrocas, pasando por las estructuras del relato y muchos otros elementos de mayor o menor significado. (Abel Posse 56) 
El barroquismo En Daimón, y en general en todas las novelas de Posse, es evidente; pero este barroquismo no debe confundirse con una imitación del barroco español, ni tener en cuenta solamente el punto de vista estilístico y determinados rasgos de lenguaje.

El sentido del humor agudizado es una de las características de la nueva novela histórica hispanoamericana. El humor impregna todas las novelas de Posse y está inscrito también dentro del esquema barroco de Daimón. El humor en Posse transciende a lo satírico y lo grotesco. El humor en la novela es uno de los recursos que permiten al autor la transgresión del tiempo o lo que ya mencionamos como un contrapunto entre el pasado y el presente. Veamos un ejemplo:

Volvieron a Cuzco porque la morita debía entregar un mensaje a los traficantes de armas y renovar un juego de claves secretas. Estaban eufóricos. Aguirre abandonó el poncho y las alpargatas. En la sucursal de Sears, ella le hizo comprar una camisa deportiva con grandes flores rojas y amarillas estilo Nolde y un saco de sport norteamericano, con rayas azules y rojas. Un par de mocasines blancos, de automovilista. (268)

Este pasaje de Daimón ilustra, con el humor que caracteriza las novelas de Posse, como se logra la transgresión del tiempo a través de un contrapunteo entre el pasado y el presente. También ejemplifica lo que 
Brian MacHale denomina como "anacronismo creativo", o sea cuando un elemento cultural de la actualidad es sobreimpuesto dentro de un contexto cultural del pasado. ${ }^{7}$

La novela empieza con una sinopsis de Lope Aguirre escrita por el autor que dice:

Lope de Aguirre (1513?-1561) Denominóse el Tirano, el Traidor, el Peregrino. Antiimperialista, declaró la guerra desde la selva amazónica, rodeado de monos a Felipe II, [...] Demonista. Erotómano. Tímido pero tenaz. Rebelde. Su crueldad es proverbial. Amoral como un tigre, como una paloma. Aparentemente creyó en la voluntad del poder. [...]Siguió viviendo en el Eterno Retorno de lo Mismo, que es una espiral espacio-temporal. (8)

La desmitificación de la historia es otra de las características de la nueva novela histórica hispanoamericana presente en Daimón. El discurso narrativo de Posse en Daimón es desmitificador y contempla la historia de manera circular y pesimista. El hombre vive atrapado en una espiral continua que no le permite avanzar. Cada paso nuevo implica varios retrocesos, una suerte de castigo de Sísifo que no permite alcanzar nunca la plenitud.

La teoría del Eterno Retorno es aludida por Posse en Daimón. ${ }^{8}$ Esta novela "resume, en cierto modo, toda la narrativa del $<<$ movimiento 
centrípeto >> bajo la mirada de un Lope de Aguirre envejecido y que cada vez comprende menos lo que pasa en el territorio de su imperio" (Aínsa, Identidad cultural 304). Lope renace de su propia muerte. $Y$ este renacimiento es a la vez el hilo conductor que rige la narración. Lope de Aguirre renace para seguir siendo un muerto que peregrina y guía a su vez la narración. El personaje no cuenta nada nuevo, sino que recorre y revive los sucesos históricos pero desde un punto de vista diferente al tradicionalmente usado para narrar la historia hispanoamericana.

La relectura de la historia fundada en un historicismo crítico y la impugnación de las versiones oficiales de la historia, características de la nueva novela histórica hispanoamericana, se manifiesta de manera evidente en esta novela de Posse. En Daimón los acontecimientos son contados desde el punto de vista americano y no desde la perspectiva del conquistador, ni desde el punto de vista del pensamiento eurocéntrico que ha dominado la historiografía tradicional en el tema del descubrimiento y la conquista. Como acertadamente plantea Aínsa en Identidad cultural de Iberoamérica:

No otra cosa hace Abel Posse en su novela Daimón al convertir a Lope de Aguirre en un personaje alegórico de una identidad americana hecha de contradictoria mezcla de ambiciones territoriales, pasiones violentas y voluntad "integradora". (304) 
Posse, con ironía y un tono desaforado, convierte a Lope de Aguirre en un símbolo de múltiples significaciones.

La multiplicidad de perspectivas es también una de las características de la nueva novela hispanoamericana. Una aproximación cuidadosa a Daimón nos permite a los lectores darnos cuenta que estamos frente a un texto que se multiplica también en muchos significados. La organización de esta novela se estructura mediante las cartas del Tarot. De tal modo, la comprensión de la historia de América, según el texto de Posse, se transforma en una rama de las ciencias ocultas. Hay en Daimón una concepción del mundo (afín a la idea de Borges) como una biblioteca, un texto o una carta donde podemos encontrar todas las respuestas a los misterios del hombre. Es precisamente, mediante otro libro, en este caso las cartas del Tarot, que esta novela de Posse buscará un orden a su cosmovisión.

La idea del Tarot como texto no es nueva. Campell Tatham enfatiza la idea del Tarot como un texto y como metáfora:

Tarot, fundamentally is a text whose structure is indeterminate and whose pages (the individual cards) lend themselves to endless rearranging. [...] And no reading can be final: the spread leads me to make one story today; tomorrow, I may return to it and craft a quite different story, the change a function of circumstances [sic]. There is, 
however, nothing disturbing about this, for the truth of Tarot is that of metaphor, not fact. Tarot is, then, the epitome of the open text, quintessentially postmodern. (582-583) Numerosos estudios destacan las correspondencias entre la lectura tarótica y las ideas de Carl Jung sobre los arquetipos y el inconsciente colectivo, señalando que las cartas, en cuanto a símbolos arquetípicos de la experiencia humana, posibilitan al individuo ponerse en contacto con su parte no racional. Otros estudios hallan correspondencias entre el viaje simbólico contenido en el Tarot, y los mitos universales sobre el viaje del héroe, las tradiciones órficas y los ritos iniciáticos estudiados, por ejemplo, por Joseph Campbell y Mircea Eliade. Daimón no es la primera novela que acude al uso del Tarot como estructura organizadora de otra narrativa. Existen varios antecedentes literarios como The Castle of Crossed Destinies de Italo Calvino y la obra de T.S. Eliot The wasteland. Hay diferentes versiones de las cartas del Tarot, al parecer la que tuvo en mente el autor al escribir Daimón es el sistema de Arthur E. Waite, en su libro The Pictorial Key to the Tarot (1910). En el sistema de Waite, se echan diez cartas en un orden predeterminado, existiendo una oncena carta que inicia la lectura y que, según Waite, representa la persona o asunto de que se trata. La novela de Posse, de igual manera está dividida en diez capítulos cuyos títulos corresponden a diferentes cartas del Tarot. Y al comienzo de la novela se incluye una nota 
biográfica de Aguirre a modo de epígrafe (que sirve para producir la apertura de los significados contenidos en los signos posteriores) donde se plantean los principales rasgos del protagonista.

El primer capítulo de Daimón se titula: UN ARCANO MAYOR: LE JUGEMENT DES MORTS. EL JUICIO DE LOS MUERTOS. Lope de Aguirre y sus hombres renacen en este texto que les da vida como personajes. Comienza una nueva vida para Aguirre y sus hombres quienes abandonan el mundo de ultratumba para retomar su interrumpido peregrinaje. Mediante una escritura carnavalesca, los personajes de Daimón retornan a la vida y nos llevan al origen o "descubrimiento" cuando el texto de Posse, invirtiendo las jerarquías tradicionales del discurso historiográfico, nos plantea que: "El 12 de Octubre de 1492 fue descubierta Europa y los europeos por los animales y hombres de los reinos selváticos" (28). El capítulo nos remite al mito del Ave Fénix: el renacimiento de sus propias cenizas, para seguir muriendo y renaciendo en un Eterno Retorno.

En Daimón, el judío, Lipzia, adivino oficial de la expedición, es quien interpreta dicha carta: "Es la carta del renacimiento, del ciclo cumplido, del jubileo, Mírala Señor, éste que está parado en la tumba podría ser Lázaro" (17-18). Al declararse en rebeldía Lope de Aguirre se convierte en un opositor a las fuerzas de la cosmogonía judeocristiana, ya que se asocia su rebeldía con la del Demonio, quien, según la 
mitología judeocristiana,sería un ángel rebelde vencido por Dios: "que [Felipe II] se quede con su Dios que yo prefiero mi Demonio. Y que si después de quince siglos de tanto cristo estamos como estamos que lo invito a probar del lado del demonio, ja ver que pasa!"(23), exclama Lope de Aguirre. El conquistador es por lo tanto el demonio o "daimón" que se rebela contra el poder divino, o sea Dios, y el terrenal, entiéndase la Iglesia y el Rey.

Los capítulos iniciales de la novela de Daimón establecen el contraste entre los dos mundos enfrentados. De una lado, América, "en el implacable ciclo de leyes cósmicas que parecen recién establecidas" (11); del otro lado, "la ambición y el temor, signos inconfundibles de vitalidad europea" (36). Según el texto de Posse, los hombres de los pueblos selváticos americanos "pronto quedaron convencidos de que estos invasores estaban profundamente enemistados con el Espíritu de la Tierra. Carecían de armonía y de paz" (49). La conducta de los europeos es interpretada en la novela desde lo que puede haber sido la percepción de los nativos. Éstos ven en los hombres venidos de Europa una incapacidad para comprender el equilibrio y el orden natural de las cosas.

La voz narrativa de la novela dramatiza el conflicto de las dos concepciones del mundo presente en el texto. Sin embargo, el Lope de Aguirre que nos presenta la novela, el que regresa a los escenarios de la conquista, no es la del hombre europeo seguro de la validez de sus 
actos. Cuando Lope recuerda las masacres, los saqueos y violaciones, su óptica ya no es la del conquistador, pues ha incorporado la experiencia de los vencidos. En Daimón tiene lugar un proceso de americanización del personaje de Lope de Aguirre que va profundamente identificando al conquistador con el mundo conquistado.

Lope de Aguirre y sus hombres rebeldes van por el espacio y el tiempo de América reproduciendo frustraciones y fracasos. Entran en el siglo XVIII en Cartagena de Indias, donde descubren el poder del comercio y de las nuevas armas. Lope reafirma su rebeldía con una nueva declaración de guerra al rey de España:

Mi Imperio es doscientos veces más grande que tus Españas de hoy, aquí, en tu Cartagena todavía usurpada, rodeado de tus comerciantes, esclavos, inquisidores y alcaldes, te traigo testimonio de mi alzamiento, que es el eterno alzamiento de América. (99)

Posse se distancia de la historia oficial mediante su reescritura paródica y carnavalesca y va transformando al antiguo conquistador hasta hacerlo sentir el sentimiento de inferioridad, el abatimiento y rencor del conquistado. Lope llega a sentirse americano. ${ }^{9}$ Llega a encontrar las dunas de oro del Dorado, pero las abandonará, permitiendo que sus hombres sirvan al nuevo Inca y Señor Tupac - Amaru. Lope, por su parte, va en busca del amor, y acompañado de la niña-monja entra acompañado 
"del lenguaraz del incario que alguna vez hizo degollar" (Daimón 100) en Machu Picchu, ciudad inca que no fue descubierta hasta el siglo XX.

Posse distorsiona el discurso historiográfico tradicional mediante una escritura paródica, carnavalesca, y anacrónica al mantener vivo a Lope de Aguirre durante el siglo XIX americano y parte del XX. Lope es testigo de los movimientos de independencia en América, del nacimiento de las nuevas repúblicas, y de la toma del poder político de las burguesías nacionales. En Daimón se registra con ironía como los nuevos burgueses de las nuevas repúblicas hispanoamericanas desprecian al indígena y temen hacer el ridículo frente al europeo. En el texto de Posse, Lope se encuentra con que sus antiguos compañeros de la jornada de Omagua, con sus prostitutas transformadas en damas, se han convertido en la clase dirigente de las nuevas naciones.

La novela llega al noveno y penúltimo capítulo, el cual recoge las primeras décadas del siglo XX en Hispanoamérica y nos presenta a un Lope de Aguirre que siente su marginalidad y "la frustrante sensación de no haber sabido asumir su manifiesto destino imperial" (175). Este capítulo de Daimón se titula ARCANO XV: LE PENDU, EL COLGADO. La carta del Tarot del colgado muestra a un hombre colgado cabeza abajo en una sola pierna. La figura del Tarot, "El Colgado", puede ser vista como representativa de la condición de los vencidos quienes son convocados a una reunión en la selva de Chahapoyas: 
Aguirre sería bien visto en caso de ir. Evidentemente ya no se le tenía por ibérico, o su hispanidad quedaba ya asimilada en la desgracia. Juzgó que no era poco honor poder participar en un Congreso que reuniría todas las desdichas de los despojados. (231)

En su viaje el protagonista se cruza con negros de los ingenios azucareros, obreros de caucho amazónico, campesinos del Brasil y revolucionarios zapatistas.

Lope ya enfermo es ahora un latinoamericano más que reniega de su pasado europeo. Reafirma su identidad participando en un Congreso de indios, animales y plantas reunidos secretamente para discutir el avance europeo. El texto de Posse recurre al uso abundante del anacronismo, característica de la novela histórica hispanoamericana en su corriente más actual. Por ejemplo, en esta novela del autor asisten al congreso mencionado anteriormente la carroza de Quiroga llena de cadáveres, Martín Fierro, y el gaucho Cruz, Agapito Robles, personajes de Arlt, el último Mohicano, el Consejero; Arturo Cova y José María Arguedas hacen fugaces apariciones. En el congreso se rinde homenaje a Caupolicán y a Tabaré y se hacen elogios, aunque con reservas, de Haya de la Torre. Un grupo de muchachos cantan la marcha "Los muchachos peronistas". En el Congreso se escucharon informes desoladores y autocríticas despiadadas, sin que nadie planteara un plan concreto. 
"Vamos", le dice a su antiguo esclavo Nicéforo, "Aquí no queda nada por hacer. ¡Que se queden los antropólogos y los muertos!" (239). Aguirre abandona la reunión, porque no podía tolerar su fatalismo y su "retórica de la ruina".

La novela de Posse termina con un capítulo que el autor tituló EL SOL LA ETERNA FUERZA DEL AMOR, DE LA VIDA. Esta carta en el Tarot significa el fin del viaje. En la novela se recorre otra parte del pasado y la geografía latinoamericana. En este capítulo, el personaje Carrión, engendrado por Lope, es convertido en general del ejército y jefe del Poder Político. Carrión logra los sueños de poder absoluto de Lope, pero acaba por traicionar a este último. Sometido a brutales torturas por haber Ilamado a la rebelión contra el ejército militar, Lope regresa al Cuzco. Aguirre decide unirse a los grupos revolucionarios, aunque piensa conspirar contra Diego Torres, a quien Ilama "el creador de la nueva verdad obligatoria". Allí en el Cuzco se encuentra con la Mora, su amante de siglos atrás, que ahora aparece como una gitana que milita en un grupo guerrillero. Al lado de la Mora, Lope recupera las fuerzas y ve renacer el amor, el deseo sexual y su vieja rebeldía. Aguirre siente de nuevo el ansia de la acción y emprende una nueva jornada, una "Jornada grande" pero dentro de la historia, porque reconoce que "no hay otro campo para la debida traición que los hechos, la llamada Historia" (267). Aguirre muere antes de la partida, atragantado con el huesito de la suerte 
de un pato. El texto sugiere que Lope de Aguirre ha agotado sus posibilidades como personaje de la historia americana. La novela termina con signos de ambigüedad y ambivalencia hacia el estoicismo revolucionario.

En Daimón, la narración sigue el modelo del "viaje iniciático" o la peregrinación. Posse, con el lenguaje irreverente, contestatario y desmitificador de la nueva novela histórica en su corriente más actual, nos presenta a un Lope de Aguirre que de protagonista se reduce a testigo invisible de la historia. ${ }^{10} \mathrm{El}$ autor utiliza como es costumbre en sus novelas la parodia, el humor y el anacronismo para entregarnos un texto indagador y crítico de la historia hispanoamericana que mediante el uso irónico de las categorías de Civilización y Barbarie va configurando una visión crítica de la historia.

EL LARGO ATARDECER DEL CAMINANTE (1992)

\section{EL CABEZA DE VACA HISTÓRICO}

Álvar Núñez Cabeza de Vaca representa el rostro humano de la conquista española de América. A pesar de no estar entre los más conocidos, fue uno de los conquistadores españoles más interesantes del período. Cabeza de Vaca fue lo que podría llamarse un conquistador 
heterodoxo. A diferencia de otros conquistadores que se destacaron por su espíritu guerrero, y si se quiere, crueldad, Cabeza de Vaca, cuando muere a la edad de los setenta años, nunca había usado su espada para ocasionar la muerte de un ser humano. Álvar Núñez fue el verdadero descubridor de los Estados Unidos. Capturado por los indios, Cabeza de Vaca permanece cautivo seis años, pero logra huir, desde la Florida ", para iniciar a pie una travesía de más de ocho mil kilómetros, atravesando tierras inhóspitas y desconocidas, hasta que finalmente llega a México, donde se encuentra con Hernán Cortés. Regresa triunfalmente a España, y más tarde es enviado al Río de la Plata con el cargo de Gobernador. Vive en el Paraguay una nueva aventura, en la que encabeza su lucha contra la corrupción y el envilecimiento de curas y conquistadores, lucha que pierde, por lo que vuelve nuevamente a España, pero esta vez encadenado y calumniosamente acusado de lo mismo que él quiso combatir. Logra el perdón del Rey, y vive los últimos años de su vida arruinado y relegado aun por familiares y antiguos amigos aduladores. Acerca de estos avatares escribió el propio Álvar Núñez dos libros, Naufragios y Comentarios. Pero éstos contienen la crónica oficial de sus andanzas; detrás hay otra vida, señalada por la inconformidad y la condena a la exacción y al genocidio que predominaron en la conquista y colonización del Nuevo Mundo. ${ }^{12}$ Álvar 
Núñez Cabeza de Vaca probablemente sea el gran personaje moral de la conquista.

\section{NAUFRAGIOS (1542)}

Este libro de Álvar Núñez fue una anomalía en el contexto de la historiografía oficial del siglo XVI. ${ }^{13}$ Cabeza de Vaca fue uno de los pocos historiadores, que sin pertenecer a las órdenes religiosas de la época, tuvo la valentía de no describir a los indígenas americanos como salvajes. Su larga e íntima experiencia entre distintos grupos de aborígenes de América le permitió obtener un profundo conocimiento del devastador impacto de la Conquista de América. A diferencia de Álvar Núñez, los cronistas oficiales de Indias dieron a los indígenas un tratamiento desdeñoso y despreciativo. La posición oficial de Cronista Mayor de Indias era defender la conquista a toda costa. La justificación y defensa de determinados hechos de la conquista generalmente significaba una descripción negativa de los indígenas y una heroica presentación de los soldados de la corona española. Los cronistas oficiales de cierta forma tenían que combatir el legado de Bartolomé de las Casas y también la propagación de la leyenda negra por el resto de Europa. En Naufragios hay cierto tono de crítica a la presencia española en América y a la manera que España realizó la conquista. 


\section{EL LARGO ATARDECER DEL CAMINANTE: UNA REESCRITURA POSTMODERNA DE NAUFRAGIOS}

De acuerdo a las teorías de Hayden White, el discurso histórico no es más verídico que el discurso novelístico. Sus teorías cuestionan la distinción entre "discurso histórico" y "discurso ficticio" y afirman la función legítima de la imaginación en la representación de la realidad. No existe para White una base teórica válida en la cual uno pueda con legitimidad reconocer que un discurso histórico sea más válido que otro. En todo caso, tendríamos que escoger entre lo que ella llama "estrategias interpretativas" en cualquier esfuerzo para reflejar la historia. De acuerdo a las teorías de White, tendría tanta validez la perspectiva histórica reflejada en la novela de Abel Posse El largo atardecer del caminante como su texto predecesor Naufragios, como tienen tanta validez las narraciones históricas del conquistador caminante Álvar Núñez Cabeza de Vaca y las crónicas oficiales de los cronistas de Indias. Cada una responde, en última instancia, a preferencias por una modalidad de conceptualización histórica, y además, a una visión de la historia con basamento moral e ideológico diferentes.

La novela de Posse es en parte una reescritura de Naufragios por lo que el texto de Posse parte ya para su documentación, perspectiva histórica y basamento moral de un texto disidente o contestario. Naufragios nos da una visión de la conquista española y de los indígenas que no es, usando los términos de las teorías de White, "la modalidad de 
conceptualización histórica" preferida por el discurso historiográfico de los cronistas oficiales de Indias. Además, hay en la obra de Álvar Núñez un "basamento moral diferente" al de las crónicas más "oficialistas" de su época.

A su vez, la novela de Posse enmarcada dentro de la más actual corriente de la nueva novela histórica hispanoamericana difiere del texto que parodia, o sea Naufragios, del cual, además, se convierte en su tercera parte. Como acertadamente plantea Seymor Menton:

En la Nueva Novela Histórica de Abel Posse, El largo atardecer del caminante (1992), Álvar Núñez Cabeza de Vaca emprende su última caminata en Sevilla un año antes de morirse, escribiendo la verdadera historia de sus propias andanzas en la Florida y México, lo mismo que en el Brasil y Paraguay. Con una buena dosis de metaficción, el viejo conquistador caminante desmiente y complementa su propia crónica Naufragios y Comentarios. ("La historia verdadera de Álvar Núñez Cabeza de Vaca en la última novela de Abel Posse: El largo atardecer del caminante" 421)

El cronista y conquistador caminante, Cabeza de Vaca, no pudo, pese a su proximidad a los sucesos narrados, escribir "la verdad" en su discurso histórico por temor al poder del Emperador y de la Inquisición. La novela 
de Posse pudiera ser más "verdadera" que la crónica escrita por el propio conquistador y cronista.

La justificación de El largo atardecer del caminante como novela es el deseo de desmentir la historia oficial. El texto de Posse se convierte en el autodesmentido que Álvar Núñez hace sobre su obra anterior, Naufragios. Como plantea Juan Manuel García Ramos, "Lo que antes fue silenciado, ahora es referido" (Abel Posse 76), en esta novela cuando el autor recrea los seis años nómadas entre distintas tribus indias del Sur de los Estados Unidos. Seis años de su vida que, según él mismo confiesa, apenas habían sido despachados en página y media de Naufragios.

La novela de Posse, El largo atardeceder del caminante, simula ser un tercer texto de Cabeza de Vaca. En este "tercer texto" de Álvar Núñez, como hemos planteado, hay un deliberado propósito de distanciarse de la crónica oficial, pero quien marca la distancia no es el novelista, ni tampoco el narrador, sino el propio protagonista. En la novela "el conquistador caminante" se aleja de sus libros anteriores en los cuales calló muchas cosas por miedo a diferir del concepto que se tenía de la conquista en la corte española. Cabeza de Vaca corrige, en este tercer texto, a los cronistas. El largo atardecer del caminante nos presenta, entre otras cosas, el drama de este conquistador en lucha permanente con su pasado. 
La novela de Posse cuenta dos historias paralelas, una es la de los últimos años de Álvar Núñez en Sevilla; la otra, es la reescritura de sus vivencias en América. La primera es una autobiografía imaginaria en la que Cabeza de Vaca intenta entender y redimir sus errores pasados. En esta autobiografía el conquistador y cronista no niega sus culpas, aunque tampoco rechaza acusaciones. Al final, termina siendo más víctima que verdugo. La segunda es la "historia" de la conquista española en América donde el personaje Álvar Núñez Cabeza de Vaca asume las culpas de los españoles de su época. El largo atardecer del caminante recrea otro perfil de la autobiografía de Álvar Núñez: el del hambre, el cautiverio entre los indígenas y su largo caminar por las tierras americanas. Posse escribe sus propios naufragios: "No mentí demasiado en mis Naufragios [...] ¿Cómo explicar los contenidos de un mundo que no se comprende? (El largo....139-40), dice el personaje de la novela justificando su reescritura del libro. El largo atardecer del caminante se convierte en un libro que escribe otro libro.

El texto de Posse refleja la idea borgesiana de que toda literatura es, en última instancia, el arte del palimpsesto. La intertextualidad, una de las características de la nueva novela histórica hispanoamericana, está presente en la novela de Posse. A través de un ejercicio metaliterario entre el Marqués de Bradomín de las Sonatas de Ramón Valle - Inclán y aspectos descriptivos y temáticos utilizados por Arturo Uslar- Pietri en la 
novela La visita en el tiempo (1990), Posse, en esta novela, rinde homenaje a los dos autores. ${ }^{14}$ También dentro del juego intertextual, EI largo atardecer del caminante es un texto borgesiano. Borges aparece incluso como personaje agazapado. En la novela de Posse, a Borges se le nombra por su apellido materno, "Acevedo, que así se llama el ciego, habla con una intimidad ajena a hombres de verba poderosa o ingeniosa, como Bradomín o Nalé. Es más bien propenso a la sabiduría y a una reflexividad que es extraña entre los vates de la tribu ibérica" (203). ${ }^{15} \mathrm{La}$ parodia es otra de las estrategias intertextuales que utiliza Posse para enriquecer intertextualmente su novela.

En el texto de Posse encontramos varios fragmentos que son reescrituras paródicas de textos borgesianos. Por ejemplo, en El largo atardecer del caminante, se inventan seres fabulosos como en El libro de los seres imaginarios:

Es allí donde viven, cubiertos de fango fétido, los desagradables y traidores homopuevas. Hombres primigenios, seguramente anfibios, que pasan sus vidas durmiendo en el fondo de las lagunas. Dícese que emergen brevemente, movidos por el amor. No tienen cabeza. Sus ojos están en el pecho, más o menos en el lugar de las tetillas, y la boca, ancha y de finos labios femeninos, a la altura del ombligo. (145) 
Lo habíamos mandado en busca de moras salvajes y dijo haber visto animales caudados, con una cresta serrada y blanquecina, de hueso o de marfil. (146)

Además aparecen en la novela de Posse varios tópicos de la obra de Borges, como por ejemplo, la condición literaria de la realidad; la inutilidad de los excesos retóricos; la perfección estilística y el simbólico entierro del Libro, como objeto sagrado que trasciende su propia condición material. Posse recrea, con estas estrategias, el mundo particular e identificable de Borges; pero existe otro contacto más próximo entre ambos autores, el cual puede observarse tanto en El largo atardecer del caminante de Posse como en "El informe de Brodie" de Borges.

En ambos textos aparece un modo peculiar con que ambos autores transforman su materia narrativa. En ambos casos, se trata del "informe" que un viajero representante de un pensamiento eurocéntrico ofrece después de su viaje por tierras de "salvajes". El cuento de Borges, en parte, es una sátira de nuestra vanidad como "civilizados". El texto nos dice sobre los primitivos Yahoos:

Tienen instituciones, gozan de un rey, manejan un lenguaje basado en conceptos genéricos, creen, como los hebreos y los griegos, en la raíz divina de la poesía y adivinan que el alma sobrevive a la muerte del cuerpo. Afirman la verdad de 
los castigos y de las recompensas. Representan, en suma, la cultura, como la representamos nosotros, pese a nuestros muchos pecados. (Borges 379)

Por otra parte, Posse en El largo atardecer del caminante, como es común en su obra, realiza una crítica abierta de la visión eurocéntrica. En su novela, la interpretación tradicional de "civilización y barbarie", es cuestionada:

los bárbaros - ésos que mataban por centenares hombres como Narváez o Pizarro para establecer la verdadera fe eran quienes lloraban por mi desamparo condoliéndose de nuestra inhabilidad y desdicha. Nosotros, los dominadores del mundo desnudos y sin coraza ni espada, debíamos aprender de los salvajes a coger peces y raíces no venenosas. (75)

Tanto en el cuento de Borges como en la novela de Posse se utiliza el "exótico" material antropológico que brinda el viaje como un cuestionamiento de su propia cultura. Ambos textos contienen una profunda crítica al pensamiento y al discurso historiográfico oficial eurocéntrico. Posse utiliza varios recursos que son familiares a los textos de Borges, entre los cuales se encuentran, la parodia, la paradoja, el sobreentendido y la autocrítica. 
Posse, en El largo atardecer del caminante no sólo cuestiona el discurso historiográfico tradicional, como también lo hace en Daimón, sino que además intenta llenar algunos de los vacíos que la historiografía oficial no quiso o no pudo satisfacer. Las novelas de Posse Daimón, El largo atardecer del caminante y Los perros del paraíso son lo que Linda Hutcheon denomina "metaficciones historiográficas", textos, como ya hemos explicado, que mediante su autorefencialidad, subrayan el hecho de que todo discurso, incluido el histórico, sea una construcción humana que recoge, selecciona, ordena y rescribe unos hechos del pasado. La veracidad de todo discurso histórico es uno de los temas fundamentales de la obra de Posse. Cuestión que es muy debatida hoy en día por la crítica postmoderna, interesada en romper el vínculo tradicional y la correspondencia entre pasado e historia. La novela de Posse podría ser considerada como una novela postmoderna al proponer que el pasado histórico sólo se puede conocer con limitaciones, de lo cual podemos deducir que la recreación de los hechos históricos tiene un carácter limitado e inconcluso.

En la novela de Posse, el narrador duda de los historiadores que escriben la "Historia" sin haber participado o haber sido testigo de los sucesos relatados. Este cuestionamiento, presente en el texto de Posse, de la verdad histórica resulta una crítica a historiadores como González 
Fernández de Oviedo, de quien el narrador de El largo atardecer del caminante dice:

Es evidente que don Gonzalo Fernández de Oviedo, está convencido de que la Conquista y el Descubrimiento existen sólo en la medida en que él supo recuperar, organizar y relatar los hechos. Él es el dueño de lo que se suele llamar ahora "la Historia". Lo que él no registre en su chismosa relación, o no existió o es falso... (30)

Las reflexiones de Cabeza de Vaca, en el texto de Posse, puede entenderse como una crítica a determinados textos oficiales de la época colonial que fueron escritos sin que sus autores hubieran participado en la Conquista, incluso sin haber viajado nunca a América. Desde un análisis más contemporáneo, las reflexiones de Cabeza de Vaca, son también el cuestionamiento del Posse hacia toda la historia oficial que se presenta como portadora de la única y verdadera interpretación de la historia.

La historia que se propone contar Álvar Núñez al final de su vida, en este "tercer libro" que es la novela de Posse, no tiene destinatario al monarca español, como los textos anteriores, Naufragios y Comentarios, donde el autor tuvo que manipular sus experiencias con el objeto de agradar al Rey. La creación de los Naufragios estuvo condicionada por una serie de intereses futuros que desembocaron en la concesión por 
parte de Rey al autor de los títulos de Adelantado y Gobernador del Río de la Plata. Ahora, en la novela de Posse, Cabeza de Vaca tiene libertad de contar la verdad de lo sucedido:

..no había ojos que amenazasen la libertad de expresarme; porque los ojos del otro son el fin de nuestro yo, de nuestra espontaneidad. [...] Y desemboqué en el lujo de la libertad. Una libertad de papel. Una nueva forma de caminar, de aventurarme por los desiertos, adecuada para el viejo que ya soy. (38)

Así comienza el viejo conquistador, al final de su vida, a narrar la "verdadera" historia de sus experiencias en tierras americanas pero conciente de que sólo a sí mismo puede contarse su verdadera vida.

En el texto de Posse, el narrador nos habla de los sucesos en los que Cabeza de Vaca no se extendió y de los vacíos discursivos que dejó en Naufragios, donde destacan los seis años que pasó con los indios chorrucos y a los que dedicó en un principio sólo una página y media de su obra. Ahora, Álvar Núñez opina sobre la explicación que dio para omitir en su obra anterior sus seis años de esclavitud:

Releyéndome ahora, encuentro que mi silencio de seis años resuelto con página y media de mi libro, es lo suficientemente descarado y evidente como para que los estúpidos inquisidores de la Real Audiencia y del Consejo de 
Indias no sospechasen nada. [...] Me reí de mi descaro: escribí que soporté seis años de esclavitud porque esperaba que se repusiese Lope de Oviedo, oficial de Narváez, de su enfermedad. Aparezco así como el más abnegado caballero cristiano." (77-8)

La confesión de Cabeza de Vaca apoya el criterio de como lo que se conoce como la "Historia", o sea el discurso oficial, puede estar sujeto a manipulaciones de la verdad por diferentes razones.

El narrador en el texto de Posse, contrariamente a lo que afirma en sus Naufragios, confiesa que ni siquiera intentó escaparse de las diferentes tribus con las que convivió pero "[u]na secreta voz me tentaba para seguir andando detrás del sol, en dirección opuesta a la de mi mundo" (79). El texto de Posse abunda además, a diferencia de Naufragios, en el largo tiempo que Cabeza de Vaca tuvo con los indios chorrucos de los cuales recibió trato amistoso y se le permitió formar una familia. Su mujer Amaría y sus hijos le reportaron mucha felicidad, la cual el autor compara con el Paraíso Terrenal.

En la novela de Posse, Cabeza de Vaca confirma el carácter mediatizado de todo discurso histórico y la imposibilidad de cualquier recreación mimética de la realidad. "No recordamos lo que nos dijeron, lo que pasó, sino más bien, lo que nos dijeron y que nos pasó" (90). También el narrador hace referencia al carácter fabulador de cualquier 
discurso: "Lo más fascinante de la mentira literaria es la facultad para acumular detalles. La historia termina siendo más interesante que la verdad" (103). Además, el personaje y narrador, en El largo atardecer del caminante es consciente de que esto no será comprendido en su época. El protagonista de Posse lo reconoce cuando dice: "un secreto para nosotros. O para hombres de otra época, no de ahora" (184). Se trata, como asegura Seymour Menton, de "una revelación percibida, sólo por el hombre mestizo, el nosotros, o 'el otro' en terminología actual" ("La historia verdadera" 423). Este nosotros, empleado por el narrador para autodefinirse, es el resultado de la condición de alteridad entre la cultura europea y la indígena, a las que estuvo expuesto Álvar Núñez después de una larga convivencia con los grupos amerindios.

La larga convivencia con los indígenas no solamente modificó la percepción que hasta ese momento el personaje histórico tenía del "otro" sino que hizo que se identificara en parte con la "nueva" cultura de la que formó parte durante ocho años. Esto trae como resultado que el personaje de Cabeza de Vaca adquiera y sea visto como un personaje con características biculturales. Esta condición bicultural en Naufragios es sólo parcialmente mostrada. En El largo atardecer del caminante el narrador reconoce la imposibilidad de compartir su "secreto" en una época en que no lo entenderían. De ahí que sea necesario ocultar esta "verdadera historia" de su vida, entre los tomos de la biblioteca de la 
Torre de Fadrique, para que un lector del futuro pueda recuperar la historia y reinterpretarla.

En conclusión, podemos decir que El largo atardecer del caminante, enmarcada dentro de la corriente más actual de la novela histórica hispanoamericana, es una reescritura postmoderna de Naufragios y simula ser una tercera parte de la misma. Cabeza de Vaca, en la novela de Posse, desmiente y complementa sus primeras crónicas. La novela de Posse desmiente el discurso oficial y nos presenta el drama de este conquistador con su pasado. Es un texto que refleja la idea de Borges de que toda literatura es, en última instancia, un palimpsesto. La intertextualidad de esta novela de Posse nos remite, entre otros, a ValleInclán, Uslar- Pietri y Borges. El texto de Posse intenta llenar los vacíos que el discurso historiográfico no ha podido satisfacer. El tema del viaje, presente en la literatura hispanoamericana desde nuestros textos fundacionales, sirve, en esta novela y también en Daimón, para cuestionar el pensamiento eurocéntrico en el cual se apoya el discurso historiográfico oficial. 


\title{
NOTAS
}

\begin{abstract}
' Ver Emiliano Jos. La expedición de Ursúa al Dorado y la rebelión de Lope de Aguirre. Para este trabajo se consultó y se usó el resumen de los acontecimientos de Ingrid Galster en su trabajo "El conquistador Lope de Aguirre en la Nueva Novela Histórica".

${ }^{2}$ En 1947 se publicó El camino de El Dorado de Arturo Uslar Pietri y en 1964 La aventura equinoccial de Lope de Aguirre de Ramón J. Sender.
\end{abstract}

${ }^{3}$ Ver García Pinto, Magdalena. Entrevista con Abel Posse. En esta entrevista el autor abunda sobre los escritores que influyeron en su formación literaria.

${ }^{4}$ En Daimón, Posse retoma la historia de la rebelión de Lope de Aguirre y sus hombres a partir de variados textos documentales y novelísticos. Están las tres cartas de Aguirre, una dirigida al padre Montesinos, otra al gobernador Collados y la tercera al rey Felipe II. Se conservan alrededor de diez relaciones escritas por testigos presenciales y diversas cartas y declaraciones acerca de los sucesos.

${ }^{5}$ De aparición casi simultánea con Daimón está la novela la Lope de Aguirre: Príncipe de Libertad (1979) de Miguel Otero Silva. La novela de Otero Silva rehabilita la figura de Aguirre y podría considerarse una novela "revisionista" deliberadamente.

${ }^{6}$ La novela de Posse representa una ruptura con la historia oficial identificada con los vencedores. El texto de Posse invita al debate. Daimón es parte de una trilogía de novelas del mismo autor que intentan des-cubrir el "descubrimiento" y la conquista.

7 En Postmodern Fiction McHale señala lo siguiente:

Apocryphal history, creative anachronism, historical fantasy - these are typical strategies of the postmodernist revisionist historical novel. The postmodernist historical novel is revisionist in two senses. First, it revises the content of the historical record, reinterpreting the historical record, often demystifying or debunking the orthodox version of the past.

Secondly, it revises, indeed transforms, the conventions and norms of historical fiction itself. (90)

El autor abunda sobre el concepto de "anacronismo creativo" en la misma obra, en la página 93.

${ }^{8}$ La teoría del Eterno Retorno es analizada con detalles en la obra El mito del eterno retorno de Mircea Eliade a quien Posse menciona en algunas páginas de su obra. El concepto del Retorno está relacionado con el de la Conquista de América; pues, según Eliade: "El establecimiento de una región nueva, desconocida e inculta equivale a un acto de creación" (19). La tradición del concepto del eterno retorno tiene como finalidad la de rechazar el concepto de Historia. Este concepto es afín al de Jorge Luis Borges cuyas ideas de la concepción cíclica, la teoría del eterno retorno, aparecen desarrolladas en "La doctrina de los ciclos", en "El tiempo circular" y en Historia de la eternidad. La obra de Borges y de Lezama Lima fueron fundamentales en la formación intelectual del Abel Posse.

${ }^{9}$ El personaje Lope de Aguirre, en la novela de Posse, representa al conquistador español, pero al mismo tiempo resulta atípico: enemistado con el Dios cristiano, es partidario del Demonio. Esta singularidad, también fue puesta de relieve de manera 
diversa por Uslar Pietri en Las lanzas coloradas (1947) y por Otero Silva en Lope de Aguirre, Príncipe de Libertad (1978-1979).

${ }^{10}$ Daimón es una novela metahistórica: propugna una perspectiva totalizadora e interpretativa sobre la historia de Hispanoamérica desde la conquista.

${ }^{11}$ La Florida abarcaba toda la zona del Golfo de México, incluyendo los estados actuales de Florida, Alabama, Mississippi, Lousiana y Texas.

${ }^{12}$ Para este trabajo se consultó y se usó el resumen biográfico realizado por Alexis Márquez Rodríguez en Abel Posse. El liibro recoge las conferencias que sobre el autor se celebró en Madrid del 20 al 23 de noviembre en Casa de América en el año 1977.

${ }^{13}$ El libro de Álvar Núñez Cabeza de Vaca que hoy se conoce como Naufragios fue publicado inicialmente con el título La relación y Comentarios del gobernador Alvar Núñez Cabeza de vaca, de lo ascendido en la jornada que hizo a las indias.

${ }^{14}$ Ver en La novela histórica hispanoamericana desde 1931 hasta nuestros días de Antonio Usable González como el autor explica con detalles el vínculo intertextual de la novela de Posse, las Sonatas de Valle - Inclán y La visita en el tiempo de Uslar- Pietri. En Historia, ficción y metaficción en la novela latinoamericana contemporánea Esther Smith tiene un interesante trabajo sobre La visita en el tiempo titulado "La novela en la historia: un encuentro metaficcional".

${ }^{15}$ El abuelo materno de Jorge Luis Borges se llamó Isidoro Acevedo, en cuya casa de Buenos Aires nació el célebre escritor argentino el 24 de agosto de 1889. 


\section{Quinto capítulo: El arpa y la sombra}

\section{INTRODUCCIÓN}

Si analizamos la trayectoria de la nueva novela histórica hispanoamericana desde sus inicios con la publicación en 1949 de $E I$ reino de este mundo hasta nuestros días, podemos notar dos corrientes. Una primera corriente donde ya se realiza una relectura de la historia que puede estar fundada en el historicismo- crítico, como es el caso de Alejo Carpentier con su narrativa didáctica - histórica de la cual son excelentes muestras El reino de este mundo y El siglo de las luces. Ambas novelas se edifican sobre el respeto a la "reconstrucción" histórica. Esta primera tendencia de la nueva novela histórica hispanoamericana se destaca por el rigor documental e informativo. En estas novelas, es frecuente la recreación fidedigna de los contextos sociales y culturales dentro de los cuales se mueven los personajes y transcurren los eventos narrados en el texto.

La segunda y actual tendencia de la nueva novela histórica hispanoamericana, que se inicia con la publicación en 1969 de El mundo alucinante de Reinaldo Arenas, se caracteriza por un discurso ficcional caracterizado por la reescritura irónica y paródica, carnavalizada, irreverente del discurso historiográfico tradicional.' La nueva novela en su corriente más actual roza la hipérbole, lo grotesco, y en ella abunda la 
intertextualidad, la polifonía, el dialogismo y el anacronismo como instrumentos que intentan deconstruir creencias y valores establecidos por la historia oficial y desmontar la posibilidad de conocer "las verdades" de la historia. Esta segunda tendencia de la nueva novela histórica hispanoamericana se adscribe al modo conocido como metaficción historiográfica, la cual es considerada una manifestación del postmodernismo internacional.

Las ideas de Elzbieta Sklodowska en su trabajo La parodia en la nueva novela hispanoamericana apoyan lo planteado en el párrafo anterior. Sklodowska plantea que:

la reescritura de la historia hispanoamericana - tal como aparece en la nueva novela - está enmarcada por dos fuerzas. La primera - centrípeta- es la que lleva a la novela a preservar el modelo estructurador/totalizador de un discurso homogéneo (realista o mítico), a la vez refuncionalizándolo con el objetivo de contestar con la verdad a las mentiras. La segunda fuerza - centrífuga, auto-reflexiva, metaliteraria convierte a la novela en un objeto irreverente de su propia teleología. (29)

Según el punto de vista de Sklodowska, cuando lo que se conoce como el Boom en la literatura hispanoamericana llega a su fin, es el momento en 
el que la nueva novela histórica empieza a alejarse rápidamente de la primera tendencia.

En 1979 sorprende Alejo Carpentier con la publicación de El arpa y la sombra. Carpentier, "el más solemne y riguroso de los autores de la generación anterior" (Aínsa, "La nueva novela" 84), intuye en El arpa y la sombra las posibilidades literarias de esta dirección. El autor ofrece a través de ésta, su última novela, su testamento literario mediante una reconstrucción paródica, carnavalizada, revisionista del discurso historiográfico tradicional. Carpentier, con su última novela, se vincula a la corriente más actual de la nueva novela histórica hispanoamericana.

En esta novela hay un cuestionamiento de algunas "verdades" históricas, pero el texto de Carpentier tampoco intenta establecer una verdad nueva ni definitiva, lo cual está en concordancia con los postulados de críticos descontruccionistas, como Derrida, Barthes o Lacán, que establecen que no existe un significado definitivo o verdadero sino intentos de aproximación de lecturas críticas que corrigen otras lecturas. El arpa y la sombra se adscribe al postmodernismo internacional, como plantea Santiago Juan-Navarro,"sobre la base del uso que Carpentier hace de la autoconciencia literaria, el revisionismo historiográfico y la parodia de las grandes narrativas y mitos del origen" ("El arpa y la sobra". n. pag.). El arpa y la sombra reúne muchos de los rasgos paradigmáticos de lo que Seymour Menton y Fernando de Aínsa 
califican como nueva novela histórica hispanoamericana y ejemplifica lo que teóricos como Linda Hutcheon y Brian McHale han denominado metaficción historiográfica y ficción postmodernista, respectivamente.

La última novela de Carpentier es un collage de diarios de viaje, biografías, crónicas, libros de ficción y obras literarias, que son incorporadas como un intertexto literario. Por eso, podemos decir que en El arpa y la sombra se da una relación intertextual general, o sea, la que se produce entre textos de diversos autores. En la novela de Carpentier, se sintetiza, a manera de collage intertextual, el Diario de Viaje, y cartas de Colón, biografías de varios autores sobre él y diferentes puntos de vista de la historiografía tradicional y contemporánea, así como, elementos de otras obras literarias. ${ }^{2}$ También encontramos en la primera parte de la novela un collage intertextual con textos como la versión oficial de la misión vaticana a Chile en el siglo XIX, así como una relación del viaje escrita por Giuseppe Sallusi (que en la novela de Carpentier es mencionado como Salustio) publicada en 1827 y traducida al español en 1906. Además, existe en EL arpa y la sombra un diálogo intertextual con el uso anacrónico de expresiones y textos colombinos de Carpentier, así como alusiones al "retablo de maravillas" de Cervantes, y paráfrasis de versos de "La casada infiel" de García Lorca. ${ }^{3}$ También aparecen recreaciones de fragmentos de textos fundamentales de la literatura hispanoamericana como "El Matadero" de Esteban Echevarría y del 
Facundo de Domingo Faustino Sarmiento. Carpentier en su novela elabora una recreación histórica precisa de la época, pero al mismo tiempo dicha recreación se subvierte con el uso anacrónico de textos literarios.

Dividida en tres partes, esta novela, adopta la disposición de un tríptico que el autor subtitula: "El arpa", "La mano" y "La sombra". Carpentier muestra una vez más lo que ha sido una constante en su producción narrativa, su preocupación por la estructura de sus obras. Como acertadamente sugiere Leonardo Acosta, El arpa y la sombra: nos ofrece esta vez una especie de Auto Sacramental en tres partes, siguiendo el principio ternario de la Santísima Trinidad y del arte cristiano medieval hasta su culminación en Dante. El arpa, instrumento celestial, acompaña en su periplo al Jefe de la Iglesia Romana; la mano es la del ávido navegante genovés y se mantiene desmesuradamente para descubrir nuevas tierras que redondean nuestro Orbe, y para otras cosas... La sombra es el umbral de Hades o del Infierno dantesco, ante el cual dialogan vivos y muertos. Tenemos así: Cielo, Tierra- Infierno, esquema clásico. ("El almirante según don Alejo" 28)

Otros ensayos sugieren equivalencias tales como: Paraíso, Purgatorio e Infierno; Roma, Yo y los demás; o El arpa (el ideal, la Utopía), La mano 
(la praxis, la acción) La sombra (el hálito espiritual, la presencia interna de lo Uno).

La primera y tercera parte de la novela exploran la propuesta de beatificación de Colón emprendida por Pío IX en el siglo XIX. Estas dos partes enmarcan la parte central de la novela donde el Almirante ofrece un recuento apócrifo de su vida ante la inminencia de la muerte. (La muerte es una presencia constante en esta novela). En la segunda parte es donde el Almirante, esperando al confesor en el lecho de muerte, ofrece al lector una visión alternativa de las biografías que conforman el discurso historiográfico oficial.

En la narratalogía contemporánea, Genette señala la existencia de diferentes relatos, atendiendo a la posición del narrador de una historia frente a los acontecimientos relatados. De acuerdo a las ideas de Genette, podemos decir que la primera parte de esta novela está narrada en tercera persona, es un relato heterodiegético, o sea, un relato en el cual el narrador está fuera de la historia que cuenta:

Algo fatigado, el sumo Pontífice, se adormeció levemente, en tanto que se desprendían, por rangos y categorías, los dignatarios del séquito, invitados, a no seguir adelante, más allá de este u otro umbral en observancia del estricto protocolo de ceremonia. (El arpa y la sombra 221) 
En la segunda parte de la novela la historia es contada, en primera persona, por una narrador autodiegético, o sea, un narrador que es protagonista de, lo narrado, es un monólogo de Colón mientras espera a su confesor:

Como yacente en lápida de piedra espero a quien habré de hablar muy largo, ahorrando ánimos para hablar tan largo como habré de hablar, más vencido, acaso, por los muchos trabajos, padecidos que por la enfermedad...Y habrá que decirlo todo. Todo, pero todo. (El arpa y la sombra 255)

La tercera parte de la novela, como sucede en la primera, está narrada en la tercera persona, y es un relato, de nuevo, heterodiegético:

El Invisible - sin peso, sin dimensión, sin sombra, errante, errante transparencia para quien habían dejado de tener un sentido las vulgares nociones de frío o calor, día o noche, bueno o malo - llevaba horas vagando entre los brazos abiertos de las cuádruples columnatas de Bernini, cuando se abrieron las altas puertas de San Pedro. (El arpa y la sombra 351)

Las diferentes voces narrativas de la novela contribuyen a formar el carácter dialógico y polifónico de El arpa y la sombra.

Los términos "dialogismo" y "polifonía" han sido utilizados por Bajtín, en sus estudios sobre Rabelais y Dostoievsky, para aludir a la 
mezcla de voces y diversos tipos de discursos que conviven y en un texto literario. El arpa y la sombra es una novela polifónica donde se mezclan las diferentes voces narrativas, la del autor los personajes. Este fenómeno de desdoblamiento, convergencia o diferencias entre las distintas voces presentes en la novela confiere ese carácter polifónico y dialógico a El arpa y la sombra, a la vez que conforma una opinión pluridiscursiva sobre el tema de Colón y el descubrimiento de América.

A través del narrador heterodiegético y de las ideas del personaje, Mastai, en la primera parte de la novela podemos escuchar el discurso y las voces de los biógrafos, historiadores, novelistas y dramaturgos que han contribuido a crear una visión hagiográfica, apologética y mitificada de Colón. Por otro lado, el monólogo de la segunda parte de la novela está en concordancia con el discurso historiográfico desmitificador que ha venido cuestionado la visión hagiográfica de Colón y entona con las voces de los investigadores que empezaron a cuestionar el discurso historiográfico apologético sobre el Almirante.

Los diferentes puntos de vista sobre la figura de Colón y el Descubrimiento de América son controvertidos. Tanto el discurso apologético como el discurso desmitificador están presentes en la novela. Carpentier toma partido por el último de éstos. ${ }^{4}$ Es evidente que la intencionalidad de la novela es la sátira y la desmitificación de Colón. La 
controversia contribuye a crear un clima de ambigüedad y escepticismo en la última novela de Carpentier.

El arpa y la sombra tiene dos protagonistas que son personajes históricos de diferentes siglos: Mastai Ferretti y Cristóbal Colón. La semejanza entre Ferretti, Colón y Carpentier ha sido debidamente establecida en varios ensayos. Roberto González Echevarria, por ejemplo, fundamenta la semejanza de manera explícita:

La identificación de Carpentier con Colón es evidente y es lo más sugestivo en El arpa y la sombra, ya que por supuesto, en el esquema convencional de la historia de la literatura hispanoamericana, los textos de Colón constituyen el inicio de la tradición narrativa, el principio sin principio, la escritura de fundación. [...]Pero, por supuesto, Colón no es la única imagen de Carpentier que tenemos en El arpa y la sombra; está también Mastai Ferretti, es decir, Pío IX. [...] La identificación de Carpentier con Pío IX es evidente, por irónica que sea. Como Carpentier, Mastai es hombre de dos mundos, ya que su periplo por América lo ha identificado con lo hispanoamericano, así como también sus lecturas de textos no sólo hispanoamericanos sino españoles. Su erudición, su barroca figura llevada en andas por los corredores del Vaticano, es una clara proyección de 
Carpentier que, medio en broma, se disfraza no ya de Papa sino de gran señor barroco. (“Carpentier y Colón” 161-62) Mastai y Colón, parafraseando a González Echevarria, representan dos fuerzas contradictorias que constituyen la figura fundamental en la narrativa hispanoamericana: el archivo, como receptáculo de secretos, poseedor de la primera regla, del poder de la autoridad.

\section{EL MASTAI FERRETTI HISTÓRICO (PÍO IX)}

Giovanni María Mastai- Ferretti protagonizó el más largo pontificado de la Iglesia Católica: treinta y dos años. Cuando ascendió al solio de Pedro, en 1846, con 54 años de edad, se había granjeado, hipócritamente, una esperanzadora fama de sacerdote liberal, amigo de posturas dialogantes y moderadas. Le tocó ser el último Papa con poder de príncipe temporal sobre los Estados Pontificios, que resultaron absorbidos por la unificación de Italia. Tal limitación lo alertó seriamente contra la política externa, a la que no supo ni quiso aproximarse. Ni la burguesía en alza ni los movimientos proletarios contaron con su apoyo, y habrían de esperar hasta los tiempos de su sucesor León XIII para comenzar a obtener respuestas.

Epiléptico, desde muy joven se mostraba irascible, terco y rencoroso con quienes se le enfrentaban, en lo que se ha interpretado 
como una falta evidente de caridad cristiana. Apartó de la curia a teólogos sospechosos de confraternizar con posturas transigentes, con todo cuanto cuestionara un dictamen único. Acérrimo partidario de la Divina Providencia, de una historia humana dirigida desde lo alto, exaltó la fe en Dios y en su sola Ley por encima de la razón y de la ciencia. Era un integrista que se sentía asistido por la privilegiada iluminación de la Gracia, y por tanto, superior en juicio a cualquier iniciativa de legislación temporal. ${ }^{5}$

En 1854, promulgó el famoso dogma de la Inmaculada Concepción de María; en 1864, como colofón a la encíclica Quanta cura, redactó las ochenta proposiciones o enmiendas del Syllabus de errores del mundo moderno. Y en 1869, justo cuando había comenzado a extraviar sus dotes de príncipe terrenal, propone, en el Concilio Vaticano I, la aprobación de su sello infalible, que consigue a pesar de la oposición de determinados sectores.

Con Mastai-Ferretti, la iglesia se replegó sobre sí misma, exigiendo obediencia ciega a su código de dogmas, y desoyendo cualquier ingerencia de la vida pública exterior. Aterrada por los efectos convulsivos de la Revolución Francesa y de la Revolución Industrial, condenó el parlamentarismo, la soberanía popular, la separación de Iglesia y Estado, la libertad de prensa, cultos y conciencia, los derechos civiles y la limitación del poder papal en el centro de Italia. Pío IX, 
creyéndose imprescindible, centralizó la estructura del gobierno alrededor de él, siendo adorado como verdadero Vicario de Cristo en la tierra, como la imagen visible de lo Invisible.

A Pío IX se le recuerda como personaje vinculado más a los asuntos humanos que a los espirituales. Su beatificación ha sido relegada a ese limbo reservado a aquéllos cuyas virtudes personales no son suficientes para rendirle los más elevados honores de la Iglesia ${ }^{6}$

\section{LA DESMITIFICACIÓN DE COLÓN}

El discurso ficticio referente a Cristóbal Colón en El arpa y la sombra crea una tensión con la imagen que el discurso historiográfico tradicional ha creado de él. La novela de Carpentier desmitifica al "descubridor" de América, el héroe que la "historia" había mitificado por haber realizado uno de los mayores acontecimientos históricos de la humanidad. En su última novela, por primera vez, el autor convierte a una figura central de la historia en uno de los protagonistas de su obra. En sus obras anteriores Carpentier rescata personajes históricos marginados u olvidados por el discurso historiográfico oficial. Así sucede en El reino de este mundo donde se recrea la vida de Henri Christophe, verdadera "rareza" histórica que comparte el texto de Carpentier con Bouckaman, el mítico Mackandal, entre otros personajes marginados de la historia. En El siglo de las luces rescata del olvido a Víctor Hugues que 
comparte la novela con personajes de ficción y otros de cierto rango histórico, pero que no alcanzan tener nivel protagónico en la narración.

Sorprende Carpentier al escribir una novela sobre Colón, una figura tan relevante como controvertida, a la cual la historiografía ha dedicado muchas páginas. En una entrevista concedida en 1978, el autor hace la siguiente observación sobre personajes históricos muy conocidos:

No se puede hacer una gran novela cuyo personaje central se Ilame Napoleón Bonaparte, o se llame Julio César, o se llame Carlomagno, porque o bien se achica el personaje con las exigencias de lo relato novelesco, o bien, por un prurito de fidelidad, no se colocan en su boca sino palabras que realmente dijo, los discursos que realmente pronunció y entonces se transforma el gran hombre en una especie de monumento, con facultad de movimiento, pero que pierde fuerza. (Entrevistas 377-78)

Posteriormente, en el año 1979, en una conferencia que dio el autor sobre EL arpa y la sombra, Carpentier explica que en el caso de Colón había circunstancias favorables para hacer del Almirante uno de los protagonistas de su novela: "Todo en la vida de Cristóbal Colón es misterio. [...] Las lagunas subsisten, numerosas, enormes, en la obra de Colón." (Carpentier, Sobre El arpa y la sombra 174- 75). La existencia de amplios "vacíos" en los textos que intentan reconstruir la vida de Colón y 
la controversia existente entre los escritores que han contribuido a crear una visión hagiográfica de Colón y los que han estudiado la vida del Almirante quizá con más rigor histórico y, por consiguiente, con menor fervor llevaron a Carpentier a escribir El arpa y la sombra.

Los panegiristas de Colón se basan en tres fuentes denominadas "colombinas". La primera fuente es la Historia de Cristóbal Colón, escrita por el biógrafo francés Roselly de Lorgues, encargada por el Papa Pío IX en 1851. La segunda es la obra del novelista e hispanófilo norteamericano Washington Irving, autor de The life and voyages of Christopher Columbus, publicada en 1828. La tercera fuente, las piadosas falsedades propiciadas por el propio Colón y a su hijo y biógrafo Fernando Colón, de quienes el fraile Bartolomé de Las Casas tomó los datos sobre el Almirante que integran su Historia de las Indias. ${ }^{7}$

Entre los primeros investigadores que empezaron a cuestionar y desmantelar la visión idealizada y hagiográfica de Colón se encuentran Alejandro de Humbold con su Examen critique de la geographie du monde (1836-39), Henry Harrise y su obra Christophe Colomb (1884), Sophus Ruge con Columbus (1902). Las ideas, de Henri Vignaud, contra los que él Ilamó "la leyenda de Colón" cuyos argumentos aparecen resumidos en su libro Cristóbal Colón y la leyenda (1947), son las que han ido más lejos al poner en duda la concepción de que Colón, 
descubrió América en su empeño de encontrar una ruta hacia las Indias, o sea, el Oriente asiático.

Carpentier toma partido a favor de la desmitificación de Colón haciendo uso, para lograr su objetivo, de diferentes registros del humor, tales como la ironía, la sátira, y lo grotesco. El rechazo del autor a la obra apologética de León Bloy sobre Colón y a la obra dramática que Paul Claudel tituló El libro de Cristóbal Colón , y de la cual Carpentier realizó una adaptación radiofónica en 1937, fue el germen de la idea para escribir El arpa y la sombra. "Hay elementos que siempre me irritaron en la mayoría de los textos dedicados a Colón, como su aspecto hagiográfico prefabricado" (Palabras en el tiempo de Alejo Carpentier 3637). Carpentier en su novela se aleja de la construcción hagiográfica y mitificadora de Colón. ${ }^{9}$ El autor de El arpa y la sombra toma una distancia de separación, respecto del personaje que reconstruye, que le permite hablar de él con justicia, sin denigrarlo ostentosamente, pero tampoco aparentando ser su apologista.

\section{EL ARPA}

La primera parte de la novela, caracterizada por la solemnidad, introduce al personaje central de esta parte de la novela: Mastai Ferretti, personaje con el cual el autor logra una identificación inicial estableciéndose una proyección autobiográfica. Como Carpentier, Mastai 
Ferretti conoce el castellano y el francés, es lector erudito, gran conocedor de los clásicos españoles y franceses y hombre de dos mundos. En esta primera parte también se establece una relación de semejanza entre Mastai Ferretti y Colón: ambos son lectores, autores, poseedores de secretos y de autoridad; a ambos los une la ambición y la controversia.

La primera parte de El arpa y la sombra es una solemne reflexión hagiográfica del Papa Pío IX. Carpentier nos presenta al Papa Pío IX, acodado en la mesa de su despacho, reflexionando acerca de la verdad sobre Colón, por medio de un viaje a Argentina y Chile que realizó en su juventud, piensa cuánto se asemeja la personalidad del Almirante a la de él mismo: ambiciosa, hipócrita, dispuesta a predicar una ideología y ejecutar luego otra por estricta conveniencia; fingidora, en suma “...Por su grande habilidad en manejarse con el pensamiento adverso, ascendería al pontificado con la reputación de hombre sumamente liberal y amigo del progreso (Carpentier, El arpa y la sombra 43). Sí, aquel marino se parecía bastante a él en varios aspectos.

El Papa Pío, en su despacho, rememora sus tiempos de joven Mastai, cuando, por motivos de apostolado, visitó Buenos Aires y Santiago de Chile. Hijo de un aristócrata venido a menos, tuvo que aprovechar cualquier oportunidad que se le ofreciera dentro del sacerdocio para escalar posiciones: 
Ordenado sacerdote, se distingue por el ardor y la elocuencia de sus predicas. Pero sabe que lo espera un camino largo y difícil, sin esperanzas de ascender hacia las altas jerarquías eclesiásticas [...] Y todo es obscuridad, humildad y resignación en su vida, cuando se produce el milagro: Monseñor Giovanni Muzi, arzobispo de Filipópolis, la de Macedonia, cuna de Alejandro Magno, nombrado Delegado Apostólico en Chile, ruega a Mastai que lo asesore en una muy delicada misión [...] [p]iensa que el joven canónigo puede serle de suma utilidad, por su cultura general, y en particular, por su conocimiento del idioma castellano. (EI arpa y la sombra 230)

La acción de la novela en esta parte inicial se sitúa en el siglo XIX. EI joven Mastai salió para Chile como parte de la misión vaticana, tal como se narra en la novela, en 1823 . Otros personajes históricos se citan en esta primera parte: el artista italiano Miguel Ángel. Catalina de Hiena, Urbano VI, Napoleón III, Roselly de Lorgues, Napoleón Bonaparte, Baltasar Gracián, Voltaire, Rousseau, el abate Marchena, Alejandro Magno, Bernardo O’Higgins, Francisco Miranda, Simón Bolivar y Catalina de Rusia.

La primera parte de El arpa y la sombra es, entre en otras cosas, una síntesis de la situación política, religiosa y artística del siglo XIX en Europa y en América, vista a través del personaje Mastai Ferretti, futuro 
Papa Pío IX. La Iglesia católica se encontraba en un estado de cierta vulnerabilidad política después de los procesos que dieron lugar a la independencia de gran parte de las actuales naciones hispanoamericanas. Bernardo O'Higgins cuando estuvo al frente del gobierno invita a una misión vaticana a visitar a Chile con la intención de reorganizar la iglesia chilena controlada por el clero español. Carpentier lo recoge en El arpa y la sombra:

O’Higgins sabía que España soñaba con restablecer en América la autoridad de su ya menguado imperio colonial [...] Y sabiendo que la fe no puede extirparse de súbito como se acaba, en una mañana, con un gobierno virreinal o una capitanía general, y que las iglesias hispanoamericanas dependían, hasta ahora, del episcopado español, sin tener que rendir obediencia a Roma, el libertador de Chile quería sustraer sus iglesias a la influencia de la ex metrópoli - cada cura español sería mañana un aliado de posibles invasores -, encomendándolas a la autoridad suprema del Vaticano. (232-

El sacerdote Mastai fue invitado por el jefe de la misión vaticana que viajaría a Chile debido a sus conocimientos del castellano. El Mastai histórico escribió un diario durante el viaje que incluyó paradas en Montevideo y Buenos Aires. ${ }^{10}$ 
La versión oficial del viaje fue escrita por el abate Giovanni Muzi y editada por jesuitas y, otro miembro de la comitiva. Giuseppe Sallusti (mencionado en la novela de Carpentier como Salusio, secretario de Muzi), publicó una relación del viaje que fue traducida al español en 1906." En la primera parte de El arpa y la sombra encontramos un collage intertextual con los diarios de viaje de Sallusi y Muzi y pasajes de las cartas de Mastai. También enriquecen el collage pasajes de obras fundamentales de la literatura hispanoamericana como "El Matadero" de Esteban Echevarria y Facundo de Domingo Faustino Sarmiento.

El Buenos Aires del siglo XIX que conoció Mastai, según aparece descrito en el texto de Carpentier, deviene en imagen paródica de "El Matadero":

Buenos Aires ni siquiera tenía puerto, sino una mala bahía, de donde había de alcanzarse la ciudad en una carreta tirada por caballos, escoltada por hombres a caballo, en hedor de caballos. Olores de cuero bruto y trompería de relincho.[...] los vestidos salpicados de sangre de las negras que traían achuras del matadero - ese matadero - de tal importancia, al parecer, en la vida de Buenos Aires, que llegaba Mastaï a preguntarse si, con el culto del Asado, el Filete, el Lomo, el Solomillo, el Costillar - o lo que algunos, educados a la inglesa, empezaban a llamar Bife - el Matadero no resultaría, 
en la vida urbana, un edificio más importante que la misma

Catedral. (El arpa y la sombra 235-36)

El Buenos Aires del siglo XX es recordado por Mastai como una aldea atrasada, llena de caballos y carretas de bueyes. Un lugar, que en todos sus rincones, huele a matadero y a cuero curtido.

En esta misma primera parte de la novela aparece otro pasaje que enriquece el collage intertextual de El arpa y la sombra. Este fragmento nos ofrece una visión de la pampa similar a la expuesta en Facundo:

El paisaje era de una agobiante monotonía, pero acababa por imponerse a su atención por una razón de escalas. Creía saber lo que era una llanura, pero la visión de la pampa infinita donde, por más que se anduviese, se estaba siempre al centro de un redondo horizonte de tierra monocorde: la pampa, dando al viajero la impresión de que no se movía, ni adelantaba en su rumbo, por mucho que arreara los brutos de tiro; la pampa, por su vastedad, por su cabal imagen del infinito que situaba al Hombre ante una presente figuración de lo llimitado... (238)

Esta novela de Carpentier, adscrita en la corriente más actual de la nueva novela histórica hispanoamericana, reescribe la historia, utilizando el pastiche y la parodia de textos literarios para incorporar el pasado histórico y literario a un texto postmoderno. 
El arpa y la sombra es un buen ejemplo de reescritura irónica, paródica y carnavalesca que reflexiona sobre la historia a la vez que reconstruye el discurso historiográfico tradicional. Esta primera parte de la novela está narrada mediante una voz narrativa omnisciente que habla en tercera persona. El narrador omnisciente sabe todo lo que hacen y piensan los personajes, así como los motivos de cada acción que ejecutan. El narrador no sólo comunica los hechos sino que también los interpreta. De esta manera según plantea Antonio Fama: "en la narración se consigue un tono de censura, sea de la conducta del papa o de la de Colón" ("Historia y narración" 548). Ese tono de censura está relacionado con la intencionalidad de la obra, en la cual subyace un tono satírico y un motivo picaresco, que Posse hereda de la tradición literaria hispánica pero que también conforma parte del carácter carnaverlesco de esta novela. Veamos un ejemplo de cómo se manifiesta lo anterior a través de un fragmento de la primera parte de El arpa y la sombra:

la condesa ponía buena cara a los vientos adversos con la fidelidad y cuidado de las apariencias que siempre la había caracterizado, observando lutos de parientes imaginarios, muertos en ciudades siempre distantes, para justificar el uso persistente de un par de vestidos negros, ya muy pasados de moda, y, por mostrarse lo menos posible al exterior, iba de madrugada a la iglesia de los Servitas, en compañía de su 
hijo menor, Giovanni Maria, para rogar a la Madonna Addolorata que aliviara estos atribulados estados del norte de sus agobios y calamidades. En suma: se llevaba la existencia de miseria altiva - escudos en puerta y chimeneas sin lumbre, cruz de Malta en el hombro pero vientre harto ayuno - que el joven Mastaï volvería a encontrar, al estudiar castellano, en las novelas de la picaresca española (228-29)

El papa Pío IX de la novela de Carpentier también tiene aspectos pícaros. Cuando estuvo en Chile, el futuro papa pudo comprobar que un "falso" factor de progreso anidaba allí, la peligrosa manía de pensar, los aires de la Revolución Francesa, un jacobinismo trasnochado que abría las mentes, y las hacía suyas. Corría 1824; no caía, por ello, de sorpresa. El liberalismo radical había comenzado a cebarse en las obedientes conciencias religiosas, sembrando el cisma teológico y la consigna rebelde. En Chile, unos jóvenes elegantes y descreídos, le habían dado a entender que pronto se restablecería la libertad de prensa y que existía la intención de secularizar el clero chileno:

Mastaï adoptó una táctica nueva ante quienes presumían de liberales en su presencia: táctica consistente en presumir de más liberal que los mismos liberales. Y, usando de estrategias aprendidas con los jesuitas, proclamaba que Voltaire y Rousseau habían sido hombres de un 
extraordinario talento - aunque él, eclesiástico, no puede compartir sus criterios -, recordando sin embargo, con sutil perfidia, que esos filósofos pertenecían a generaciones muy superadas por las actuales en sus ideas, y que, por lo mismo, era hora ya de ponerse al ritmo de la época, desechando textos, apolillados, llenos de conceptos históricos desmentidos por la realidad, haciéndose urgente la adopción de una "nueva filosofía ". (El arpa y la sombra 242)

Giovanni Maria Mastai - Ferretti, Pío IX, por su habilidad de manejarse con el pensamiento adverso, según el texto de Carpentier, ascendería a la posición de Sumo Pontífice de la Iglesia católica con el nombre de Pío IX y la reputación de hombre liberal y amigo del progreso.

El asombro del hombre europeo ante la naturaleza americana es una constante en la obra narrativa de Carpentier. En El arpa y la sombra encontramos este asombro en el personaje del joven Mastai cuando en su recorrido por Chile observa la magnificencia del paisaje americano:

Al lado de estos increíbles farallones erguidos sobre la tierra, de cimas extraviadas en las nubes - como inaccesibles - los Montes Dolomitas, por él conocidos, le parecieron montañas de paseo y adorno (era cierto que sólo hollada sus primeras estribaciones), revelándosele, de pronto, la desmesura de esta América que ya empezaba a 
hallar fabulosa a pesar de que sus hombres, a menudo, le parecían incultos, brutales y apocados, dentro del ámbito que poblaban. (238-39)

Mastai queda marcado por la experiencia americana. Acodado en la borda de barco que lo lleva de regreso a Europa (irónicamente en el texto de Carpentier el barco lleva por nombre "Colombia"), Mastai evoca las aventuras y peripecias del aquel accidentado viaje.

La primera parte de la novela, El arpa y la sombra nos aproxima al personaje histórico del papa Pío IX. Su idea de promover un proceso de beatificación a Colón es recogida, en el texto de Carpentier. El intento de beatificación del Almirante respondió a razones políticas: el Vaticano aspiraba a consolidar su poder en el Nuevo Mundo a la sombra de un símbolo unificador de la fe católica frente al avance del liberalismo anticlerical, al menos esa es la teoría de Carpentier en su novela:

Lo ideal, lo perfecto, para compactar la fe cristiana en el viejo y nuevo mundo, hallándose en ello un antídoto contra las venenosas ideas filosóficas que demasiados adeptos tenían en América, sería un santo de renombre ilimitado, un santo de una envergadura planetaria, incontrovertible, tan enorme que mucho más gigante que el legendario Coloso de Rodas, tuviese asentado en esta orilla del Continente y el otro en los finisterres europeos, abarcando con la mirada, por sobre 
el Atlántico, la extensión de ambos hemisferios. Un San

Cristóbal, Christophoros, Porteador de Cristo, conocido por todos, admirado por los pueblos, universal de sus obras, universal en su prestigio. $\mathrm{Y}$ de repente, como alumbrado por una iluminación interior, pensó Mastaï en el Gran Almirante de Fernando e Isabel. (El arpa y la sombra 248)

El tono satírico que subraya la narración convierte la narración en burla y en teatralidad grotesca la conducta del papa Pío IX. Este personaje sintetiza en sí, en el texto de Carpentier, las diferentes voces de biógrafos, dramaturgos e historiadores que crearon una visión hagiográfica de Colón.

\section{LA MANO}

La segunda parte de la novela se caracteriza por el estilo burlesco y la compone un largo monólogo de Cristóbal Colón mientras espera a su confesor momentos antes de morir. ${ }^{12}$ La novela se concentra en esta parte en el personaje de Colón y el descubrimiento de América. A manera de collage se sintetiza el diario de viajes y cartas del navegante, así como biografías escritas sobre él y diferentes puntos de vista del discurso historiográfico. Colón es protagonista y narrador de esta parte de la novela. El narrador protagonista realiza un relato retrospectivo de sus memorias momentos antes de morir. El relato del Almirante ofrece 
una visión alternativa de la visión hagiográfica y apologética sobre Colón de otros textos tradicionales. El Almirante se representa a sí mismo como un ser cegado por la lujuria y la ambición.

Toda la historia es narrada moviéndose del pasado hasta el momento presente en que el narrador protagonista va a morir y cierra la historia como se cierra un círculo. En este relato del Colón carpenteriano, sobreviven los aspectos del mundo maravilloso de la novela de caballerías y de la literatura de viaje, en parte porque el YO "colombino" utilizado por Carpentier, desde una perspectiva intertextual, es una síntesis de narrativas previas entre las que se encuentran fragmentos de discursos de textos autobiográficos de Colón, como memorias y diarios, y el discurso historiográfico de diferentes procedencias y a veces con planteamientos contradictorios. Aunque el relato monologado del Colón de Carpentier sea un pastiche intertextual de textos autobiográficos de Colón y de otros autores, prevalece en el mismo la intencionalidad del autor de desmontar la visión hagiográfica, mítica y apologética del protagonista de uno de los acontecimientos más importantes de la historia universal: el descubrimiento de América.

En El arpa y la sombra hay una reescritura irónica de los textos colombinos considerados textos fundacionales de la literatura hispanoamericana. La figura de Colón le interesa a Carpentier, entre otras cosas, por la importancia de éste como origen de la narrativa 
hispanoamericana. Carpentier en su teoría de lo real maravilloso se valió a menudo de los textos colombinos como discurso fundacional y legitimador de sus propias estéticas novomundistas. En El arpa y la sombra el Almirante, antes de morir, relee los borradores de sus textos. Por medio de esta relectura, se evocan fragmentos de los diarios de viaje y a la vez el personaje realiza una autocrítica, que está en concordancia con los criterios del discurso historiográfico desmitifador de la figura de Colón. Los diarios y cartas del Almirante se convierten entonces en un intertexto en esta novela de Carpentier.

La actitud autocrítica del Colón de Carpentier, al releer sus borradores, se puede encontrar en varios pasajes de la segunda parte de la novela. Veamos por ejemplo uno donde el Almirante nota que la palabra Oro es la más repetida en todos sus escritos:

Ahora que, ya rondando por la muerte, en espera de un confesor que harto tarda en llegar, repaso las hojas amarillas, todavía olientes a remotos salitres, del borrador de la Relación de mi Primer Viaje, me causa grima, remordimiento, vergüenza, ver la palabra ORO tantas veces en él escrito. (El arpa y la sombra 313)

y más tarde agrega:

Llego a indignarme ante mí mismo al ver, por ejemplo, que en día 24 de diciembre, en que hubiese debido meditar 
acerca del Divino Acontecimiento de la Natividad, estampo cinco veces la palabra ORO, en diez líneas que parecen sacadas de un grimorio de alquimista. (El arpa y la sombra 313)

Los comentarios autocríticos de Colón al releer los borradores de sus textos imponen una visión irónica respecto a la imagen del Almirante y a su diario de viajes. Además sirven de apoyo a la intención de EL arpa y la sombra de desmantelar la visión hagiográfica de Colón y mostrarnos a un hombre ambicioso de riquezas, cuya obsesión con encontrar oro se debía en parte a que ésta era la única manera de saldar las deudas obtenidas con la banca y la corona española para la realización de su viaje.

Esta visión desmitificadora de Colón que encontramos en la novela de Carpentier está en concordancia con la perspectiva de historiadores y críticos como Beatriz Pastor, quien afirma:

Dejando de lado la mitificación a que pueda haberse visto sometida la figura de Cristóbal Colón por una tradición crítica y biográfica bien intencionada pero no particularmente exacta, la lectura de los escritos del Almirante revela que éste no fue precisamente un soñador. Es indudable que éste poseía una imaginación notable, pues de otro modo no habría sido capaz de articular su proyecto ni de llevarlo a 
cabo. Pero el reconocerle esta capacidad no equivale a ignorar el hecho de que ésta no era, en el caso de Colón, de carácter desinteresado y poético, sino que estaba subordinada al propósito de logro de unos intereses materiales y sociales muy concretos. (Discursos narrativos de la conquista: Mitificación y emergencia 46)

El Colón de El arpa y la sombra sin duda no representa a la figura que determinados escritores e historiadores apologistas crearon en sus textos.

El Cristóbal Colón que se presenta en El arpa y la sombra no es un misionero cristiano o un portador de cultura, sino un personaje ambicioso, perverso; un judío converso con pretensiones de grandeza, sediento de oro, ansioso de inmortalidad, que llegó a proponer la creación de una empresa que consistiría en capturar negros, a través de la lonja de esclavos de Sevilla, para transportarlos a América.

La novela de Carpentier no se limita a reproducir la historia; evidentemente, el autor consulta e incorpora numerosa información tomada de la misma, pero dándole su propia interpretación y aprovechando siempre que puede los vacíos dejados por el discurso historiográfico. Carpentier imagina y recrea libremente lo que pudo ocurrir en determinado período del que nos ha llegado poca información. Por esto, en parte, la novela es un collage de fragmentos de textos 
históricos y otros con el fin de adecuarlos a las exigencias narrativas y de evitar contradicciones estridentes entre historia y ficción. Por ejemplo en la novela se narra el viaje de Colón a Islandia. ${ }^{13}$ Viaje que ha sido motivo de controversia entre historiadores. Menéndez Pidal reconoce que el viaje de Colón a Islandia es una de las pocas cosas que no pueden discutirse cuando se enfoca su vida. Henri Vignaud, sin embargo, difiere de Menéndez Pidal. Carpentier en su novela da por cierto el viaje. Según El arpa y la sombra, Colón supo en Islandia de la existencia de tierras si se navegaba hacia el Oeste:

...estos hombres cubiertos de pieles, rompiendo las nieblas a toque de buxines, habían navegado más al Oeste y más al Oeste aún, descubriendo islas, tierras ignoradas, [...] Pero eso no era todo. Yendo siempre hacia el Oeste, más al Oeste, y aún más al Oeste, un hijo del marino pelirrojo, llamado Leif-el-de- la-buena- suerte, alcanza una inmensa tierra a la que pone el nombre de "Tierras de Selvas". Allí, abunda el salmón; crecen la baya y la mora; inmensos son los árboles, y - portento increíble en tal latitud - la yerba no desvanece en el invierno. (268)

La novela de Carpentier recoge la tesis de que Colón sabía de la existencia de tierras si se navegaba rumbo al Oeste, donde ya los vikingos habían estado con anterioridad. La información la obtuvo, el 
Colón carpenteriano, de un judío llamado Maestre Jacobo. Al parecer este personaje es una creación de Carpentier. Según Leonardo Acosta, en su trabajo "El almirante según don Alejo", por los datos que se nos dan de él, podría ser una fusión de tres personajes históricos: del Maese Jacobo de Mallorca, un judío catalán, piloto insigne en su tiempo; del maestre Josephe, otro judío de la escuela náutica portuguesa y contemporáneo de Colón, y del maestre Rodrigo, uno de los maestros del Almirante en el oficio de navegar.

Ahora cabe uno preguntarse, si es válida la teoría de que Colón, en un viaje a Islandia, supo de la existencia de tierras navegando rumbo al oeste, por qué Colón nunca reveló la existencia de esas tierras que ya habían sido descubiertas por "los hombres rubios del Norte". El Colón de Carpentier, en el recuento de sus memorias, lo explica de la manera siguiente:

Sé a ciencia cierta que hay grande, poblada y rica tierra al Oeste; sé que navegando hacia el Oeste iría a lo seguro. Pero si viene a saberse mi certeza de que navegando hacia el Oeste iré a lo seguro por lo sabido en la Tierra del Hielo, quedaría muy menguado el mérito de mi empresa. ( El arpa y la sombra 274 )

La ambición del Almirante se hace aliada del secreto, por lo tanto, el gran navegante calla la verdad. 
La novela recrea con humor carnavalesco, y de acuerdo a las fuentes de la historiografía tradicional cómo Colón fue por diferentes cortes europeas sin importarle, según el discurso desmitificador de Carpentier, qué reino se beneficiara del mismo. "En cuanto a la gloria lograda por mi empresa, lo mismo me daba que ante el mundo se adornara este u otro reino, con tal de que se me cumpliese en cuanto a honores personales y cabal participación de los beneficios logrados" (EI arpa y la sombra 276). Carpentier recurre a lo carnavalesco para presentarnos a un Colón que recorre Europa buscando financiamiento para su empresa:

Armaba mi teatro ante duques y altezas, financistas, frailes y ricos hombres, clérigos y banqueros, grandes de aquí, grandes de allá, alzaba la cortina de palabras, y al punto aparecía, en deslumbrante desfile, el gran antruejo del Oro, el Diamante, las Perlas, y sobre todo, de las Especias.(El arpa y la sombra 276)

Este "mi Retablo de Maravillas" (285), como lo llama el Colón carpenteriano, es otro recurso intertextual de la novela que en este caso nos remite a través del anacronismo a Cervantes.

La existencia de este tinglado es un ejemplo de cómo a veces la realidad supera a la ficción. El "tinglado de las maravillas" existió de verdad. Lo pasearon Cristóbal y su hermano Bartolomé por diferentes 
partes de Europa. Consistía en un hábil mapamundi donde se señalaban las tierras conocidas y las que todavía quedaban por conocer. Con artificio de feriante, como acompañado de una de esas carretas cíngaras decoradas de vivas tonalidades, Bartolomé Colón se presentó en la corte inglesa de Londres, ante Enrique VII; desplegó una hermosa carta de navegación, por él mismo diseñada, que se anunciaba con la siguiente inscripción de retablo de cristobita:

Esta sugerente, completa y sabia pintura te mostrará los límites más fértiles de cuantas tierras desees conocer, como suscriben Estrabón, Ptolomeo, Plinio e Isidoro: cada uno con su propio razonamiento, sin embargo. Viene adornada, además con aquella zona tórrida [Cabo Verde y la Mina] recientemente surcada por naves españolas [esto es portuguesas] antes desconocidas del mundo, y que por fin es ahora bastante conocida de muchos. Londres, 13 de febrero de 1488. (Hernando Colón 86)

A continuación, entraba, el mono y jugaba con el mapa. En la novela el Colón de Carpentier explica con un argot callejero y vulgar sin precedentes en otras novelas del mismo autor, como se fracasó ante las corte inglesa "porque esos ingleses de mierda nada saben de cosas marinas" (El arpa y la sombra 281). El tono humorístico, con numerosos diálogos de bajo estilo burlesco permanece a lo largo de toda obra, 
contrastando con el tono hiperintelectual de otros pasajes de la novela. Este Colón de Carpentier llega a convertirse en trágico bufón que poco a poco va presentando su verdadero rostro y desenmascarando al Colón mitificado, entre bromas y verdades.

La novela de Carpentier menciona también varios acontecimientos históricos, como la capitulación de Granada, la expulsión de los judíos de España, los preparativos de las campañas africanas, el gran recibimiento de los Reyes Católicos a Colón, a la vuelta del primer viaje de éste, en Barcelona, entre otros. La nueva novela histórica, usando formulaciones estéticas nuevas, rescata el imaginario popular e incorpora algunas formas arcaicas como la leyenda. La existencia de una atracción amorosa entre Colón e Isabel la Católica siempre ha sido parte del imaginario popular y fue recogido en diferentes leyendas. El arpa y la sombra recrea esa relación amorosa con el humor grotesco que caracteriza a la novela histórica hispanoamericana en su corriente más actual. La historiografía oficial reconoce la existencia de una segunda audiencia real concedida por los monarcas Isabel y Fernando a Colón en el año 1491. A partir de este acontecimiento histórico el autor del Arpa y la sombra imagina libremente un romance entre el Almirante y la soberana española.

De aquella audiencia, el Colón de Carpentier, en su monólogo, recuerda la belleza de los ojos verdiazules, lo sonrosado del semblante y aguda inteligencia de la reina castellana. Colón, menciona las muchas 
infidelidades del rey Fernando y recuerda, refiriéndose a Isabel, que "la persona a quien hablaba de mi gran proyecto era - y esto lo sabían todos -quien gobernaba de verdad" (El arpa y la sombra 284). Ante ella continúa Colón "desplegué una vez más, mi Retablo de Maravillas, mi aleluya de geografías deslumbrantes" (285). En ese relato de sus memorias, el Colón carpenteriano dice:

Y, aquel día. Movido por una audacia de la que me hubiese creído incapaz, pronuncié palabras, como dichas por otro palabras que no repetiré en mi confesión- que me hicieron salir de las estancias reales cuando empezaba a sonar las dianas de los campamentos. (287)

Con el humor propio del discurso narrativo más actual, el Colón del Arpa y la sombra hablando consigo mismo y siendo nosotros, los lectores, los únicos testigos, cuenta sobre la reina Isabel:

En las noches de su intimidad. Columba- así la llamaba yo cuando estábamos a solas - me prometía tres carabelas, diez carabelas, todas las carabelas que quisiera: pero, en cuanto amanecía se esfumaban las carabelas, y quedaba yo solo, andando con las luces del alba, camino de mi casa, viendo caer los mástiles y velámenes que se hubiesen erguido triunfalmente en mis visiones de grandeza, vueltas, 
en la claridad del día, a la vaporosa irrealidad de los sueños que jamás se fijan en imágenes tangibles... (287) En la novela de Carpentier se explica con un lenguaje humorístico e irreverente como Colón, cansado de las promesas de Isabel, al fin consigue de ella el préstamo necesario para llevar a cabo su proyecto. La escena parece más propia de una película de Almodóvar que de los textos a que estábamos acostumbrados por Carpentier:

Repentinamente montado en iracundia, desde lo alto de mi boca le clamé que, aunque cortés y sumiso en mi comportamiento para con ella, atento a que mi púrpura, aún invisible, envuelve siempre un cuerpo de reina, me sentía igual que cualquier monarca y tanto montaba yo, sin tiara enjoyada, pero aureolado por el nimbo de mi Gran Idea, como montaban las coronas de Castilla y de Aragón. “¡Marrano!” - me gritó ella: “¡No eres sino marrano!” “¡Marrano soy!” - grité a mi vez: “iy nadie puede saberlo más mejor que tú, que me conoces en lo que soy y en lo que fui!" (288)

Según El arpa y la sombra, poco después, Isabel, y de acuerdo con la leyenda, le informaba a Colón que había dado sus joyas al banquero Santángel en garantía para que le fuera concedido un millón de maravedís para su proyecto marítimo. 
En esta novela de Carpentier existe una estética del espectáculo que carnavaliza la historia. La presencia del carnaval en la literatura se manifiesta a través de motivos como la máscara y el grotesco. A través de personajes que se definen por sus máscaras y por su actuación, así como por los roles e imágenes circenses que parodian la historia y la transforman en un espectáculo grotesco, se establece una imagen del mundo como teatro y de la historia como el gran espectáculo. Predomina en El arpa y la sombra la máscara como distintivo de la simulación y la falsedad atribuida a Colón. El conjunto de escenas de feria y circo organizadas por manipulaciones del Almirante describen a Colón como un gran farsante, un hombre en permanente actuación. En la novela de Carpentier la concepción de la máscara representa la falsedad de la imagen de Colón y la historia como espectáculo. El Almirante, en el texto de Carpentier, se autodefine en su monólogo como un farsante y como tal actúa:

...cuando me asomo al laberinto de mi pasado en esta hora última, me asombro ante mi natural vocación de farsante, de animador de antruejos, de armador de ilusiones, a manera de los saltabancos que en Italia, de feria en feria. [...] Ilevan sus comedias, pantomimas y mascaradas. Fui trujamán de retablo, al pasear de trono en trono mi Retablo de Maravillas. Fui protagonista de sacra reppresentazione al representar 
para los españoles que conmigo venían, el gran auto de la Toma de Posesión de Islas que ni se daban ni por enteradas. Fui ordenador magnífico de la Gran Parada de Barcelona primer gran espectáculo de Indias Occidentales, con hombres auténticos, presentados ante los públicos de Europa. (El arpa y la sombra 341)

Colón en su recuento evoca sus roles como astrólogo e inquisidor que tuvo que representar en el gran teatro del "descubrimiento" de América: Y, mudando el disfraz, fui Astrólogo y Milagrero en aquella playa de Jamaica donde nos hallábamos en la mayor miseria, sin alimentos, enfermos, y rodeados, para colmo, por habitantes hostiles, listos a asaltarnos.[...] Y fui Inquisidor, amenazante y terrible[...] aquel día en que, en las costas de Cuba, hice preguntar a los marinos si alguna duda abrigaban de que esa gran tierra fuese Tierra Firme, nación continental, comarca avanzada de las vastas Indias cuyos regalo [...]se esperaba de mí en España. E hice proclamar, por voz de notario, que quien pusiese en tela de juicio que esta tierra de Cuba fuese un continente pagará una multa de diez mil maravedís. [...] Yo-Inquisidor consiguió lo que quería. Todos los españoles [...] me juraron y volvieron a jurar [...] Yo 
necesitaba que Cuba fuese continente y cien veces clamaron

que Cuba era continente... (El arpa y la sombra 341-42)

La novela de Carpentier está Ilena de pasajes que ejemplifican el carácter teatral y carnavalesco del texto. Veamos otros ejemplos de cómo recuerda el Colón de Carpentier su regreso a España después de su primer viaje a América.

Según relata Colón en su monólogo, Sevilla lo recibió "con albricias y alegrías, estandarte y campanas, cumplidos de altura y admiración de balcones" (317) y los reyes le invitaron a la Corte, la cual se hallaba en esos momentos en Barcelona:

Y llegóme el día. Día de fiesta en toda Barcelona. Como feriante que entra en castillo trayendo grande espectáculo, entré yo en el palacio donde se me aguardaba, seguido de $\mathrm{mi}$ gran compañía de Retablo de las Maravillas de Indias primer espectáculo de tal género presentado en el gran teatro del universo - compañía que quedó en una recamara, formando en un orden determinado desde hacía varios días, habiendo yo mismo dirigido los ensayos y colocado los personajes. (319-20)

La descripción de Colón, en el texto de Carpentier, de su presentación ante las Cortes españolas en Barcelona, hecho histórico según varias fuentes historiográficas, evoca el teatro y el circo. Lo circense de la 
escena se acentúa con la inclusión de animales y de los indios

disfrazados con bragas cosidas con hilos de oro para representar el gran espectáculo: la gran función teatral de Colón en Barcelona.

En esta segunda parte de la novela, el personaje de Colón se desdobla; el desdoblamiento es debido a los roles y máscaras que ha asumido en su vida. Se contrapone un Colón histórico y uno privado al contrastar los diarios de viajes con la versión "verdadera" y nunca revelada de sus experiencias. Cuando el Colón de Carpentier relee su propio diario, afirma:

Y la constancia de tales trampas está aquí, en estos borradores de mis relaciones de viajes, que tengo bajo la almohada, y que ahora saco con mi mano temblorosa asustada de sí misma - para releer lo que, en estos postreros momentos, tengo por un vasto Repertorio de Embustes. (EI arpa y la sombra 303)

Esta polaridad entre las dos imágenes de Colón converge en la última parte de la novela, cuando la vida del Almirante es juzgada como parte del proceso de beatificación que se le sigue.

\section{LA SOMBRA}

Esta tercera y última parte de la novela resulta ser un auténtico carnaval historiográfico y literario en el que asistimos al debate en torno 
a la propuesta de beatificación de Colón. ${ }^{14}$ El esperpéntico proceso que se le sigue al Almirante, en el texto de Carpentier, puede situarse, en el tiempo histórico real, en el siglo XIX, durante el pontificado de León XIII (1878-1903) y a cuatro siglos de distancia de los sucesos juzgados. En realidad, es un proceso fuera del tiempo en el que, por una parte el autor, recrea el proceso con plena libertad, mezclando personajes de épocas distintas y reproduce, a la vez, con fidelidad, sus opiniones respecto a Colón.

Diferentes personajes históricos, entre los que están autores conocidos y también personajes literarios, se presentan en el Vaticano convocados por la Sacra Congregación de Ritos, para emitir su opinión como testigos de cargo en este juicio a Colón. Participan en el juicio Bartolomé de las Casas, León Bloy, José Baldi, Víctor Hugo, Jules Verne, el Obispo de Chiapas y Alfonse Lamartine. Otros personajes históricos, aunque no aparecen en el juicio, son mencionados en esta última parte de la novela, formando parte del gran carnaval histórico y literario que ocasiona el proceso de Colón en el Vaticano. Entre los personajes mencionados están: el conde Roselly de Lorgues, Karl Marx, Fernando VII, Luis XVI, Juana de Arco, Rodrigo de Triana, Voltaire, Washington Irving, entre otros.

Se establece una gran controversia sobre el tema; algunos defienden y otros atacan al Almirante. Convergen en esta parte la 
polaridad de las dos imágenes de Colón, el mitificado y el ser humano. Una vez expuesta la candidatura a la beatificación, son escuchadas las diferentes opiniones sobre el caso. La candidatura finalmente es rechazada en base a dos acusaciones contundentes: las relaciones "ilícitas" del Almirante con la cordobesa Beatriz Arana, madre de Fernando Colón; y su intento de establecer un comercio de esclavos en el Nuevo Mundo, hecho del que da testimonio el polémico obispo de Chiapas.

Predomina en esta última parte tan carnavalesca de la novela, que contiene algunas de las páginas más divertidas de toda la novelística de Carpentier, un tono de humor irreverente Por ejemplo, el autor, al traer el tema de la controversia de dónde descansan los restos de Colón, usa en su novela un lenguaje coloquial vulgar y callejero, no acostumbrado en sus obras anteriores. Veamos las palabras del joven seminarista que se adiestraba en los métodos de clasificación de huesos de la Lipsonoteca del Vaticano:

Y empiezan los jodedores de siempre a decir que si ésos no son los de Colón I sino los de Colón II, y que si los de Colón I siguen en Cuba, y una cura venezolano publica un sonado folleto acabando de enredar el pleito, y ahí se arma una que ni la del Filioque... [...] Esto es una Lipsonoteca seria, [...] Y en cuanto a mí, no voy a pararme entre dos ataúdes para 
jugar el juego de: Tin -Marín- DedóPingüe-Cúcara-Mácara-

Títere-Fue. (El arpa y la sombra 355-56)

La farsa, lo satírico, la burla y la teatralidad grotesca se hacen más marcadas en esta parte de la novela.

El tono burlesco acentuado convierte el proceso de beatificación en teatralidad pura. José Baldi, postulador de la candidatura, genovés muy apreciado por la curia romana por sus frecuentes donativos y obras de caridad, en el texto de Carpentier realiza un enfático resumen de la vida de Colón defendiendo la visión hagiográfica del Almirante en el proceso. Para ello cita al escritor francés León Bloy: "Pienso en Moisés, porque Colón es revelador de la Creación, reparte el mundo entre los reyes de la tierra, habla de Dios en la Tempestad, y los resultados de sus plegarias son el patrimonio de todo el género humano" (358-59). Al terminar Baldi su defensa de Colón, el tomo irónico y carnavalesco del juicio se acentúa: “¡Olé! - exclama el Abogado del Diablo, con palmaditas de jaleador en tablado flamenco: ¡Olé y Olé! El debate sobre la beatificación de Colón, alcanza en el texto de Carpentier, un tono de espectáculo festivo donde el lector puede saltar de la risa a la carcajada, como por ejemplo, cuando Fray Bartolomé de Las Casas es Ilamado a comparecer como testigo de cargo, ante lo cual exclama la sombra de Colón: “Ahora sí que me jodí” (363). 
Esta tercera parte de la novela, subdividida a su vez en dos, culmina con el diálogo entre Colón y otro famoso almirante genovés, Andrea Doria, en la plaza de San Pedro. Al final, queda sola la sombra de Colón: "quedó el Hombre-condenado-a-ser-un-hombre-como-los demás" (377). La sombra mira las columnatas de Bernini, de la Basílica de San Pedro, donde la columnata frontal oculta perfectamente las otras tres, pareciendo una sola ${ }^{15}$, dice el texto de Carpentier que la sombra de Colón pensó: "Juegos de apariencias, como fueron, para mí, las Indias Occidentales" (377). Palabras que nos Ilevan a pensar en las múltiples formas de hacer historia en lo que atañe a aspectos, tales como la manipulación concreta de la dimensión temporal, donde sitúan los fenómenos estudiados; el manejo específico de las categorías de verdad y objetividad; la utilización de diversas escalas de observación de los hechos investigados y las diferentes técnicas de exposición. Desde la perspectiva de nuestro presente postmoderno, ambiguo y pluridimesional, la historia puede ser contada como sugieren los espejos en la obra de Borges, en infinitas posibilidades, hasta la de perderse en un laberinto de espejos, que es quedar atrapado en el infinito.

En conclusión, podemos decir que El arpa y la sombra es un texto autorreflexivo, metaliterario e irreverente de su propia teleología que se adscribe a la corriente más actual de la nueva novela histórica. La última novela de Carpentier es un texto postmoderno que se aleja de la 
narrativa anterior en general y de la del propio autor. Asistimos a la crisis de los metarrelatos, legitimadores de instituciones, prácticas sociales e ideologías propias de la cultura postmoderna, donde los grandes temas del pasado como el héroe, los grandes peligros, los viajes y los elevados propósitos, ya no tienen cabida.

El texto de Carpentier es una síntesis paródica que recrea los aspectos más conocidos y la vez más controvertidos, de la personalidad de Colón, recogidos en diferentes textos que mantienen un diálogo paródico con la tradición literaria e historiográfica a la que pertenece. Como afirma Santiago Juan - Navarro: "El concepto borgeano del texto como palimpsesto es llevado aquí hasta sus últimas consecuencias al proponer el autor cubano una visión de la historia que no sólo interroga las visiones hegemónicas, sino que cuestiona y problematiza aquellas expresadas anteriormente por Carpentier “. (El arpa y la sombra”. n. pag.) En El arpa y la sombra, podemos encontrar varios de los rasgos paradigmáticos de lo que Seymour Menton y Fernando Aínsa califican como nueva novela histórica hispanoamericana; ejemplifica lo que otros teóricos han denominado metaficción historiográfica y ficción postmodernista.

En esta novela, se cuestionan las pretensiones de objetividad del discurso histórico; es un texto que se enmarca dentro de la ficción postmodernita para la cual las verdades históricas no existen. La novela 
de Carpentier, coetánea de la filosofía de la historia de Hayden White, sintoniza con las nuevas corrientes en la filosofía de la historia cuando descubre los mecanismos de la verdad histórica como artificio cultural sujeto al discurso del poder. La desmitificación de Colón, llevada acabo por el texto de Carpentier, es tan cuestionable como la de aquellos textos que pretenden dar una visión hagiográfica y apologética del Almirante. Tanto en la novela de Carpentier como en las biografías más conocidas, existe una maniobra autorial del archivo, mediante la que se manifiesta un marcado escepticismo ante el valor de la verdad en la representación histórica. 


\section{NOTAS}

' Juan José Barrrientos considera que la renovación de la nueva novela histórica comienza con El mundo alucinante de Reinaldo Arenas y no con El reino de este mundo de Alejo Carpentier como plantea Seymour Menton. (Ver Barrientos 23)

${ }^{2}$ Cristóbal Colón ha tenido varios biógrafos. El primero fue su hijo Fernando. Entre otras de sus biógrafos se encuentran George Washington Irving (Life and Voyages of Christopher Columbus, 1828); Jacob Wassermann (Christoph Kolumbus, 1929) y Salvador de Madariaga (Vida del muy magnífico señor Cristóbal Colón, 1940). También algunos dramaturgos han llevado su vida a la escena, como Lope de Vega en una comedia de 1604 y Paul Claudel en una ópera de 1930.

${ }^{3}$ El anacronismo tiene en este caso un efecto metaléptico al recordarnos que después de todo, estamos leyendo una novela.

${ }^{4}$ En El arpa y la sombra el personaje de Colón es presentado desde la perspectiva de otros personajes, desde afuera. Carpentier toma la perspectiva del propio protagonista.

${ }^{5}$ Vease. Edward Elton Hales. Pio Nono; a study in European politics and religion in the nineteenth century; Titus Heydenreich "'Il viaggio in cile (1823-25) di Giovanni Maria Mastai (1846 - 78, Papa Pío IX): Conseguenze politiche e letterarie" y Giacomo Martina. Pio IX.

${ }^{6}$ Ver Kenneth L. Woodward, La fabricación de los santos, para los datos relacionados con el Papa Mastai y su polémico pontificado. K. L. Woodward es periodista norteamericano, responsable de las páginas de teología del semanario Newsweek. El mayor especialista mundial en la vida y la obra de Pío IX es el padre jesuita Giacomo Martina, profesor de la Universidad Gregorina de Roma; lleva editados tres volúmenes biográficos al respecto, de 1974 a 1986.

${ }^{7}$ La biografía de Cristóbal Colón escrita por su hijo Fernando Colón es escasa en cuanto a datos sobre la infancia de Colón. El original de esta biografía se perdió y no fue editada hasta 1571 en Venecia por Luis Colón (hijo de Fernando Colón), en idioma italiano, treinta y dos años después de terminada.

${ }^{8}$ Los escritores franceses Paul Claudel y León Bloy decidieron dignificar en tal grado al personaje de Cristóbal Colón que terminaron por inventárselo de principio a fin. Propusieron una figura mística y mítica, digna de alcanzar la gloria de los santos; un emisario de los cielos, que abrió para Occidente, no una nueva ruta comercial, sino un escondido e inmenso mundo de almas necesitadas de salvación. Colón fue ante todo, según ellos, el Cristos ferens, el portador del Cristo.

${ }^{9}$ Carpentier intenta presentar a Colón de carne y hueso. El autor rechaza la posibilidad de un carácter providencial en los descubrimientos, procurando explicarlo de manera materialista.

${ }^{10}$ El Diario Mastai Breve relazione del viaggio fatto al Chile dal canonico Giovanni Maria Ferretti di Senigallia sólo se publicó después de su muerte siendo incluido en la biografía de Alberto Serafín. Vease también Heydenreich 161-169. 
"Ver Miguel Batllori y Pedro de Laturia; Giuseppe Sallusti y Avelino Ignacio Gómez Ferreira.

${ }^{12}$ El uso de monólogos en personajes históricos de novelas históricas no es algo novedoso. La influencia de Yo, Claudio (1934) de Robert Graves es evidente en novelas con monólogos extensos de personajes históricos como sucede en El arpa y la sombra (1979); Vigilia del Almirante (1992), de Roa Bastos; Noticias del Imperio (1987), de Fernando del Pasos; y El largo atardecer del caminante (1993), de Abel Posse.

${ }^{13}$ En Ficción - historia. La nueva novela hispanoamericana. Juan José Barrientos plantea que:

Alejo Carpentier no sólo da por hecho el viaje a Islandia que se le atribuye a Colón, pero que ha sido muy discutido [...] sino que adopta una tesis "nórdica" que resulta escandalosa en los países latinos, donde siempre se ha resentido los esfuerzos por acreditar la saga de Leif Erison como intento de reescribir la historia para quitarles la gloria del descubrimiento de América; incluso en los Estados Unidos, se escucharon millones de protestas cuando la universidad de Yale publicó un mapa de Vinladia en 1965. (28)

${ }^{14}$ La propuesta de canonización representa la tendencia hagiográfica, dada en la primera parte de la novela como posibilidad que puede o no cumplirse pero que no halla oponentes hasta la tercera parte de la narración, donde se ficcionaliza la pluralidad del juicio de la historiografía.

${ }^{15}$ La referencia a las columnatas de Bermini puede ser considerada como una metáfora del eje semántico de esta novela de Carpentier donde el juego entre realidad y ficción resulta un desafío a todo el que intente buscar la verdad histórica. El arpa y la sombra, al igual que otras novelas históricas hispanoamericanas, en su corriente más actual trasciende la idea de la historia unidireccional. La novela de Carpentier incorpora las múltiples voces que han interpretado y enjuiciado a Colón. 


\section{Sexto capítulo: Los perros del paraíso}

\section{LOS PERROS DEL PARAISO (1987): UNA NOVELA NOVOMUNDISTA}

La novela de Abel Posee Los perros del paraíso se aproxima a la historia con un discurso novomundista que recrea, desde una perspectiva contemporánea, el descubrimiento de las Antillas y a su personaje protagonista, Cristóbal Colón. El Almirante es visto desde una óptica que se aleja del discurso tradicional y mitificador. ${ }^{\prime}$ En esta novela existe una notoria inversión del contenido de las categorías y los estereotipos consagrados por la historia oficial. Existe en Los perros del paraíso un replanteamiento de la dicotomía "civilización-barbarie", de la figura de los Reyes Católicos y de la imagen del Colón Conquistador.

En Los perros del paraíso la civilización está sobre todo en el plano espiritual, en la población indígena, y la barbarie, en la conducta brutal de los españoles. Por otra parte, en esta novela los Reyes Católicos se transforman en una pareja de terribles adolescentes, cuya presunta condición sobrehumana (insinuada en una nota al pie de página) propone una nueva "angeología" del descubrimiento de América y el renacimiento en España. ${ }^{2}$

El personaje de Isabel de Castilla en particular, en Los perros del paraíso, se aleja por completo del icono devoto canonizado por determinados historiadores para alcanzar la plenitud sensual de una 
deidad pagana. A su vez, a Colón, en la novela, se le contempla en una faceta poco explorada por la historiografía tradicional: su empresa, desde la óptica de esta novela, deja de ser puramente mundana, para convertirse en la búsqueda del Paraíso Terrenal emprendida por un probable descendiente del profeta Isaías.

Los perros del paraíso ejemplifica la corriente más actual de la nueva novela histórica hispanoamericana. En esta novela Posse:

reitera igualmente sus rasgos estilísticos más destacados y maduros, en particular los que lo definen como un escritor barroco dentro de la concepción arriba delineada del barroco hispanoamericano que Severo Sarduy y otros prefieren Ilamar 'neobarroco'. (Márquez Rodríguez 57)

Posee, en Los perros del paraíso, desmonta el tiempo y rearma las piezas en formas nuevas e interesantes.

El autor arranca desde los tiempos de Enrique IV de Castilla. "el Impotente", y desde la lucha por la sucesión entre la "Beltraneja" e Isabel, hermana del rey, la futura reina "Católica" para llegar a Colón y su empresa del descubrimiento. La mezcla de personajes y épocas inicialmente desorienta, pero pronto el juego del autor atrae al lector a una trama en la que se mezclan acontecimientos y épocas muy diversas, que llegan hasta la historia más reciente, de Europa y América: de Hitler a Franco y las dictaduras hispanoamericanas, de Pedro Mártir a 
Torquemada, de críticos conocidos como Todorov a personajes de distintos momentos y capas sociales, en un acercamiento que divierte al lector, aclarándole implícitamente, a través de la alusión, el comentario directo y la comparación, sucesos del pasado y presente.

Aparentemente la historia es seguida con fidelidad desde el punto de vista cronológico, pero el narrador la transforma, la hiperboliza; es otra realidad, totalmente nueva, a veces alucinada. Posse hace de Colón, de acuerdo con la versión de que era judío, el perseguidor de un territorio de salvación para su gente, la "Nueva Jerusalén". La ironía en esta novela es un arma eficaz: a la maravilla la sustituye la violencia y a pesar de ello el personaje de Colón mantiene su halo de soñador y de iluso, o de loco que cree haber alcanzado el jardín famoso de donde Adán y Eva fueron expulsados. En la novela de Posee, el amor, el sarcasmo, la ironía, el humor se alternan y se conjugan.

Al igual que Carpentier en El arpa y la sombra, Posse sigue los hechos históricos para darnos su versión de los acontecimientos y de la personalidad de Colón. Los perros del paraíso tiene en común con El arpa y la sobra la misma intención desmitificadora del personaje histórico de Cristóbal Colón. ${ }^{3}$ En ambas novelas, el Almirante fue un arribista que, lejos de ideales nobles y humanitarios, sólo se movía por sus propios intereses y los de su familia. ${ }^{4}$ Posse reinventa la historia del 
descubrimiento de América creando una versión hiperbólica, carnavalesca y abundante en anacronismos y referencias textuales.

Hay en el texto de Posse una integración de información proveniente de las fuentes tradicionales de la historiografía y de otras que son producto de la imaginación del autor, que en conjunto forman una narración que imita paródicamente a un texto de historia. En Los perros del paraíso, Posse nos ofrece una visión de los últimos cuatro decenios del siglo XV que disiente de la oficial. En la novela de Posse, la reconstrucción de los acontecimientos históricos se halla imbuida de una perspectiva contemporánea, dotada con frecuencia de un fuerte matiz paródico que hace resaltar, por contraste, la angustia existencial de Colón.

En una entrevista, Abel Posse, da su propia interpretación sobre la novela:

Yo interpreto Los perros del paraíso como una guerra de dioses, entre el dios judeo-cristiano, que trae el catolicismo imperial, no el cristianismo, y el dios americano que tiene otro código, una relación distinta con el cosmos. Se produce ahí una ruptura, una noción de ser muy distinta, la que trae Europa y la que vive América Latina. De este choque no hubo una solución. No hubo una síntesis final y al no haber una síntesis, al seguir ese conflicto, América Latina se transforma 
en este continente enfermo que vivimos nosotros.

("Conversación con Abel Posse" 109)

El tono general de la novela es ágil y jocoso y presenta un tratamiento caricaturesco de los personajes.

A través de la novela y con intención lúdica, Posee asocia libremente elementos del pasado con elementos del presente cuya relación es tangencial. Así, a Colón se le atribuye el habla de los argentinos, nos explica el autor en una nota a pie de página, el Almirante, "como la mayoría de los argentinos, era un italiano que había aprendido español. Su idioma era necesariamente bastardo" (65). EL Salve Regina y el Te Deum celebrados en el Nuevo Mundo se transforman en protorrumbas, y el "coro de seminaristas, educados por los timbales de hueso y los areitos de los ángeles" (215-16), en verdaderas "Sonora matancera" (216). La princesa Anaconda se halla abrigada por una breve tanga de plumas de quetzal "un lujo que entre los taínos equivalía al tapado de visón de los europeos" (216). La intención lúdica y el vaivén cronológico es una constante a lo largo de toda la novela.

La representación de escenas o personajes por medio de comparaciones extremas otorgan al subtexto histórico un carácter subversivo que cuestiona el discurso histórico, además de ofrecer nuevas posibilidades que divergen del discurso tradicional. En una entrevista, 
Abel Posse se refiere en líneas generales a la metodología empleada en alguna de sus novelas:

Tergiverso y creo fantasías en base a personajes históricos, pero en base a hechos ciertos o que pudieran metamorfosearse en una incertidumbre. Es decir, que hay una serie de juegos elípticos, sucesivos, de arabescos, o sea, el barroco... EL barroco está consubstanciado con la descripción histórica de América. La historia era, además, la historia oficial de América. La escribieron los conquistadores, los clérigos y después los penosos académicos fascistas. Hay que decirlo. En España no hubo revisionismo histórico... Somos nosotros, los americanos, los que hemos formado la conciencia del continente. (García Pinto 500)

Esta novela constituye un texto provocador en cuya compleja estructura se entrecruzan el humor, la poesía y la tragedia. Los perros del paraíso es una obra ambiciosa de relevante elaboración intelectual. Esta novela nos ofrece una reinterpretación novel del momento histórico en que se sientan las bases de la sociedad americana.

Los perros del paraíso es una novela donde abunda la recreación de personalidades históricas. Recrea entre otros a Enrique IV, conocido como "el Impotente", a su polémica hija la Beltraneja, al cardenal Borja, futuro Papa Alejandro VI. También encontramos personalidades históricas 
anacrónicas ligadas al pensamiento filosófico europeo, como Karl Marx, Nietzsche, Swedenborg. Alcanzan relevancia protagónica en la novela de Posse en primer lugar Cristóbal Colón, Isabel de Castilla y, en cierto grado, su esposo Fernando de Aragón.

Algunos de los personajes de la novela son sumamente sugerentes, como Ulrico Nietz que evoca a Nietzsche y el lansquenete Swedenborg, al genio místico del mismo nombre tratado por Borges, que veía su influencia en William Blake y a través de éste, en Bernard Shaw. En la novela, Ulrico Nietz es un marginal, como lo son los indios, un marginal filosófico, pero que tiene un elemento revulsivo extraordinario. Los elementos culturales europeos, como Swedenborg y Nietz/Nietzsche, son utilizados en el texto para enriquecer el juego literario y evitar el arquetipo.

El elemento histórico en Los perros del paraíso se entremezcla profundamente con el drama cultural europeo. EL texto de Posse trata de ser objetivo cuando sugiere que a América no llegó solamente el catolicismo como religión imperial, sino que llegaron también la voluntad del héroe y del conquistador. La presencia de un hombre como Nietzsche significa en la novela la llegada a América del otro foco de la realidad europea. Es la oposición a la noción judeo-cristiana y metafísica. El viaje del descubrimiento de América tuvo un resultado significativo y perturbador por las consecuencias y las crisis que crea. Es 
un viaje que entrelaza lo real, el misterio, la ideología y la religión. La llegada de los españoles a América fue motivo de perturbación. Los nativos vieron llegar a hombres con una piel de blancura irritante, barbas rojizas o ennegrecidas, coraza, sombrero; pero lo que más les debió haber sorprendido es la insistencia en tanta ropa. Los indígenas no podían saber que la ropa, más que vestidura era investidura. Los indígenas, por el contrario, andaban desnudos:

Los recién llegados desconocían esa saludable naturalidad. En Europa no se veían cuerpos desnudos desde la conversión de Constantino al cristianismo. Desde entonces, la túnica vaporosa, los baños de vapor y las playas quedaban deshabitados. La desnudez ingresa como signo evidente del pecado. Pasa a ser característica de brujas y endemoniados. Sólo en los burdeles medievales podría tener cabida semejante aberración. (Posse "El alucinante viaje" 199)

En Los perros del paraíso, los conquistadores son recibidos por princesas danzantes, en quienes la desnudez es una aproximación a lo sagrado. El erotismo de las aborígenes, en el texto de Posse, es seducción estética, forma perfecta de belleza similar más bien a una imagen renacentista.

En esta novela la sexualidad aborigen es presentada como espontánea, inocente; y a la vez, de sentido ritual. La sexualidad de los 
españoles, por el contrario, es presentada como manifestación de una libido reprimida cuya eclosión grotesca y violenta desconcierta a los indígenas, y está relacionada, por un lado con la animalidad, y por el otro con el "pecado" del goce, que encuentra su placer en el sadomasoquismo.

Abel Posse, en Los perros del paraíso, a través de un hábil manejo del 'aquí' y del ‘ahora' enriquecido por anacronías, hipérboles, metáforas y símbolos, con un vocabulario chispeante, humorístico, trasgresor, plagado de neologismos ingeniosos e irónicos, logra la ruptura del espacio - temporal. ${ }^{5}$ La obra nos presenta dos mundos, dos concepciones que entran en movimiento; son piezas que se escapan de las coordenadas hasta quedar superpuestas, y cuando se recomponen al final de la novela, el discurso ha reelaborado una visión diferente en la que lo histórico-documental se convierte en una reescritura crítica de la historia del "Descubrimiento".

La novela de Posse en su vaivén cronológico lleva a cabo una síntesis del pasado, presente y futuro. Por ejemplo, algunos personajes del texto, como Roldán, reflejan el prototipo del futuro militar golpista hispanoamericano:

Fue un verdadero golpe de Estado. Roldán tuvo que ser nombrado Alcalde Mayor, pero en realidad tenía todas las riendas del poder, era el hombre fuerte: se había adueñado de las llaves de la armería y de la pólvora. Ésta, en 
escandalosa apropiación pretoriana, será el delito de acción continuada más largo que conoce América. (229)

Lo que sucede después del golpe es la síntesis de lo que sucedería posteriormente en América Latina.

EL Paraíso Terrenal, del Colón de Posse, se convierte en zona proveedora de materias primas, mano de obras baratas y apetecido lugar turístico:

Empezaban años de frenesí empresarial. Sobraba mano de obra y comenzaba a saberse emplear la materia prima local. Por ejemplo, los cigarros de hoja, de uso ritual, se impusieron rápidamente en Europa. EL doctor Nicot, basado en el informe científico del milanés Francesco Montani, universalizó su uso, demostrando que la nicotina, aparte del placer, curaba el cáncer. (231)

Los estudios de marketing fueron minuciosos. Se logró que quien tomaba yerba mate, como los tupí-guaraníes, terminasen bebiendo café etiópico en tazas de Talavera. [...] El cacao originario, la "delicia de los dioses", retornó por el Atlántico en barritas de chocolate suizo, según el método inventado por el señor Uhlich, un relojero fracasado. (232) 
Importaron los primeros métodos para conservar la escarcha. Se podían hacer refrescos de leche de coco y cócteles de cacao al ron. Las horchatas y achilatas se vendían caras. A todos les parecía haber entrado la furia del fresco. (En la industria del frío, como en tantos otros ramos, los iberos pronto serían desplazados por piratas rubios que desembarcaban sus aparatos con nocturnidad y los vendían a precio de dumping. En este tráfico se destacaron William Westinghouse y Jan Phillips, grandes mayoristas de temperatura.) (233)

En la peculiar visión anacrónica de Posse, Colón regresa a España prisionero y en su camino al puerto ve en los edificios anuncios como "Agencia Cook", "United Fruit Co." Las piedras talladas de la puerta del paraíso terminan siendo enviadas a la sección "Arqueología Amerindia" de un museo en Bruselas. ${ }^{6}$

Los perros del paraíso centrada en la figura de Colón y el descubrimiento de las Antillas invierte el contenido de las categorías y los estereotipos creados por la historiografía oficial. La novela replantea la dicotomía "civilización y barbarie" y la imagen de las figuras protagonistas del descubrimiento. Esta novela desmonta el tiempo y rearma las piezas en forma novedosa al mezclar personajes y épocas diversas creando una trama que atrae al lector. La historia es 
transformada, hiperbolizada creando una realidad nueva y alucinante.

Posse, con su discurso novomundista y carnavalesco, se aleja de la visión eurocéntrica del discurso histórico oficial y reinventa la historia del descubrimiento desde una perspectiva crítica y autorreferencial.

\section{PROCEDIMIENTOS PARA LA REESCRITURA DE LA HISTORIA}

La novela está dividida en cuatro partes que coinciden con cuatro ciclos caracterizados simbólicamente por los cuatros elementos naturales: "El aire”, "El fuego", "El agua” y "La tierra”, según aparecen mencionados en El libro de los linajes del Chilám Balam de Chumayel:

Todo está terminado.

La madre dice levantando al recién nacido: ¡Ah chiquito! ¡Ah criatura!

Ahora venido eres al mundo a padecer:

¡sufre, padece, calla!

Del Oriente vinieron los barbudos, los falsos mensajeros de la señal, los extranjeros, los hombres rubicundos. 
¡Ay! Entristezcamos porque vinieron, porque llegaron los grandes amontonadores de piedras, de vigas para construir, con fuego en el extremo de sus brazos. ¡Entristezcamos porque llegaron! ¡Nuestros dioses ya no se volverán más! Este "dios verdadero que viene del cielo" sólo de pecado hablará, sólo de pecado será su enseñanza. Inhumanos sus soldados crueles sus mastines bravos.

Solamente por el tiempo loco, Por los locos sacerdotes de sotana negra Fue que entró en nosotros el cristianismo. Fue el principio de nuestra miseria, el principio del tributo, el principio de la limosna.

Estamos seguros. Hemos hecho la experiencia. Ha comenzado la era del Sol en Movimiento que sigue a las edades del Aire, el 
Fuego, el Agua, y la Tierra. Este es

el comienzo de la edad final, nació

el germen de la destrucción y de la

muerte. EL Sol en Movimiento, el Sol

en la tierra, eso pasará."

(Libro de los Linajes del Chilám Balam de Chumayel.)

EL poema, un testimonio altamente crítico del hombre blanco, contradice el discurso de la conquista. Los poetas nativos se duelen de las nefastas consecuencias de la llegada de los españoles, demostrándose así capaces de enfrentar la realidad de su desdicha.

Los cuatro ciclos caracterizados simbólicamente por los cuatro elementos naturales: "El aire", "EL fuego", "El agua” y "La tierra", estructuran el peregrinaje de Colón, introduciéndose en el primer ciclo al Colón soñador que resuelve romper con las tradiciones familiares, y concluyendo en el cuarto ciclo con su regreso a España en cadenas, incomprendido y vituperado, bajo la supervisón de Bobadilla. No es hasta la conclusión de la novela que nos enteramos que la división de los sucesos europeos ha seguido una clasificación que corresponde a la idea de los cuatro soles sostenida por los mayas, según lo revela el poema del Chilám Balam.

"El aire" se inicia con un panorama general de la crisis del mundo medieval, el surgimiento del renacentista y la aparición de la secta de los 
buscadores del Paraíso. Pasa luego a una serie de visiones alteradas de tres macrocosmos. El primero es de la península ibérica, con localización en Castilla, Aragón y Andalucía, en el cual se mueven Enrique IV, Juana la Beltraneja, Isabel y Fernando, alrededor de quienes giran otros personajes menores, cuyas acciones demuestran las intrigas y los problemas sucesorios de los reinos hispánicos. EL segundo macrocosmos es el de la península itálica, cuyos centros de interés están en Génova y en Roma, donde viven Cristóbal Colón y sus padres, y Alejandro VI (Rodrigo Borja) y sus hijos, respectivamente. El tercer macrocosmos es el de Las Indias, centrado en México, adonde arriba un enviado del mundo hispánico.

Los dos primeros macrocosmos forman una alianza para la conquista del "Paraíso Terrenal", o América, mientras que en éste se inician conversaciones tendentes a la conquista de Europa, o el mundo de los "blanquísimos", que terminan fracasando. Esta disposición de fábula continúa en "El fuego" pero no en "El agua" donde se presenta el viaje del Almirante y su escala en las Islas Canarias. El viaje o los viajes de Colón concluyen en la cuarta y última etapa: "La Tierra", donde el Almirante entra en contacto con el Nuevo Mundo, localización espacio-temporal que se completa casi diez años después cuando Colón es capturado y llevado prisionero a España. 
En Los perros del Paraíso, la personalidad de Colón y los preparativos del viaje presentan un fresco de los acontecimientos de la época. El deliberado entrecruzamiento del acontecer europeo e indoamericano y las constantes interpolaciones del narrador omnisciente, que opina desde un marco contemporáneo, subvierten la historia oficial y crean una visión por momentos paródica del descubrimiento y de las circunstancias relacionadas con el hecho.

La voz narrativa en la novela de Posse, juzga, compara y comenta, reflejando una visión totalizadora de la civilización occidental. La voz narradora no escamotea hacer comentarios. Veamos un ejemplo, en referencia a Isabel de Castilla; el texto de Posse dice:

(Isabel tenía diecinueve años y su cuerpo, como lo afirman todos los cronistas, "era de ampulosas y perfectas caderas". Más que el de una teen-ager, su cuerpo era el de una rumbera de treintidós. Muy parecido, en efecto, al de la Blanquita Amaro en su apogeo). (47)

Este tipo de comentario de la voz narrativa es muy común en la novela de Posse.

La comparación de la reina Isabel de Castilla, con la vedette cubana, es parte del discurso irreverente que caracteriza a la nueva novela histórica. La comparación ayuda a desmitificar la imagen de Isabel como mujer adusta de porte señorial. También aparecen en la 
novela de Posse comentarios intercalados por la voz narrativa, a manera de nota a pie de página. Estos comentarios, no sólo parafrasean el discurso historiográfico tradicional, sino que señalan el carácter relativo de toda información procedente del archivo histórico.

EL narrador va más lejos subrayando la generalizada carencia de documentación con que se caracteriza gran parte el discurso histórico: "muy poco de lo importante queda por escrito, de aquí la falsedad esencial de los historiadores" (109). Dado el tono empleado en la narración, aunque la crítica sobre la historia aparente estar dirigida a censurar una metodología deficiente, el objetivo del autor es mucho más abarcador.

El narrador justifica su versión de la historia apoyándose en los "vacíos" del discurso historiográfico y supuestas falsedades e inexactitudes de los textos tradicionales. El narrador descalifica, de esta manera, a ciertas fuentes tradicionales, como la biografía de Colón escrita por su hijo Fernando y las crónicas del fraile Bartolomé de Las Casas:

(sólo hay Historia de lo grandilocuente, lo visible, de actos que terminan en catedrales y desfiles; por eso es tan banal el sentido de Historia que se construyó para consumo oficial.) (66) 
Después, en el pupitre inauguró con su reconocida caligrafía el Diario Secreto que su hijo bastardo, Hernando, dañaría irremediablemente y del cual el padre Las Casas recogería algunas cenizas, sólo pasajes de sensatez. (141)

Al atacar abiertamente la veracidad histórica, el novelista establece el punto de partida para ofrecernos una visión más amplia de la historia.

La aceleración del tiempo es una de las técnicas narrativas utilizada en la novela, sintetizando sucesos que tomaron años en ocurrir. Los cuatro viajes de Colón, por ejemplo, en la novela de Posse se sintetizan en uno solo. ${ }^{7}$ En la narración de este único viaje se produce una ruptura del orden espacial temporal e histórico:

El Almirante pronto comprendió que su propósito significaba una ruptura flagrante del orden espacio-temporal establecido. Que la apariencia del mundo quedaría seriamente inferida.

Era un hecho nuevo y surgían nuevas circunstancias.

El horizonte espacial-histórico fue quebrado por la proa de la Santa María. [...]Por la rajadura del velo espacio - temporal, empezaron a deslizarse seres, naves, escenas humanas que el Almirante tuvo, como visionario que era, que aceptar sin tratar de buscar explicaciones que excederían las modestas posibilidades de la época. (175) 
En lugar de las tres carabelas del primer viaje de Colón, que recogen los textos historiográficos, en la novela de Posse aparece todas las otras naves en las que se realizaron los viajes posteriores del Almirante.

Existe en el texto una aceleración del tiempo histórico que conlleva al uso del anacronismo. Por ejemplo, cerca de la flota española en que iba Colón, pasaban otras naves de las primeras décadas de un siglo futuro:

El Almirante las estudió con cuidado. Son grandes barcos sin velamen que transportan gran cantidad de humanos y de cosas. Algunas tienen chimeneas enormes, de metal, y dejan una estela de humo curiosamente pareja, como si no fuese un incendio.

Una de ellas, la Rex, pasó dejando un velo de música feliz. [...]Música sincopada (el Almirante no puede saber que se trata de la rumba "El manisero" tocada por Lecuona. [...]Pero la frecuencia con que aparecen estas naves caídas del futuro es realmente inquietante. [...] Así vio el bajel Mayflower cargado de puritanos terribles que iban rumbo a la Vinland, [...] Tanto hacia el norte, hacia Novaia Gorod, como hacia el Plata, van naves sombrías cargadas de emigrantes sicilianos, genoveses, extremeños, irlandeses. Carne de labor, de 
mestizajes y bastardía, movida por modestos sueños subsistenciales. (177)

Esta estrategia de condensar sucesos históricos no es una novedad dentro de la nueva novela histórica hispanoamericana. Carlos Fuentes, por ejemplo, la utiliza en su novela Terra nostra, donde se narran durante el reinado de Felipe II sucesos históricos que realmente ocurrieron durante los reinados de otros monarcas españoles.

Como parte de estos procedimientos de síntesis, la novela de Posse, incorpora personajes históricos que pertenecen a épocas futuras. Por ejemplo, aparecen cuatro lansquenetes que viajan a América con los españoles, que resultan como ya hemos vistos anteriormente, personalidades históricas (de siglos posteriores al descubrimiento) del pensamiento y la cultura europea: Ulrico Nietz, Swedenborg, Marx y Todorov, entre otros.

De manera inversa, el texto de Posse, también nos remite al pasado remoto: al origen. El protagonista de Los perros del paraíso, como el protagonista de Los pasos perdidos de Carpentier, encuentra un espacio originario y armónico, donde no existe el tiempo. ${ }^{8}$ Ambas obras nos remiten a un espacio mítico y a un tiempo que está más allá del tiempo histórico. El Almirante de Posse ya una vez en el Nuevo Mundo, que él creyó el Paraíso Terrenal, dice: 
La red del tiempo aquí se desteje. Casi nada significa ya hablar de día, de noche, de semana, de año... [...] Estamos en otro espacio. ¡Por fin estamos dentro del mundo, en el mundo y no ante la realidad, como eternos mirones tristes con nuestro metro de sastres! (242-43)

Colón se cree en el Paraíso y establece su hogar bajo el Árbol de la Vida. La desnudez obligatoria es decretada y se prohíbe producir y acumular materiales con fines comerciales.

La intertextualidad explícita, una de las características de la nueva novela histórica hispanoamericana, abunda en Los perros del paraíso. El narrador de esta novela alude a El arpa y la sombra de Alejo Carpentier. También hay una alusión al cuento "EL sur". Entre otro ejemplo de intertextualidad está la escena en que Isabel tuvo que conquistar al león anciano agarrándolo por las sienes, lo que nos remite al Poema del Cid y a Don Quijote de la Mancha:

el león, nieto del que tuvo el rey Juan, está echado a todo lo largo del umbral. Con ojos entrecerrados controla los rítmicos ronquidos reales. [...] Entonces Isabel se adelanta y grita:

- ¡Fuera!

Pero es inútil. Le aplica un decidido soplamocos. Enfurecida, se le prende de las crines y le muerde una oreja. Después de 
un breve silencio amenazado, el león cede a la decisión, no a la escasa fuerza de la niña. (18)

La música también se intertextualiza en la novela cuando suena una rumba de Ernesto Lecuona o se menciona a "Siboney", título de una canción del mismo compositor cubano que Posse utiliza para nombrar a una princesa caribeña. Existe referencias a otras canciones del repertorio de canciones caribeñas como "Perfidia" y "Vereda Tropical". Otro aspecto del anacronismo intertextual en la novela es la presencia, fácilmente identificable de Marx y Nietzsche, al igual que de Cervantes y Descartes o las citas de fragmentos de versos de precolombinos

Existen en la novela varios recursos relacionados con la intertextualidad, tales como lo irónico, lo sarcástico, lo paródico y lo carnavalesco. La funcionalidad de estos recursos reside en: 1) sugerir la fusión de mito e historia y presentar una visión satírica del pasado; 2) apoyar la verosimilitud de lo narrado, después de desarticular el tiempo y recomponerlo de una manera novedosa; 3) incorporar lo fantástico; y, por último, 4) permitir una reelaboración de signos reveladores de la identidad americana. El narrador de la novela es también lector e intérprete de otros textos como, por ejemplo, los códices indígenas que se incorporan como fuente histórica sobre los sucesos incas y aztecas: 
Huamán Collo y el tecuhtli de Tlatelolco a punta de sandalia avanzaban por el papel delicadamente pintado del Codex Vaticanus $C$ que narra el banquete de despedida en la incomparable Technotitlán. (57)

En esta novela la intertextualidad estalla, pronunciada a menudo como parodia burlesca, pero también como visionaria anticipación de una escritura por venir, y como transfiguración poética de viejos textos y antiguas tradiciones en hallazgos insólitos.

Otra relación intertextual evidente en Los perros del paraíso es la que existe con algunas novelas de Carpentier, fundamentalmente entre $E I$ arpa y la sombra y la segunda parte ("El fuego"), de la novela de Posse. En esta parte se narra, con un discurso marcado por el erotismo, el encuentro de Colón y la reina Isabel:

Ante ella, la reina, su carne se retrajo sin posibilidad de movimiento alguno. (Por eso yerra el gran Alejo Carpentier cuando supone una unión sexual, completa y libre, entre el Navegante y la Soberana. La noble voluntad democratizadora lleva a Carpentier a ese excusable error. Pero es absolutamente irreal. La intimidación del plebeyo fue total en el aspecto físico. Total, en cambio, fue su descaro metafísico y así alcanzó la liberación del panorgasmo). (1 19-20) 
La cita anterior no sólo demuestra una relación de intertextualidad explícita con El arpa y la sombra sino que también revela la relación paródica existente entre este tipo de novelas.

Otras relaciones intertextuales se establecen entre la novela de Posee y otras de Carpentier. Por ejemplo, en El siglo de las luces se trae al Caribe en el barco de Víctor Hugues, la guillotina, símbolo de terror e instrumento de la opresión revolucionaria; en Los perros de paraíso se trae también al Caribe en el barco de Colón la "cruz-horca" donde "culminará el via crucis de la Semana Santa y durante el año, y con frecuencia, los sacrificios sin prestigio de ladrones, asesinos y subversivos" (134).

Los perros del paraíso parodia las crónicas sobre el descubrimiento y la conquista de América a través de dos técnicas. Una de ellas consiste en que el narrador relata con el mismo estilo del género situaciones absurdas e hiperbólicas. Cada uno de los capítulos de la novela comienza, al igual que los manuales historiográficos, con un esquema cronológico que resume los acontecimientos históricos de supuesta relevancia del período histórico que trata ese capítulo. Están relatados en tercera persona con una voz narrativa que intenta simular la "objetividad" de los textos históricos. Se alude de esta manera a la posible falsificación de la historia oficial. 
La otra técnica usada por Posse es la parodia del género historiográfico. La novela recurre como la historiografía tradicional al uso de citas. En Los perros del paraíso abundan las citas absurdas. El narrador de la novela nos remite a documentos que, en el caso de la novela de Posse, son productos de la imaginación del autor. Se establece, entonces, un contraste entre la irrelevancia de lo narrado y la exactitud con la cual el discurso tradicional historiográfico registraría estos sucesos. En la novela también encontramos la utilización de fuentes históricas reales con citas inventadas por el autor. Veamos algunos ejemplos:

Pedro Mártir, el cronista, anotó que, terminada la arenga, Roldán guiñó el ojo canallescamente a los labriegos, todavía indecisos de dar apoyo al grupo revolucionario, y les dijo textualmente: "¡Apoyadnos! En vez de la azada os encontraréis con las manos llenas de dulces tetitas. Trabajará la indiada, vosotros reposaréis (Dácadas, Libro V, cap. V). (228)

El cronista Oviedo escribió así del perro Becerillo destacando sus cualidades moralizadoras: "Era ferocísimo lebrel defensor de la fe católica y de la moral sexual, descuartizó más de doscientos indios por idólatras, sodomitas y por delitos 
abominables, habiéndose vuelto con los años muy goloso de carne humana". (237-38)

Una nota del autor al pie de la página relacionada con la cita anterior dice:

Fernández de Oviedo, Historia General y Natural de Indias, tomo X. También merecieron justas biografías el hijo del anterior, Leoncico y Bruto, Amadis, Calisto y Amigo, de la pluma de Juan José Arrom, Herrera, Chavelevoix, etc. EL coronel Roldán organizó una comisión de canes, guardiana de la moralidad pública y la censura. En esto también fue un precursor. (238)

En los textos historiográficos tradicionales las citas ayudan a la acreditación del discurso y nos remiten a fuentes de reconocida "autoridad", otorgando al relato verosimilitud y confiabilidad. En Los perros del paraíso los documentos o citas a los cuales se refieren, al ser inventados, subvierten el carácter fidedigno del texto historiográfico.

La estructura dialógica o dialogismo es parte de los conceptos bajtinianos. La actitud revisionista de la historia está totalmente armonizada con el carácter irónico, dialógico y carnavalesco de Los perros de paraíso. En esta novela son muchas las voces que se oyen y resultan a veces polémicas y contradictorias pero contribuyen a formar el discurso de denuncia contra el poder implícito en la novela. El carácter 
dialógico se manifiesta en el mismo título, puesto que los perros son los guardianes de la entrada al Infierno mientras Colón identifica a la nueva tierra con el Paraíso Terrenal. Para los amerindios, la llegada de Colón representa la conversión del Paraíso en el Infierno. Posse utiliza el mismo lente dialógico para ver a todos los personajes y sucesos de la novela. Por ejemplo, evita idealizar a los aztecas y a los incas en la escena donde representantes de los dos imperios se encuentran en Tlatelolco para decidir si se conquistaba a Europa.

La misma actitud dialógica revelada por Posse en su plasmación de las civilizaciones precolombinas también se observa en la caracterización poco mimética de Colón. Posse no retrata a Colón como héroe mítico. Para reforzar el retrato dialógico de Colón con el humor postmoderno, caracteriza al Almirante en términos ambiguos. Por otra parte, de acuerdo con el carácter dialógico de la novela, el catolicismo fanático de Isabel no concuerda con su lujuria descontrolada. Además de la creación de personajes ambivalentes, el carácter dialógico de Los perros del paraíso también se revela en la afirmación, y a la vez, la subversión de la historicidad. Posse desconfía de los historiadores y esto le lleva a ofrecer una distorsión grotesca y paródica de la visión historiográfica oficial.

La novela de Posse, como es característico en la nueva histórica hispanoamericana en su corriente más actual, abunda en anacronismos que ayudan a la distorsión del discurso histórico tradicional, como por 
ejemplo, en la petición de fondos al rey para el Congreso de Cultura Hispánica de 1940, o cuando el Mayflower se cruza con el barco de Colón rumbo a América. También cuando personajes anacrónicos como Cervantes, Marx, Descartes acompañan a Colón en el viaje.

Otro ejemplo de anacronismo ocurre cuando Colón vuelve a la costa, detenido; con cadenas y grilletes observa anuncios comerciales como el de United Fruit Co. Alexis Márquez Rodríguez plantea que: "Posse vuelve en esta novela sobre la estructura del contrapunto, ya no sólo entre tiempos cronológicamente distintos, sino también entre tiempos que transcurren simultánea y paralelamente" (Abel Posse 57). El vaivén cronológico permite que el pasado y el futuro se superpongan y entrecrucen en textos que dialogan como el discurso de Roldán, guardia de Bartolomé Colón, que se destaca como incipiente amenaza del militarismo en los siglos XIX y XX. En lo que respecta a los viajes de Colón, el relato salta del primer viaje al tercero, para enfocar en la llegada a la desembocadura del Orinoco, lugar que el Almirante cree es la entrada del Paraíso. Convencido de que ha llegado al fin de su búsqueda, Colón se desnuda y procede a buscar el árbol bíblico.

La ironía es un característica clave de Los perros del paraíso. La lectura de esta novela requiere un lector dispuesto a aceptar el tono irónico e hiperbólico del texto, sin el cual no podrá comprender la desmitificación de los tópicos históricos. La lectura histórica nos lleva a 
una relectura de la historia tradicional, que introduce elementos totalmente inaceptables por la historia oficial, como, por ejemplo, el cuerpo y la sexualidad. El elemento farsesco, irónico y cómico de estilo narrativo de Posse es una de las claves para desacralizar en sus novelas, donde se crean figuras o situaciones impostadas, exageradas y caricaturescas de los rasgos verdaderos de una personalidad. Al respecto, el autor plantea:

El elemento caricaturesco funciona con ese fin de acceder con más facilidad a la historia de América, donde la sexualidad en particular estuvo excluida, porque todas las versiones de la historia de América son versiones españolas prácticamente ya en la esfera de la religión católica. [...] [y] quise demostrar que en América aparte del genocidio, se produjo una gigantesca violación. Esa violación es el origen de la América actual. Para acceder a esa idea, yo tenía que intraponer un ingrediente sexual en toda la aventura de transferencia de Europa hacia América. (Spiller 110)

Es cierto que existe todo un elemento erótico en esa interpretación de la historia, pero en realidad todo el mestizaje de América viene de una descomunal y fantástica violación.

Resulta también irónica la división, en la novela de Posse, del período histórico que va del casamiento de los Reyes Católicos al arresto 
de Colón, de acuerdo con una clasificación creada por la cultura conquistada. La función de la ironía es fundamental en Los perros del paraíso, por cuanto le sirve al novelista para articular su imagen de la historia. Difiriendo de la posición historiográfica que enfatiza los hechos, el autor sintetiza los efectos, en Los Perros del Paraíso, de la siguiente manera: "sólo hay Historia de lo grandilocuente, lo visible, de actos que terminan en catedrales y desfiles; por eso es tan banal el sentido de Historia que se construyó para consumo oficial." (66) Al Indagar las causas que promovieron los hechos históricos por medio de alternativas, con frecuencia disparatadas, la historia, despojada de su solemnidad, adquiere nuevos significados y matices.

\section{DISCURSO DESACRALIZADOR DE COLÓN Y DEMÁS PROTAGONISTAS DE LA CONQUISTA}

La novela de Posse tiene un proyecto de desmitificación del personaje de Cristóbal Colón. En la imagen del almirante conviven lo sublime y lo ridículo. Las argucias que utiliza para hacerse oír en la corte son tan disparatadas como jocosas. Acomplejado por su origen plebeyo, incurre en actitudes ridículas ante una Isabel danzante que lo fascina, o se comporta con afectación remilgada en la mesa de Beatriz de Bobadilla. Las descripciones físicas del Colón conquistador son por lo general rotundamente antiheroicas, desalentadoras, y lo vinculan más con Don Quijote que con las ilustres imágenes oficiales. 
La imagen de Colón en Los perros del paraíso es ambigua. Por un lado, el texto lo presenta como una arribista, sin ideales nobles y humanitarios, movido sólo por sus propios intereses y los de su familia. Por otro, se le presenta como un místico guiado por la idea de encontrar el Paraíso Terrenal. ${ }^{9}$ Una vez encontrado el Paraíso el Colón de Posse adopta una postura de pasividad cómplice. Este Colón:

en efecto, hamacado bajo una ceiba - que tiene por centro del Paraíso Terrenal -, ni siquiera asiste en persona a la imposición forzada del sistema mercantilista europeo, metáfora elemental de sus múltiples ausencias descubridoras respecto del campo de colonización del Caribe español. Como Verne diría, fueron los compañeros de Colón quienes fustigaron a los indios a espaldas suyas. (Usable González 258).

Además, como parte de su ambigüedad, el Colón de Los perros del paraíso pierde su racionalidad europea y se convierte en el primer mestizo:

Resultaba evidente que el Almirante había sufrido una mutación ya probablemente sin retorno. La conciencia racional, característica de los "hombres del espíritu" de Occidente, lo había abandonado. 
Sin saberlo [...] se había transformado en el primer sudamericano integral. Era el primer mestizo y no había surgido de la unión carnal de dos razas distintas. Un mestizaje sin ombligo, como Adán. (243)

Los perros del paraíso, al recrear la personalidad de Colón, le concede una individualidad que lo humaniza, al establecer el personaje una apasionada búsqueda por tierras desconocidas dentro de un plano místico-existencial.

El énfasis en la faceta mística de Colón, en la novela de Posse, sirve tal vez para mostrarnos la otra cara, la que no fue, de la Conquista, como redescubrimiento del paraíso perdido:

Hoy no caben dudas sobre la demora que padeció Colón antes de ingresar en el centro de la galaxia dextrógira del poder: tanto las ambiciones de la Corona como la de los agentes de las trasnacionales, le parecían frívolas, menores, previsible avidez humana. Reiteraciones poco novedosas. Él, en cambio, descendiente de Isaías, como se sabía, sólo buscaba la mutación esencial, la única: el retorno al Paraíso, al lugar sin muerte. (Los perros del paraíso 109)

Como antes otras veces, se sintió distante de los motivos simples - apenas imperiales, salvacionistas o comerciales - 
con que otros impulsaban la empresa de Indias, fuesen reyes, gerentes o judíos amenazados de hoguera.

Su soledad era grande. A nadie podía comunicar su secretísima - inefable - misión: buscar la apertura oceánica que permitiría el paso del iniciado a la inalcanzada - ¡perdida! - dimensión del Paraíso Terrenal.

Sabía que aquellas tierras mancilladas por la debilidad de Adán y la perfidia de su hembra permanecían en un punto del planeta que algunos iniciados habían ubicado. (Los perros del paraíso 130-31)

EL Colón de Posse se ve a sí mismo como instrumento de la voluntad divina y se considera guiado y protegido por Dios en sus acciones más diversas. Por eso a medida que la Santa María va surcando el mar, aproximándose al Nuevo Mundo, el Almirante va penetrando en un nuevo espacio no sólo físico, sino también temporal que le permite obtener una visión de lo que vendrá. "naves caídas del futuro" (177), "sin velamen que transportan gran cantidad de humanos y de cosas" (176). Presiente que se halla ante algo incomprensible, y, así lo acepta.

La ambigüedad de Colón, en Los perros del paraíso, se evidencia también, cuando analizamos que junto a la faceta mística del Almirante se presenta de manera grotesca e hiperbolizada el erotismo y la sensualidad de Colón como parte del discurso carnavalesco de Posse. En 
esta novela Colón cuelga a su esposa portuguesa por los tobillos y recorre con su lengua "amplios territorios de aquella piel de buena familia". Muerta Felipa, Colón se enamora de la judía Beatriz, "movido por una sana animalidad". Otro ejemplo de erotismo hiperbolizado es el que se establece en su relación con Beatriz de Bobadila, en la escala que hacen las naves en Islas Canarias. ${ }^{10}$ En la novela, Beatriz de Bobadilla de quien "[s]e decía era sabia en la dosificación de las drogas y en otras artes prohibidas" (152), se sintió impulsada a abandonar su costumbre de sadismo, inclinándose a disfrutar dominada, frente a la potencia sexual de Colón.

El Colón de Posse tiene también cierto grado de argentinización, lo cual ocurre a su vez con otros personajes, tales como el golpista y caudillo Roldán, que pudiera interpretarse como una metáfora de una Argentina/América que nació del choque de culturas, que le quita la razón. Abel Posse dice:

Yo jugué con Colón y, en cierta medida, Colón me pareció que era argentino. Porque él no era español, ni era absolutamente judío, como dicen, o por lo menos él, de religión, se declaraba católico. Era un personaje intermedio. Era el hombre que llega a América y que trae todas las contradicciones de ese continente, pero, al mismo tiempo, como era un marginal, podía adaptarse también a la 
compresión de América, podía interpretar y tener una cierta flexibilidad mayor que los otros frente al indígena. No hay que olvidarse que él vivió en una dimensión religiosa, metafísica, por lo menos yo lo presento así en la novela, un poco en broma lo tomo, pero es verdad que Colón tenía venas de mística. (Spiller 109)

En la novela de Posse, Colón es el único que se enfrenta al nuevo mundo con tolerancia. Se adentra tanto dentro de una fascinación por el supuesto paraíso que se vuelve loco. Colón sintetiza en la novela varios tiempos, de la misma manera que la narración lo hace. El fin de Colón, como el de todos los conquistadores de Posse, es de cierto modo el sacrificio. El Colón histórico tiene la dignidad ambigua del chivo expiatorio. Primero, es inmolado porque estorbaba en el nuevo orden social que quería establecerse; después sería exaltado hasta la sacralización por el discurso historiográfico oficial como el héroe y descubridor de América.

Isabel de Castilla, por obvias razones, es el personaje secundario de mayor importancia de Los perros del paraíso." Isabel aparece en la novela de jovencita, antes de ascender al trono de Castilla. La futura reina es representada en la novela como una joven precoz, no sólo diestra en intrigas palaciegas, sino también poseída por un erotismo extrema que contradice su tradicional representación histórica: 
La inminencia del amor turgía la carne de la princesa-niña. Días exaltados, turbulentos. Todo aire se transformaba en brisa caliente al aproximársele. Ni el viento frío de septiembre, que ya soplaba, la calmaba. Buscaba serenarse echándose a galopar salvajemente por los peñascales. Reventó tres caballos en diez días. Dice la crónica que empezó a emitir un olor potente - pero no repulsivo, por cierto - de felina en celo. (Los perros del paraíso 45) EL erotismo genera en Isabel audacia y energías sobrehumanas que le permitirán, no sólo tomar las riendas del gobierno en difíciles circunstancias sino también guiar a Castilla hasta el nacimiento de la España imperial.

En una evidente parodia de las autoritarias exégesis científicas en esta novela, se explica la exuberante sexualidad de Isabel. El texto de Posse con cierto eclecticismo conceptual contrapone la óptica psicoanalítica a la visión del materialismo histórico, lo cual contribuye a crear un efecto burlesco. Isabel sublima su compulsión sexual y "Freudianamente buscó una ideología para encauzar tanto deseo" (47), nos dice el autor, transformado "aquella compulsión sexual en una cruzada nacional y popular" (47) que la impelen a proclamar su programa de gobierno: 
Habló de un mundo sin pederastas, prestamistas ni comuneros destructivos. Prometió guerra a la inflación. Dijo que España debía alzarse sobre las rodillas en vez de vivir arrastrándose. Habló de pan, de trabajo, de grandeza.

Estuvo, adecuadamente demagógica: los pueblos, como las sirvientas, sólo quieren promesas para poder entregarse sin remordimientos.

Los cronistas no retienen el texto de aquella proclama; como siempre captan lo fácil. (47)

Las palabras y conceptos de la arenga revelan características del discurso del poder universalmente reconocibles; discursos semejantes se han pronunciado desde el comienzo de la historia con resultados tangibles.

Dentro de la inversión de la historia oficial que promueve la nueva novela histórica hispanoamericana actúan los recursos paródicos que desprestigian o matizan con humor las figuras heroicas. En Los perros del paraíso la única exenta es la reina Isabel, siempre consecuente con una grandeza que se enmarca en la exaltación general de la "sacralidad" femenina, profundamente ligada con el "descubrimiento de los cuerpos", que constituye la cara dionisiaca de la Conquista.

La relación entre la reina Isabel y Colón ha sido tema de interés de los historiadores y forma parte de leyendas de variados matices que han llegado hasta el presente. En Los perros del paraíso la relación entre ellos 
es la que corresponde entre soberana y súbdito, en contraposición con la relación de amantes representada en El arpa y la sombra. ${ }^{12}$ La novela de Posse traza la dimensión que alcanzan sus vidas públicas y las frustraciones personales que les ocasiona llevar a cabo las empresas proyectadas. EL Renacimiento, con su vitalidad y énfasis en el individuo promueve una nueva era que se encuadra magníficamente con los objetivos de Isabel y Cristóbal Colón.

El discurso erótico es parte del carácter carnavalesco de la nueva novela histórica hispanoamericana en su corriente más actual y de esta novela en particular. Consecuente con lo planteado, en esta novela, se narra el encuentro de Colón e Isabel de Castilla:

No tuvo dudas: era ella. Cayó de rodillas. No podía controlar su excitación. Era una especie de terror sacro. Similar al que puede producir la irrupción de lo numinoso. [...]

La bailarina dio vueltas en torno al yacente y por último se detuvo a su lado. El sintió la planta con frescura de mosaico que se apoyaba en su pecho caliente y palpitante de compungido plebeyo. (1 118$)$

Colón sintió que sus venas y arterias se llenaban de burbujeante vino de Champagne (o sidra, tal vez mejor, para 
describir el caso). [...] Sentía como los luchadores geniecillos de la sexualidad y la fecundación buscaban la periferia de toda su piel, desde el dedo gordo hasta la punta de la nariz. $[\ldots]$

Fue entonces cuando ingresó en el segundo panorgasmo. Sintió que toda su piel temblaba como el tapiz polvoriento que aporrea en la ventana la sólida criada portuguesa. [...]

No sería difícil hoy, a la luz de la ciencia psicoanalítica, explicarse el incidente: la genitalidad del plebeyo Colón había quedado bloqueada ante la presencia de la realeza. Era una inhibición surgida del sometimiento de clase. (119) Colón fue ungido como Almirante de la Mar Oceanía y se le permitiría el título de "Don". Aquel rito sellaba, según el texto de Posse, un gran acuerdo entre la reina Isabel y Colón: el establecimiento de una alianza para encontrar el "Paraíso Terrenal". ${ }^{13}$ Ambos se sienten llamados a cumplir una misión que transformará el destino de sus contemporáneos.

Tanto el Almirante, como los Reyes Católicos, surgen en el escenario internacional cuando el Medioevo, asediado por las fuerzas renacentistas, comenzaba a expirar en España. En referencia al matrimonio de Fernado e Isabel y el fin del Medioevo, dice la novela de 
Posse: "En el atormentado fornicio de aquellos adolescentes sublimes, fenece definitivamente la Edad Media" (70). Las metas de Colón, los Reyes Católicos y, aún el Papa Alejandro VI, involucraban, de acuerdo a esta novela, el rechazo de la ideología medieval que coartaba la libertad de acción individual e imponía trabas a la imaginación humana, generadoras de grandes obras.

Desde una perspectiva contemporánea, el razonamiento por el cual Rodrigo Borja surge como candidato ideal para el Papado, es buen ejemplo de ingeniosa racionalización: "Con visión de políticos geniales, Fernando e Isabel comprendieron que necesitaban un Papado a medida de su Imperio. Un vaticano rescatado del atroz letargo pietista" (Los perros 87). El Renacimiento y España necesitaban un papa mundano, de hombría indiscutible. Según la novela de Posse: "La misión del Cardenal valenciano Rodrigo Borja, justamente destacada por los historiadores, fue la oportunidad de definir un catolicismo imperial, cruel y renacentista" (87). Rodrigo Borja sería el Papa adecuado para los propósitos imperiales. A la edad de 42 años llegó a España desde Roma: la comunión históricamente decisiva entre Borja (el futuro Alejandro VI) y Fernando e Isabel requería una consagración. Esto ocurrió cerca de Alcalá el 27 de febrero de 1473. 
Era un amanecer no muy frío. Los jóvenes estaban en lo alto de una colina. Fernando movía su cuerpo y el de ella con una gran capa de fieltro que llegaba hasta el suelo. [...]

El cardenal, sin acompañamiento (había viajado en el mayor secreto), subió a pie hacia la cima. Ya más cerca pudo ver que en lo alto del cono del fieltro surgían las cabezas de Fernando e Isabel. [...] Fernando detrás de ella, contra ella y la poseía con serena continuidad. La capa se transformaba en morada, en apartamento de los tensos cuerpos enlazados. Las piernas entreabiertas de ella compensaba la menor altura del monarca - íncubo.

La escena tenía una inefable potencia ritual.

Alcanzaron el orgasmo - apenas un temblor de delicia cuando el prelado estaba a pocos pasos del mandala erótico. Era la suprema consagración, la santa nupcia, el engendramiento de la nueva Sinarquía.

Nacía el Imperio y una Iglesia Católica -imperial que arrojaba el lastre del torvo y beato cristianismo. (87-8)

La consagración de los móviles de pareja real y del cardenal valenciano tiene lugar en una escena en la cual el erotismo, es concebido como experiencia culminante, donde el individuo sale de los marcos espaciotemporales. 
Los personajes históricos, en Los perros del paraíso, y en general en las novelas de Posse, reciben un tratamiento diferente al que se les daba en las novelas históricas tradicionales, fundamentalmente las del siglo XIX y principio del XX. En aquellas novelas los personajes eran situados en un segundo plano, los personajes protagónicos eran inventados por el autor. Posse, sin embargo recrea figuras históricas y las hace protagonistas de sus novelas, haciendo una lectura de estos personajes desde el presente, no importa cual lejano sea su pasado. Posse recrea sus héroes de la misma manera en que estos vivieron: desafiando el orden establecido. Como bien plantea Fernando Aínsa: A estos héroes, a estos superhombres, Abel Posse los extrae de su contexto histórico para introducirlos en un espacio temporal en el que esa constante del héroe se repite y se reencarna continuamente con distintas formas. [...] Es decir, que hay toda una rencarnación, una reescritura constante del héroe mítico, y es en esa reescritura de los héroes míticos donde se inscribe la narrativa de Posse: los héroes son siempre los mismos, y son diferentes; los héroes son de ayer, de hoy y para siempre. Pero Posse no se limita a recuperar a los personajes para reescribir una historia ya sabida; él, si recoge los mitos, lo hace para desmitificarlos. (Abel Posse 70-1) 
El caso de Colón en Los perros del paraíso evidencia lo planteado, en esta novela de Posse hay una desacralización del personaje y un alejamiento del discurso mitificador.

En las novelas de Posse, al existir un distanciamiento en el tiempo, hay un enfriamiento de las pasiones heroicas de los personajes, los cuales en el presente de las obras de Posse ya no manifiestan el espíritu heroico del pasado. Son personajes que han sido derrotados por la historia y que fracasaron ante sí mismos. En los "héroes" de las novelas de Posse hay una intención de que éstos recuperen su condición humana. Al respecto Posse señala:

Yo creo que existe hoy en día una especie de nostalgia hacia la condición humana: Durante mucho tiempo, a través de la filosofía judeo - cristiana, se nos ha imbuido la creencia de que el ser humano es algo divino, algo hecho a imagen y semejanza de Dios; ahora, a finales del siglo XX, creemos que la condición humana es algo casi perverso. Estamos ante el fin del humanismo, y lo que yo planteo en algunas de mis obras es la necesidad de respetar o salvar esa condición humana, precisamente desde el punto de vista de aquéllos que menos humanos pueden parecer, como son los héroes. (Abel Posse 72) 
En los personajes históricos de las novelas de Posse, casi siempre, hay una especie de metáfora del fracaso en la historia de estos personajes. La mayoría de sus personajes, son hombres que han tratado de realizar unos sueños que nunca llegaron a cumplirse.

En conclusión, diremos que Los perros del paraíso es una novela que desmitifica al personaje histórico de Cristóbal Colón; a su vez, desacraliza a otros personajes protagonistas de la conquista de América. Usando la técnica narrativa de la aceleración del tiempo, la novela de Posse sintetiza sucesos históricos y como consecuencia recurre al anacronismo, distorsionando el discurso historiográfico tradicional como es característico en la nueva novela histórica hispanoamericana. Los perros del paraíso es una novela de pronunciada intertextualidad que se presenta tanto como visionaria anticipación de textos por venir como en transfiguración poética de viejos textos y antiguas tradiciones. La novela de Posse tiene una actitud revisionista de la historia que está en concordancia con su carácter irónico, dialógico, polífónico y carnavalesco. Esta novela introduce elementos nuevos en la reescritura de la historia, como la sexualidad dentro del discurso historiográfico; sus procedimientos de reescritura contribuyen a la reacomodación del discurso historiográfico tradicional.

La novela de Posse, con un discurso novomundista, reconstruye la historia desde una perspectiva contemporánea, ofreciendo una nueva 
aproximación a la historia del descubrimiento del llamado Nuevo Mundo. La novela denuncia los "vacíos" del discurso historiográfico y las supuestas falsedades de la historiografía oficial. El autor, a través de la integración de información proveniente de textos tradicionales y datos productos de su imaginación, crea un texto subversivo, de transgresión del discurso hegemónico. Los perros del paraíso ejemplifica a la nueva novela histórica en su corriente más actual. 


\section{NOTAS}

' En Los perros del paraíso, Posse narra desde una perspectiva externa y actual. El autor se entromete en la narración comentando los sucesos y haciendo referencia a hechos posteriores o que sólo se conocieron muchos años después.

${ }^{2}$ En una nota al pie de página (70) el autor textualmente dice:

En la angeología musulmana hay una clara referencia a esta categoría de ángeles que invaden la tierra, en retorno germinativo, devueltos por la ira de un dios acosado por la indiscreta pasión cognoscitiva del humano. EL angelos es sustancialmente el mensajero (léase a Henri Corbin). También Proclo los consideró (Teología Platonica, libro I): en su forma menos sofisticada y más "humana", asumen el carácter de daimones y de héroes. Para Santo Tomás y los escolásticos, Fernando e Isabel ingresarían en la tercera jerarquía (la más inmediata a la naturaleza humana). Casi unánimemente los angeologistas convienen en la terribilidad e insolencia de estos seres que moran al margen del código cristiano: no necesitan salvarse. No necesitan ni fe, ni esperanza, desconocen la caridad. Probablemente les repugne la piedad. Sólo se atienden a las leyes de su misión.

${ }^{3}$ Juan José Barrientos en Historia-Ficción lo plantea en términos distintos cuando dice que: "Alejo Carpentier quiso desmitificar a Colón y en cambio Abel Posse se propone remitificarlo" (56).

${ }^{4}$ Ambas novelas concuerdan en algunos aspectos pero se oponen en otros. El Colón de la novela de Carpentier no se proponía viajar al Oriente por el Poniente sino apoderarse de las tierras situadas al sur de las que habían hallado los vikingos. En la novela de Posse el objetivo del Almirante era encontrar el paraíso terrenal.

${ }^{5}$ El estilo de Posse en Los perros del paraíso contrasta con el estilo arcaizante de Carpentier en El arpa y la sombra. Ambas novelas tienen a Colón como protagonista, pero se contraponen en varios aspectos como hemos señalado.

${ }^{6}$ De cierta manera el texto de Posse es una reescritura postmoderna de la Breve relación de la destrucción de las indias de Bartolomé de las Casas, en la que los europeos y el capitalismo son acusados de los daños ocasionados al "Nuevo Mundo". La novela incluye acusaciones de tipo ecologistas por los estragos que sufrieron la vegetación y los animales en las tierras conquistadas.

${ }^{7}$ Esta novela de Posse se fundamenta en la idea de Colón, expresada al regreso de su tercer viaje, sobre el descubrimiento que el Almirante cree haber hecho del Paraíso Terrenal. Al parecer, los diarios del primer y tercer viaje son los documentos históricos más utilizados y "manipulados" por el autor de la novela.

8 Los pasos perdidos es una metáfora de un viaje de conquista de un espacio mítico, un viaje al origen perdido por el hombre que vive en el mundo apocalíptico de la modernidad.

${ }^{9}$ Posse niega que Colón fuera judío. Carpentier, por el contrario, lo afirma en El arpa y la sombra. Posse, en su reescritura, cuenta como Colón de niño fue llevado por el padre 
a un judío no muy ortodoxo para que le realizara la circuncisión con un corte "ambiguo" con la intención de satisfacer a los banqueros judíos sin exponer al joven al rencor antisemita.

${ }^{10}$ La relación de Colón con Beatriz de Bobadilla ha sido tema de interés de los historiadores. Samuel Eliot Morison es uno de los historiadores que escribió sobre el tema, en su obra Admiral of the Ocean Sea dice que "En la época de la visita de Colón, la enérgica viuda todavía no tenía treinta años y se sabe de buena fuente que se enamoró de ella" (162). Sin embargo, el historiador Jacques Heers niega esta posibilidad cuando en su obra Christophe Colomb plantea que: "Varios autores [...] interpretaron un comentario bastante anodino de Michel de Cuneo, compañero de Colón durante el segundo viaje, acerca de la belleza y la admiración que inspiraba a todos, para construir sobre este encuentro toda una historia de amor entre Colón y Beatriz" (230). Posse toma partido por la tesis de Samuel Eliot Morison.

"Posse le concede bastante atención a los personajes de Fernando e Isabel, especialmente al de Isabel. Los capítulos relacionados con la reina se alternan con los que se refieren a Colón.

${ }^{12}$ Posse prefiere presentar a Colón como amante de Beatriz de Bobadilla, viuda de Hernán Peraza, que gobernaba la Gomera cuando Colón se detuvo en esa isla durante su primer viaje.

${ }^{13}$ En la reelaboración que Posse hace de los hechos, la noticia de que Colón había descubierto el paraíso terrenal hizo desconfiar al clero, a las comunidades hebreas, y a los españoles que querían establecerse en las tierras descubiertas. Para el clero era peligrosa la explicación que se le daba al descubrimiento, la cual ponía a Colón y a la reina más cerca de Dios que a ellos. Los hebreos buscaban tierras para terminar la diáspora, no el "Paraíso Terrenal". Y la gente del pueblo quería tierras donde enriquecerse por lo que les disgustaba el hecho de ir en unas tierras donde sus nativos, según el Almirante sugería, eran ángeles. 


\section{Conclusiones}

Las primeras manifestaciones de lo que pudiéramos llamar novelas históricas hispanoamericanas surgen en el siglo XIX dentro del marco estético del Romanticismo y el Realismo. Estas primeras novelas históricas buscaban en el pasado las raíces que ayudaran a definir la identidad nacional, se atenían a lo relatado por la historia oficial y se proponían una recreación fiel del marco histórico local o nacional. Los autores de estas novelas intentaban lograr una reproducción de la realidad sociohistórica sin cuestionar las "verdades" del discurso historiográfico tradicional.

La novela histórica hispanoamericana inicia su transformación en la segunda mitad del siglo XX con la publicación de El Reino de este mundo (1949). En esta novela se rescribe el pasado a partir de un minucioso estudio de los textos históricos tradicionales, a los que se unen otros de tipo mitológico y religioso. De esta manera, Carpentier abre las puertas a una de las técnicas con que se caracterizará a partir de entonces la nueva novela histórica hispanoamericana: el pastiche intertextual. El reino de este mundo ejemplifica el rigor documental e informativo característico de las novelas de Carpentier, pero también su capacidad para integrarse dentro de un discurso híbrido y amargo. 
El siglo de las luces es otra de las novelas de Carpentier cuya narración está apoyada por un intenso trabajo de archivo. La fidelidad a las fuentes tradicionales ha sido reconocida por el propio autor al ofrecer antecedentes sobre cómo concibió esta novela y las fuentes en las que se apoyó para su redacción. La novela también muestra la tarea de indagación por parte del autor de la filosofía, la música, las artes plásticas, la literatura y el lenguaje de los períodos históricos que se recrean en la obra: los siglos XVIII y XIX.

El siglo de las luces es un texto que permite múltiples lecturas. La multiplicidad de perspectivas es, de hecho, uno de los rasgos distintivos de la nueva novela histórica hispanoamericana. Esta novela de Carpentier, se destaca también por su carácter filosófico y autoconsciente, lo que permite considerar este texto no sólo como una reflexión novelística sobre un período histórico sino también como una metahistoria. Esta condición mencionada está en concordancia con el planteamiento de Hayden White, estudiado en el primer capítulo, de que no puede haber una historia propiamente dicha que no sea a la vez una filosofía de la historia. Este carácter auto-reflexivo de El Siglo de las luces, es una de las características del nuevo historicismo, al cual se adscribe la nueva novela histórica hispanoamericana.

Si bien es cierto que Carpertier hizo su aporte a la trasformación de la novela histórica en Hispanoamérica, no es menos cierto que la 
trasformación radical de la novela histórica hispanoamericana comienza con la publicación de la novela El mundo alucinante (1969) de Reinaldo Arenas. A partir de entonces, las novelas históricas hispanoamericanas se alejan de la rigurosa documentación y recreación de la Historia basada en los textos canónicos y se inicia la actual tendencia de la nueva novela histórica, que tiene muchos puntos de contacto con el modo narrativo que Linda Hutcheon Ilama "metaficción historiográfica".

Existe una relación entre la actual tendencia de la nueva novela histórica en Hispanoamérica y el postmodernismo en general. Esta tendencia puede ser considerada como una variedad particular dentro de la metaficción postmodernista. La ficción postmodernista permite la participación activa del lector, que adquiere una identidad compuesta con el escritor y el crítico. En contraposición con el historicismo empírico y objetivista de la historiografía tradicional, el postmodernismo desconfía de las estructuras fijas y las verdades fundamentales. La nueva novela histórica, en su corriente más actual, cuestiona las verdades del discurso oficial porque éstas son vistas como construcciones sociales determinadas por la ideología dominante y el discurso del poder.

El discurso ficcional hispanoamericano se ha caracterizado en los últimos años por un marcado interés por los temas históricos. Los escritores hispanoamericanos parecen responder a una necesidad de profundizar en la historia para incorporar el imaginario social e individual 
de acontecimientos pasados a la ficción. La nueva novela histórica hispanoamericana, como acertadamente plantea Fernando Aínsa: se ha embarcado, así, en la aventura de releer la historia, especialmente crónicas y relaciones, ejercitándose en modalidades acrónicas de la escritura, en el pastiche, la parodia y el grotesco, con la finalidad de deconstruir la historia oficial” (“La nueva novela histórica latinoamericana."

La nueva novela histórica hispanoamericana, a través de formulaciones estéticas nuevas, rescata la oralidad, el imaginario popular y colectivo presente en nuestros mitos y tradiciones; a la vez que también incorpora formas arcaicas como las parábolas y las leyendas. Las novelas históricas escritas en los últimos años en Hispanoamérica se caracterizan, en general, por cuestionar y desmontar las "verdades" de la historiografía tradicional con un discurso carnavalesco, grotesco e irreverente. Estas novelas usan la intertextualidad, el anacronismo, la sátira, el humor como instrumento para deconstruir la historia oficial y el discurso del poder.

El tema del "descubrimiento" de América y la conquista ha estado presente en la narrativa hispanoamericana desde sus orígenes; pero no es menos cierto, que dentro del marco de la actual corriente de la nueva novela histórica hispanoamericana, se ha incrementado el interés de los novelistas por el tema. Este interés y las aproximaciones postmodernas a 
la historia han producido una serie de novelas que podríamos llamar del "redescubrimiento", las cuales tienen un discurso novomundista que se aleja de la concepción eurocéntrica de la historia del discurso historiográfico oficial.

Los personajes históricos que más han sido recreados en estas novelas centradas en torno al tema del "descubrimiento" y la conquista son Cristóbal Colón y Lope de Aguirre. El estudio de estos personajes revela la existencia de vacíos en el archivo histórico. La nueva novela histórica hispanoamericana, en su actual aproximación a la historia intenta llenar estos vacíos, reconstruyendo la existencia de esos personajes a la vez que reflexiona y cuestiona las "verdades" aceptadas por el discurso historiográfico.

La primera novela, dentro de la actual corriente de la nueva novela histórica centrada en el tema del descubrimiento y la conquista y el personaje de Colón, es El arpa y la sombra (1979). Otras reconstrucciones más recientes de este personaje dentro del marco de la nueva novela son Los perros del paraíso (1987), de Abel Posse, y Vigilia del Almirante (1992), de Augusto Roa Bastos. Las tres novelas han sido analizadas en este trabajo.

Dentro de la novelística hispanoamericana el primer novelista que recrea al personaje de Lope de Aguirre es Arturo Uslar Pietro, en su novela El camino de El Dorado (1947). Dentro del marco de la nueva 
novela histórica, en su corriente más actual, la novela de Otero Silva Lope de Aguirre, príncipe de libertad (1979) es la primera que reescribe la vida de Lope. Esta novela inserta un nuevo modo de visualizar al personaje histórico, tratando de develar nuevas intenciones y propósitos que la nueva novela histórica tradicional no desarrolló. El autor rescata la figura del conquistador a favor de una actitud libertaria.

Abel Posse, uno de los autores más destacados de la nueva novela histórica hispanoamericana, también recrea la controvertida figura de Lope de Aguirre, al cual convierte en protagonista de Daimón. Esta novela, planificada como un gran collage de variados registros temáticos, es una peculiar diacronía que asume al menos quinientos años del pasado americano. El autor, utilizando el lenguaje irreverente, contestatario y desmitificador de la novela hispanoamericana en su tendencia más actual, transforma a Lope de Aguirre de protagonista a testigo invisible de la historia. A través de la parodia, el humor y el anacronismo, Posse nos entrega un texto indagador y crítico de la historia hispanoamericana.

Otra novela del mismo autor que ejemplifica la actual novela histórica hispanoamericana y su discurso novomundista es El largo atardecer del caminante (1992), novela centrada en el fascinante personaje histórico Álvar Nuñez Cabeza de Vaca. El largo atardecer del caminante sigue los postulados de la nueva filosofía de la historia de 
Hayden White. Al igual que White, Posse cuestiona la distinción entre "el discurso histórico" y "discurso ficticio", afirmando la función legítima de la imaginación en la representación de la realidad.

Esta novela de Posse se enmarca dentro de la más actual tendencia de la nueva novela histórica hispanoamericana. El largo atardecer del caminante desmiente la historia oficial y la obra que parodia. El protagonista crea un discurso alternativo, mediante el cual intenta entender y redimir sus errores pasados. La idea de Borges de que toda literatura es, en última instancia, el arte del palimpsesto, se ejemplifica así en la novela de Posse.

El largo atardecer del caminante, como toda la novelística de Posse resulta una crítica abierta a la visión eurocéntrica que ha tenido el discurso histórico tradicionalmente e intenta llenar ciertos vacíos existentes de la historiografía oficial. La veracidad de todo discurso histórico, cuestión muy debatida hoy por la crítica postmoderna, es uno de los temas fundamentales de la obra de Posse. La novela de Posse puede ser considerada una novela postmoderna al proponer que el pasado histórico sólo se puede conocer con limitaciones. Esta novela confirma el carácter mediatizado de todo discurso histórico y la imposibilidad de la representación mimética de la realidad.

Una de las novelas de Posse que más se aproxima a la historia con una perspectiva contemporánea y un discurso novomundista es LoS 
perros del paraíso (1987). Posse recrea, como ya lo había hecho Carpentier en El arpa y la sombra (1979), a Cristóbal Colón desde una óptica que se aleja del discurso tradicional, invirtiendo las categorías y los estereotipos de la historia oficial. Posse también aleja al personaje histórico de Isabel de Castilla del discurso devoto y canonizador de determinados historiadores. A su vez Colón es visto desde una perspectiva poco explorada por la historiografía oficial: como buscador del Paraíso Terrenal.

Los perros del paraíso es un buen ejemplo de cómo la nueva novela histórica hispanoamericana, en su tendencia más actual, promueve la inversión de la historia oficial utilizando recursos paródicos para darnos una nueva visión de personajes históricos. La representación de personajes y sucesos narrados desde la óptica irreverente, desacralizadora y contestataria del autor, le otorgan al subtexto histórico de esta novela un carácter subversivo que cuestiona el discurso histórico oficial. Posse, en esta novela, reitera sus rasgos estilísticos, desmontando el tiempo y rearmando la historia con formas nuevas. El autor, con una intención lúdica, asocia libremente elementos del pasado con los del presente; transforma la historia, la hiperboliza y la convierte en una realidad a veces alucinante.

Las novelas de Alejo Carpentier El reino de este mundo (1949) y EI siglo de las luces (1962), caracterizadas por su didactismo y una 
aproximación a la historia fundada en el historicismo, se enmarcan en la primera tendencia de la nueva novela histórica. Al final de su vida, el autor se aproxima con la novela El arpa y la sombra (1979, a la actual tendencia de la nueva histórica hispanoamericana, que inició Reinaldo Arenas, con El mundo alucinante (1969). La segunda y actual corriente de la nueva histórica, como hemos planteado, se caracteriza por un discurso ficcional irreverente, paródico, irónico y carnavalizado.

Aunque en El arpa y la sombra hay un cuestionamiento de algunas "verdades" históricas, el texto evita establecer una nueva verdad definitiva. Este relativismo epistemológico está en concordancia con los postulados deconstruccionistas, que establecen que no existe un significado definitivo o verdadero sino intentos de aproximación, de lecturas, que corrigen otras lecturas. El arpa y la sombra se adscribe a la actual tendencia de la nueva novela histórica hispanoamericana mediante el uso de la autociencia literaria, la parodia, y el revisionismo historiográfico, además de reunir muchos de los rasgos paradigmáticos que Seymour Menton y Fernando Aínsa otorgan a la actual novela histórica escrita en Hispanoamérica.

Las novelas que se adscriben a la tendencia actual de la nueva novela histórica ejemplifican lo que teóricos como Linda Hutcheon y Brian MacHale han denominado metaficción historiográfica y ficción postmodernista, respectivamente; se caracterizan por tener un discurso 
hiperbólico y grotesco. Son textos donde abunda la intertextualidad, el dialogismo y el anacronismo. Estas novelas intentan reconstruir creencias y valores establecidos por la historia oficial y el discurso del poder, desmontando las posibilidades de conocer las "verdades" de la historia. 


\section{Bibliografía}

\section{FUENTES PRIMARIAS}

Carpentier, Alejo. El siglo de las luces. Segunda Edición. México:

Compañía General de Ediciones, 1965.

- - - La música en Cuba. México: Fondo de Cultura Económica, 1972.

- -. El siglo de las luces. Argentina: Editorial Quetzal, 1978.

- -. "Sobre El arpa y la sombra". Conferencias. La Habana: Letras Cubanas, 1987.

- -. El arpa y la sombra. México: Siglo XXI, 1990.

- -. El reino de este mundo. Barcelona: Seix Barral, 1994.

- - Prólogo. El reino de este mundo. Río Piedras, Puerto Rico: EDUPUR, 1994.

Posse, Abel. El largo atardercer del caminante. Buenos Aires, Argentina: Emecé editores, 1998.

- - . Los perros del paraíso. Buenos Aires, Argentina: Emecé editores, 1995.

- - Daimón. Buenos Aires, Argentina: Emecé editores, 1991.

- - -. "El alucinante viaje del doble descubrimiento". 1492-1992. A los 500 años del choque de dos mundos". Balance y prospectiva. Buenos Aires: Argentina, Ediciones del Sol, 1989. 197-208.

\section{FUENTES SECUNDARIAS}

Acevedo, Federico. "Introducción". El reino de este mundo. Río Piedras, Puerto Rico: EDUPUR, 1994. ix-xlviii.

Acosta, Leonardo. "El almirante según don Alejo". Casa de las américas. 121 (1980): 26-40. 
Aínsa, Fernando. Identidad cultural de Iberoamérica en su narrativa. Madrid: Gredos, 1986.

- - -. "La reescritura de la historia". Cuadernos Americanos 28. (1991): 9-31.

- -. "La nueva novela histórica". Plural 240 (septiembre, 1991): 82-85. Anzoátegui, Ignacio B. (ed.) Los cuatro viajes del Almirante y su testamento. Madrid: Espasa - Calpe, 1977.

Álvar, Núñez Cabeza de Vaca. Naufragios y Comentarios. México: Editorial Porrúa, 1997.

Amorós, Andrés. Introducción a la novela hispanoamericana actual. Salamanca: Anaya, 1971.

Arias, Salvador. "Habla Alejo Carpetier". Recopilación de textos sobre Alejo Carpentier. Compilación y prólogo de Salvador Arias. La Habana: Casa de Las Américas, 1977.

Arenas, Reinaldo. El mundo alucinante. Barcelona: Montesinos, 1981.

Baccino Ponce de León, Napoleón. Maluco. La novela de los descubridores. Barcelona: Seix Barral, 1990.

Bajtin, Mijail. Teoría y estética de la novela (Trabajos de investigación) Madrid: Taurus, 1989.

Barrientos, Juan José. Ficción - historia. La nueva novela histórica hispanoamericana. México: Universidad Nacional Autónoma de México, 2001.

Baroja, Pío. Las inquietudes de Shanti Andía. Madrid: Cátedra, 1981.

Batllori, Miguel y Pedro Leturia. La primera misión pontificia a Hispanoamérica, 1823-1825; relación oficial de Giovanni Muzi. Città del Vaticano: Biblioteca apostólica Vaticana, 1963.

Bellegarde, Dantés. La Nation Haïtienne. París: J. de Gigord Éditeur, 1936.

Binns, Nialls. "La novela histórica hispanoamericana en el debate postmoderno". La novela histórica a finales del siglo XX. José Romera Castillo, Francisco Gutiérrez Carbajo y Mario García-Page. (Eds.) Madrid: Visor, 1996. 159-166. 
Blasco Ibáñez,Vicente. En busca del gran Kan.Obras Completas. Vol. III. Madrid: Aguilar, 1997.1181-1472.

Bost, David y Julia Cuervo Hewitt. Entrevista de David Bost y Julia Cuervo Hewitt con Antonio Benítez Rojo. N.p:,Vanderbilt University, 1978.

Calvino, Italo. The Castle of Crossed Destinies. New York: Harcourt Bruce, 1977.

Chao, Ramón. Palabras en el tiempo de Alejo Carpentier. Barcelona: Arcos Vergara, 1984.

Claudel, Paul. Le livre de Cristophe Colomb. París: n.p., 1930.

Cortázar, Julio. Obra critica II. Madrid: Alfaguarra, 1994.

Cole, Hubert. Christophe, King of Haití. New York: The Viking Press, 1967.

Colón, Cristobal. Libro de Profecías. ed. de Juan Fernández Valverde. Madrid: Alianza, 1992.

Colón, Hernando. Historia del Almirante. Ed. Luis Arranz. Madrid: Historia 16, 1985.

Cuervo Hewitt, Julia. "Crónica de un deseo: re(in)sistencia, sub-versión y re-escritura en El mar de las lentejas de Antonio Benítez Rojo". Revista Iberoamericana. 62-175. (1996): 461-76.

de Saint-Méry, Moreau. Description topographique,physique,civile, politique et historique de la partie francaise de l'lle de SaintDomingue. Paris: L.Guérin et Cie, 1875.

de Vaissiere, Pierre. Saint-Domingue, la société et la vie créole sous l'Ancient Régime (1629-1 789).París: Librairie Académique, 1909.

Dill, Hans-Otto. "El siglo de las luces, de Alejo Carpentier: primerísima auténtica novela histórica latinoamericana". La invención del pasado: la novela histórica en le marco de la posmodernidad. Ed. Karl Kohur. Madrid: Iberoamericana, 1997. 205-215. 
Domínguez, Mignon, proyecto y coordinación. Historia, ficción y metaficción en la novela latinoamericana. Aregentina: Corregidor, 1996.

Dumas, Claude. "El siglo de las luces, de Alejo Carpentier; Novela Filosófica". Homenaje a Alejo Carpentier: Variaciones interpretativas en torno a su obra. New York: Las Américas Publishing Co., 1970. 325-363.

Eliade, Mircea. El mito del eterno retorno. Barcelona: Alianza/Emecé, 1985.

Fama, Antonio. "Historia y naración en El arpa y la sombra, de Alejo de Alejo Carpentier". Revista Iberoamericana 52.135-136 (1986): 54757.

Fernández, Sinesio. "El mito de de Sísifo" en El siglo de las luces". Festschrift (1981): 243-246.

Fèvre, Fermín. Modernidad y postmodernidad en el arte. Argentina: Fundación de Arte de Ana Torre, 1994.

Feyerabend, Paul. Tratado contra el método. Madrid: Tecnos, 1981.

Foucault, Michel. Power/Knowledge. New York: Pantheon, 1980.

- - . El orden del discurso. Barcelona: Tusquet editores, 1980.

- - Language Counter-Memory, Practice. Selected Essays and Interviews. Ithaca, New York: Cornell University Press, 1977.

Frye, Northrop. Anatomy of Criticism. Londres: Penguin Books, 1990.

Fuentes, Carlos. Valiente mundo nuevo: épica, utopía y mito en la novela hispanoamericana. Madrid: Mondadori, 1990.

Galster. Ingrid "El conquistador Lope de Aguirre en la Nueva Novela Histórica". La invención del pasado; la novela histórica en el marco de la postmodernidad. Madrid: Iberoamericana, 1997. 196-204.

Gandía, Enrique de. Historia de Cristóbal Colón: Análisis crítico de las fuentes documentales y los problemas colombinos. México: Ediciones Latinoamericanas, 1953. 
García Pinto, Magdalena. "Entrevista con Abel Posse". Revista Iberoamericana 55.146-7. (1989): 493-506.

Gómez Ferreyra, Avelino Ignacio. Viajeros pontificios al Río de la Plata y Chile: la primera misión pontificia a Hispano-América relatada por sus protagonistas. Córdova, Argentina: Gobierno de la Provincia de Córdova, 1970.

González Echevarría, Roberto. Myth and archive. A theory of Latin American narrative. Durham: Duke University Press, 1998.

- -. "Historia y alegoría en la narrativa de Alejo Carpentier". Cuadernos Americanos 228. (1980): 200-20.

- - . "Alejo Carpentier". Narrativa y crítica de nuestra América. Madrid: Castalia, 1978. 127-60.

- -. Alejo Carpentier: The pilgrim at Home. Ithaca: Cornell University Press, 1977.

- - - "Isla a su Vuelo Fugitiva: Carpentier y el Realismo Mágico". Revista Iberoamericana 40 (1979): 9-63.

Graves, Robert. Yo, Claudio. Traducción de Floreal Mazía. Barcelona, Edhasa, 1983.

Hales, Edward Elton. Pio Nono: a study in European politics and religion in the nineteenth century. Garden City: Doubley, 1962.

Harss, Luis. Los nuestros. México: Editorial Hermes, 1984.

Heers, Jacques. Christopher Colomb. París: Hachette, 1981.

Henríquez Ureña, Pedro. La utopía de América. Ed. Ángel Rama y Rafael Gutiérrez Girardot. Barcelona: Ayacucho, 1989.

Heydenreich, Titus. "Il viaggio in cile (1823- 25) di Giovanni Maria Mastai (1846 - 78, Papa Pío IX): Conseguenze politiche e letterarie" $L a$ letteratura di viaggio: Storia e prospective di un genere letterario. Ed. Maria Enrica D’Agostini. Milano: Guerini, 1987. 161-169. 
Hughes, Psiche. "The Visual And Performing Arts In The Work Of Alejo Carpentier: El siglo de las luces. Revista Interamericana.13.1-4 (1983): 126-137.

Humbold, Alejandro de. Cristóbal Colón y el descubrimiento de América. Caracas: Monte Ávila, 1992.

Hutcheon, Linda. Narcissistic Narrative. The metaficcional paradox. Waterloo, Ontario, Canada: Wilfred Laurier Univeristy Press, 1980.

Hutcheon, Linda. "Theorizing the Postmodern". Twentieth-Century Literary Theory: A Reader. New York: New York Pagination, 1997. 275- 82 .

- -. "The Pastime of Past Time": Fiction, History, Historiographical Metafiction. Essential of the Theory of fiction. Durham: Duke University Press, 1996. 472-95.

- - . A poetics of postmoderism. London and New York: Routledge, 1988.

lacoviello, Beatriz. "Entrevistas: Abel Posse". Espéculo 10 (1998-1999). 17 January1 999. <http://www.ucm.es/info/espéculo/numero10/ a_posse.html>

Imbert, Enrique Anderson. Historia de la literatura hispanoamericana. México: Fondo de Cultura Económica, 1974.

Irving, Washington. Vida del almirante Don Cristóbal Colón. Madrid: Istmo, 1990.

Jenkins, Keith. Re - thinking History. London and New York: Routledge, 1991.

- - . On 'What is History?’. London and New York: Routledge, 1995.

-.. Why history ? Ethics and postmodernity. London and New York: Routledge, 1999.

Jos Emiliano. La expedición de Ursúa al Dorado, la rebelión de Lope de Aguirre y el itinerario de los "marañones" según los documentos del Archivo de Indias y varios manuscritos inéditos. Huesca: Imprenta V. Campo, 1927. 
Juan-Navarro, Santiago. "El arpa y la sombra: o la Lipsonoteca postmodernista de Alejo Carpentier". First International Conference on Caribbean Literature. Nassau, Bahamas. November 5-6. 1998.

- -. Archival Reflections: Postmodern Fiction of the Americas (SelfReflexivity, Historical Revisionism, Utopia) Lewisburg and London: Bucknell and Associated University Press, 1999.

- - . A Twice-Told Tale: Reinventing the Encounter in Iberian/Iberian American Literature and Film. Edited by Santiago Juan-Navarro and Theodore Robert Young. Newark: University of Delaware Press, 2001.

Kahler, Eric. The meaning of History. Cleveland and New York: TheWorld Publishing Company, 1968.

Kaplan, Marina E. "Daimón o la ausencia del padre". Utopías del Nuevo Mundo. Prague: Charles University, 272-86.

Kristeva, Julia. "Post modernism?" Garvin (1980): 136 - 41.

LaCapra, Dominick. History \& Criticism. London and Ithaca: Cornell University Press, 1985.

Leante, Cesar. "Confesiones sencillas de un escritor barroco". Recopilación de textos sobre Carpentier. La Habana: Casa de las Américas, 1977. 15- 56.

Leconte, Vergniaud. Henri Christophe dans l'Histoire d'Haïti. París: Ediciones Berger-Levrault, 1931.

Lefebre, Robin. "Sentidos y alcance de Vigilia del Almirante de A.Roa Bastos". Bulletin of Hispanic Studies 76. 4. (1999): 535-55.

- - -."Historia y ficción: la figura de Lope de Aguirre". 1898 - 1998: fines de siglos: historia y literatura hispanoamericanas. Genéve: Droz, 2000.

Lozano, Jorge. El discurso histórico. Madrid: Alianza, 1987.

Lukács, Georg. La novela histórica. Trad. Manuel Sacristán. Barcelona: Grijalbo, 1976. 
Lyotard, Jean François. La condición postmoderna. Trad. Antolín Rato. Informe del saber. Madrid: Cátedra, 1994.

MacHale, Brian. "Some Postmodernist Stories". Postmodern Fiction in Europe and the Americas. Ed. Theo D'haen and Hans Berten. Amsterdam: Rodopi, 1988. 13-26.

- - Postmodern Fiction. London y New York: Methuen, 1987.

Madariaga, Salvador de. Vida del muy Magnífico Señor Don Cristóbal Colón. México: Hermes, 1992.

Marbán, Jorge. "La visita en el tiempo de Arturo Uslar Pietri: Estructuras míticas en una novela histórica". Explicación de Textos Literarios 22 (1993-1994): 35- 41.

Martina, Giacomo. Pio IX. Roma: Università gregoriana, 1974-1990.

Márquez Rodríguez, Alexis. Acción y pasión en los personajes de Miguel Otero Silva y otros ensayos. Caracas: Academia Nacional de la Historia, 1985.

- -. Historia y ficción en la novela venezolana. Caracas: Monte Ávila, 1992.

- -. Abel Posse. Luis Saínz de Medrano, Editor. Madrid: Ediciones de Cultura Hispánica, 1997.

Méndez y Soto, E. "La trayectoria revolucionaria de El siglo de las luces. Explicación de Textos Literarios 5.2 (1976): 221-26.

Menton, Seymour. "La historia de Álvar Núñez Cabeza de Vaca en la última novela de Abel Posse, El largo atardecer del caminante" Revista Iberoamericana 62.175 (1996): 421-26.

- -. La nueva novela histórica de la América Latina

1979 - 1992. México: Fondo de Cultura Económica, 1993.

- -. La narrativa de la Revolución Cubana. Madrid: Playor, 1978.

Metraux, Alfred. Vodú. Versión castellana de Jorge Eneas Cromberg. Santo Domingo: Alfa y Omega, 1979. 
Meyer-Minnemann, Klaus. "La novela modernista hispanoamericana y la literatura europea de fin de siglo: Puntos de contacto y diferencias". Nuevos asedios al modernismo. Ed. Ivan A. Schulman. Madrid: Taurus, 1987. 246-261.

Morrison, Samuel Eliot. Admiral of the Ocean Sea. Boston: Little Brown and Company, 1942.

Nietzsche, Friedrich. A genealogy of Morals. Trad. Maudemarie Clark and Alan J. Swensen. Indianapolis and Cambridge: Hackett Publishing Company, 1998.

- - -. Obras Inmortales. Barcelona: Eicomunicación, 2000.

Nye, Rusel. "History and Literature: Branches of the same tree". Essays on History and Literature. Columbus: Ohio State University Press, 1966. 123-59.

O'Gorman, Edmundo. La invención de América: investigación acerca de la estructura histórica del nuevo mundo y del sentido del devenir. México: Fondo de Cultura Económica, 1984.

Otero Silva, Miguel. Lope de Aguirre, príncipe de libertad.Barcelona: Seix Barral, 1980.

Ortega, Julio. "Postmodernism in Latin America". Postmodern Fiction in Europe and the Americas. Edited by Theo D'haen and Hans Berten. Amsterdam: Rodopi. (1988): 193 - 208.

Pastor. Beatriz. Discursos narrativos de la conquista: Mitificación y emergencia. Segunda edición corregida. Hannover, $\mathrm{NH}$ : Ediciones del Norte, 1988.

Parkinson Zamora and Wendy B. Faris, editors. Magical realism. Theory, History, Community. Durham and London: Duke University Press, 1995.

Pattee, Ricardo. Haiti pueblo africano. Madrid: Ediciones Cultura Hispánica, 1956.

Puleo, Alicia. "El siglo de las luces: Dialéctica de la razón y la pasión". Castilla: Boletín del Departamento de Literatura Española 17 (1992): 103-13. 
Regazzoni, Linda. "La ironía de la historia en el Caribe de Alejo

Carpentier. Rassegna Iberistica. 56. (1996): 105-12.

Roa Bastos, Augusto. Vigilia del Almirante. Madrid: Alfaguarra, 1992.

Rodríguez Monegal, Emir. "Trayectoria de Alejo Carpentier". Narradores de esta América. Buenos Aires: Alfa, 1976.

Rozencvaig, Perla. Reinaldo Arenas: narrativa de transgresión. México: Oasis, 1986.

Sábada, Javier. "¿El fin de la historia? La crítica de la postmodernidad al concepto de historia como metarrelato". Filosofía de la historia. Edición de Reyes Mate. Madrid: Trotta, 1993. 193-205.

Saer, Juan José. El entenado. México: Folio ediciones, 1983.

Safranski, Rüdiger. Nietzsche. Biografía de su pensamiento. Barcelona: Tusquets, 2001.

Sáinz de Medrano, Luis. ed. Abel Posse. Madrid: Ediciones de Cultura Hispánica, 1997.

Sallusti, Giuseppe. Historia de las misiones apostólicas de Monseñor Juan Muzi en el estado de Chile. Santiago de Chile: Lourdes, 1906.

Sánchez, Reinaldo, editor. Reinaldo Arenas: Recuerdo y presencia. Miami: Universal, 1994.

Santander, Carlos. "Historicidad y alegoría en El siglo de las luces". XVII Congreso del Instituto Internacional de Literatura Iberoamericana. Madrid: Ediciones de Cultura Hispánica, 1975. 499-510.

Santi, Enrico Mario. "Entrevista con Reinaldo Arenas. Vuelta. 47. (octubre, 1980). 23-29.

Sender, Ramón J. La ventura equinoccial de Lope de Aguirre. Barcelona: Bruguera, 1981.

Serafini, Alberto. Pio Nono: Giovanni Maria Mastai Ferreti dalla giovinezza alla morte nei suoi scritti e discorsi editi e inetiti. Cittá del Vaticano: Poliglotta Vaticana, 1958. 
Serra, Ana. "La revolución como simulacro en El reino de este mundo y EI siglo de las luces de Alejo Carpentier. RLA: Romance Languages Annual 7 (1995): 621-25.

Sevilla, José. "El concepto de la filosofía de la historia". Filosofía de la historia. Edición de Reyes Mate. Madrid: Trotta, 1993. 65-84.

Shaw, Donald L. Nueva narrativa hispanoamericana. Madrid: Cátedra, 1988.

Smith, Esther. "La novela en la historia: un encuentro metaficcional". Historia, ficción y metaficción en la novela latinoamericana contemporánea. Argentina: Corregidor, 1996.

Speratti- Piñero, Emma Susana. Los pasos hallados en El reino de este mundo. México: Colegio de México, 1981.

Spiller, Roland. "Conversación con Abel Posse". Iberomericana 13. 2-3 (1989): 37-38.

Tatham, Campbell. "Tarot and Gravity's Rainbow”. Modern Fiction Studies. 32. 4 (1986): 581-590.

Todorov, Tzevan. La conquista de América. El problema del otro. México: Siglo Veintiuno Editores, 1997.

Usable González, Antonio. La novela histórica hispanoamericana: desde 1931 hasta nuestros días. Madrid: Ediciones de la Universidad Autónoma de Madrid, 2000.

Uslar Pietri, Arturo. Godos, insurgentes y visionarios. Barcelona: Seix Barral, 1990.

- -. La visita en el tiempo. Madrid: Mondadori, 1990.

- - El camino de El Dorado. Epílogo de Alexis Márque Rodríguez. Caracas: Monte Avila editores, 1992.

- - . Las lanzas coloradas. Ed. Domingo Miliani. Madrid: Cátedra, 1993.

Valero, Roberto. El desamparado humor de Reinaldo Arenas. Miami: North-South Center. University of Miami. 1991. 
Vargas Llosa, Mario. La verdad de las mentiras. Barcelona: Seix Barral, 1990.

- - . "Extemporáneos. ¿Lo real maravilloso o artimañas literarias?". Letras Libres. México: Editorial Vuelta. 2.13 (1999): 32-36.

Velayos Zurdo, Oscar L. Historia y Utopía en Alejo Carpentier. Ediciones Universidad de Salamanca, 1990.

Vich, Cynthia. "El dialogo intertextual en Maluco". Revista Iberoamericana. Vol. 63. 180. (1997): 405-418.

Waite, Arthur. The Pictorial Key to the Tarot. Secasus, New Jersey: Citadel Press, 1959.

White, Hayden. Metahistory. Baltimore and London: The Johns Hopkins University Press, 1973.

- - . Tropics of Discourse. Baltimore and London: The Johns Hopkins University Press, 1978.

- - . The Content of the Form. Baltimore and London: The Johns Hopkins University Press, 1987.

Woodward, Kenneth L. Makings saints: how the Catholic Church determines who becomes a saint, who doesn 't and why. New York: Simon and Schuster, 1990.

Woolf, Virginia. Orlando. Traducción de Jorge Luis Borges. Barcelona: Edhasa, 1986.

Zavala, Iris. "On the (Mis) - uses of the Post Modern: Hispanic Modernism Revisited" Postmodern Fiction in Europe and the Americas. Ed.Theo D'haen and Hans Berten. Amsterdam: Rodopi, 1988. 83-114. 


\section{VITA}

\section{FRANCISCO EDUARDO PORRATA}

1986

1988-present

1990

1991

1997-1998

2000

2000-2002
BA Spanish

Saint Thomas University

Miami, Florida

Spanish Teacher

Miami-Dade County Public Schools

Summer Language Institute for Spanish Teachers Centro de Estudios Norteamericanos Universidad Alcalá de Henares, Spain

MA Hispanic Studies

Florida International University

Teacher of the Year John G. Dupuis Elementary School

Miami-Dade County Public Schools

The Spain Language and Culture Program:

Children Literature Course

Universidad Complutense

Madrid, Spain

Doctoral Candidate in Spanish

Florida International University

\section{PUBLICATIONS AND PRESENTATIONS}

Porrata, Francisco E. et al. Arcoiris. Ed. Mario Hurtado. Miami: Rei America, 1994.

Porrata, Francisco E. "Las múltiples voces de Bajtín en El Portero: un carnaval areniano". Nation, Culture and Identity, Conference on Iberian and Iberian American Literatures. Florida International University/University of Miami. October, 1997. 
